\title{
ALASKA HIGHWAY CORRIDOR ELECTROMAGNETIC AND MAGNETIC AIRBORNE GEOPHYSICAL SURVEY DATA COMPILATION
}

L.E. Burns, G.R.C. Graham, A.M.E. Emond, Stevens Exploration Management Corp., and Fugro Airborne Surveys

Geophysical Report 2020-15

2020

STATE OF ALASKA

DEPARTMENT OF NATURAL RESOURCES

DIVISION OF GEOLOGICAL \& GEOPHYSICAL SURVEYS
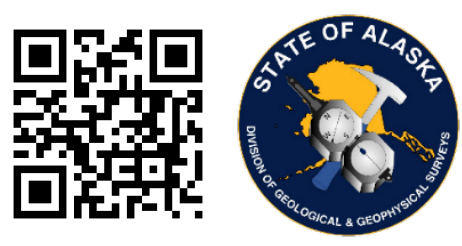


\title{
STATE OF ALASKA
}

Mike Dunleavy, Governor

\section{DEPARTMENT OF NATURAL RESOURCES}

Corri A. Feige, Commissioner

\section{DIVISION OF GEOLOGICAL \& GEOPHYSICAL SURVEYS}

Steve Masterman, State Geologist \& Director

Publications produced by the Division of Geological \& Geophysical Surveys are available to download from the DGGS website (dggs.alaska.gov). Publications on hard-copy or digital media can be examined or purchased in the Fairbanks office:

\author{
Alaska Division of Geological \& Geophysical Surveys (DGGS) \\ 3354 College Road | Fairbanks, Alaska 99709-3707 \\ Phone: 907.451.5010 | Fax 907.451.5050 \\ dggspubs@alaska.gov $\mid$ dggs.alaska.gov
}

DGGS publications are also available at:

Alaska State Library, Historical

Collections \& Talking Book Center

395 Whittier Street

Juneau, Alaska 99801

Alaska Resource Library and

Information Services (ARLIS)

3150 C Street, Suite 100

Anchorage, Alaska 99503

\section{Suggested citation:}

Burns, L.E., Graham, G.E., Emond, A.M., Stevens Exploration Management Corp., and Fugro Airborne Surveys, 2020, Alaska Highway corridor electromagnetic and magnetic airborne geophysical survey data compilation: Alaska Division of Geological \& Geophysical Surveys Geophysical Report 2020-15. http://doi.org/10.14509/30462
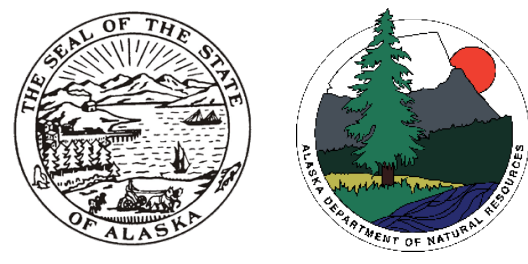


\section{ALASKA HIGHWAY CORRIDOR ELECTROMAGNETIC AND MAGNETIC AIRBORNE GEOPHYSICAL SURVEY DATA \\ L.E. Burns ', G.R.C. Graham 1', A.M.E. Emond', Stevens Exploration Management Corp., and Fugro Airborne Surveys}

\section{ABSTRACT}

The Alaska Highway corridor electromagnetic and magnetic airborne geophysical survey is located in interior Alaska along the Alaska Highway corridor, from Delta Junction to the Canadian border. Frequency domain electromagnetic and magnetic data were collected with the RESOLVE system from August 27th, 2005 to January 16th, 2006. A total of 22,948.5 line kilometers were collected covering 8117.5 square kilometers. Line spacing was 400 meters $(\mathrm{m})$. Data were collected $30 \mathrm{~m}$ above the ground surface from a helicopter towed sensor platform ("bird") on a $30 \mathrm{~m}$ long line.

\section{PURPOSE}

This airborne geophysical survey was acquired to gather geologic information to assess the geologic hazards, construction materials, and mineral potential on the Alaska Highway corridor in east-central Alaska. The geophysical information acquired helps provide information on conductive overburden, potential construction materials, permafrost, fractures and faulting, and other information. Prospects within the survey area include Road Metal, Triple Z (ASARCO), and Discovery Zone. In addition, these data are to assist geologic mapping in the region.

\section{SURVEY OVERVIEW DESCRIPTION}

This document provides an overview of the survey and includes text and figures of select primary and derivative products of this survey. A table of digital data packages available for download is provided to assist users in data selection. For reference, a catalog of the available maps is presented in reduced resolution. Please consult the metadata, project report, and digital data packages for more information and data.

\section{ACKNOWLEDGMENTS}

Funding was provided by the Alaska State Legislature.

\footnotetext{
${ }^{1}$ Alaska Division of Geological \& Geophysical Surveys, 3354 College Road, Fairbanks, Alaska 99709-3707
} 


\begin{tabular}{|c|c|c|}
\hline Data Type & Provider & Description \\
\hline ascii_data & contractor & ASCII format line data, other ASCII data \\
\hline databases_geosoft & contractor & $\begin{array}{l}\text { Geosoft format database of final line data, other Geosoft format } \\
\text { databases }\end{array}$ \\
\hline documents & $\begin{array}{l}\text { contractor and } \\
\text { DGGS }\end{array}$ & $\begin{array}{l}\text { Project and field reports, survey background information, } \\
\text { gridded data explanations, other documentation }\end{array}$ \\
\hline grids_ermapper & $\begin{array}{l}\text { contractor and } \\
\text { DGGS }\end{array}$ & Geographically registered gridded data, ER Mapper ERS format \\
\hline grids_geosoft & $\begin{array}{l}\text { contractor and } \\
\text { DGGS }\end{array}$ & $\begin{array}{l}\text { Geosoft-format grids, these grids can be viewed in ESRI ArcMap } \\
\text { using a free plugin from Geosoft or the free viewer available } \\
\text { from Geosoft }\end{array}$ \\
\hline images_registered & DGGS & GeoTiff format images of gridded data \\
\hline $\mathrm{kmz}$ & DGGS & $\begin{array}{l}\text { keyhole markup language }(\mathrm{kml}) \mathrm{kmz} \text { archive files of project } \\
\text { data. Viewable in Google Earth and other compatible programs }\end{array}$ \\
\hline maps_pdf_format & $\begin{array}{l}\text { contractor and } \\
\text { DGGS }\end{array}$ & $\begin{array}{l}\text { Printable maps in pdf format. Includes a geographically } \\
\text { registered pdf (GeoPDF) for use with mobile devices such as } \\
\text { GPS enabled smartphones and tablets, other devices, and } \\
\text { programs }\end{array}$ \\
\hline maps_prn_format & contractor & Printable maps in HPGL/2 printer file format with extension .prn \\
\hline profiles_stacked & contractor & $\begin{array}{l}\text { Distance-based profiles of the digitally recorded geophysical } \\
\text { data are generated and plotted at an appropriate scale. The } \\
\text { profiles display electromagnetic anomalies with their } \\
\text { respective interpretive symbols. Printable in pdf format }\end{array}$ \\
\hline Resistivity_models & $\begin{array}{l}\text { contractor and } \\
\text { DGGS }\end{array}$ & $\begin{array}{l}\text { ACSII CSV format resistivity models in project coordinates with } \\
\text { data field guides, figures and supporting documentation in } \\
\text { ASCll text, PDF, KML, and/or other formats }\end{array}$ \\
\hline vector_data & $\begin{array}{l}\text { contractor and } \\
\text { DGGS }\end{array}$ & $\begin{array}{l}\text { Line path, data contours, and survey boundary in ESRI shapefile } \\
\text { (SHP) format, ESRI Geodatabase format, and/or AutoCAD dxf } \\
\text { format }\end{array}$ \\
\hline video_flightpath & contractor & Survey flight path downward facing video \\
\hline
\end{tabular}




\section{REFERENCES}

Akima, H., 1970, A new method of interpolation and smooth curve fitting based on local procedures: Journal of the Association of Computing Machinery, v. 17, n. 4, p. 589-602.

Burns, L.E., Fugro Airborne Surveys Corp., and Stevens Exploration Management Corp., 2006, Line, grid, and vector data, and plot files for the airborne geophysical survey of the Alaska Highway corridor, eastcentral Alaska: Alaska Division of Geological \& Geophysical Surveys Geophysical Report 2006-6, 1 DVD. http://doi.org/10.14509/14864

Burns, L.E., Fugro Airborne Surveys Corp., and Stevens Exploration Management Corp., 2008, Final processed database for the airborne geophysical surveys of the Alaska Highway corridor, east-central Alaska: Alaska Division of Geological \& Geophysical Surveys Geophysical Report 2006-8, 1 DVD. http://doi.org/10.14509/17761 


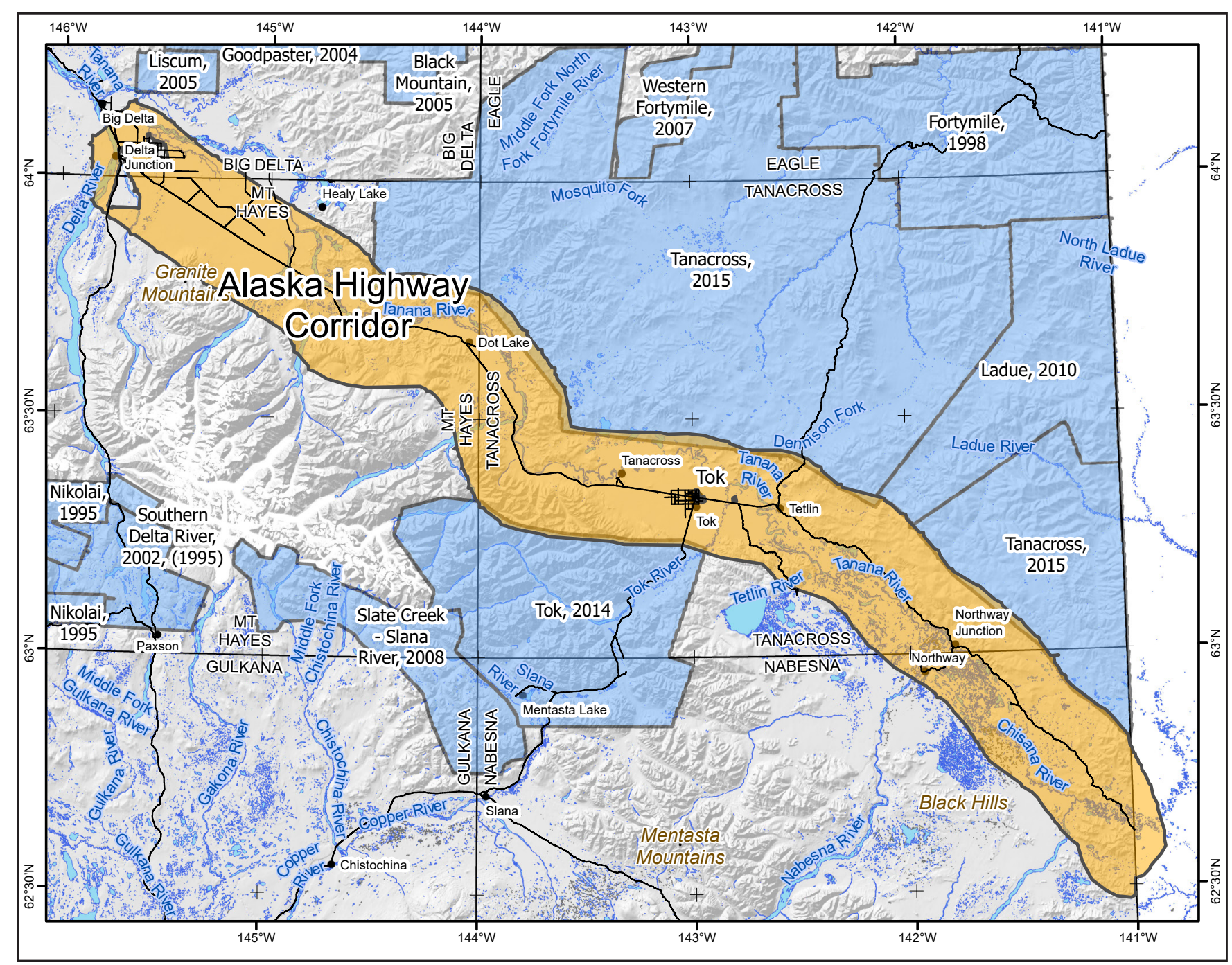

Figure 1. Alaska Highway Corridor magnetic and electromagnetic airborne geophysical survey location shown in eastern interior Alaska (inset). Alaska Highway Corridor survey area shown with landmarks, relevant 1:250,000-scale quadrangle boundaries, mountain ranges, rivers, and elevation hillshade.

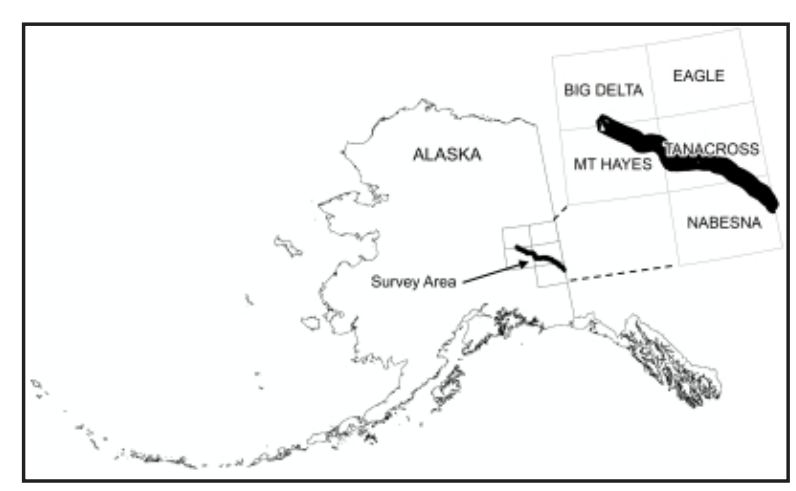




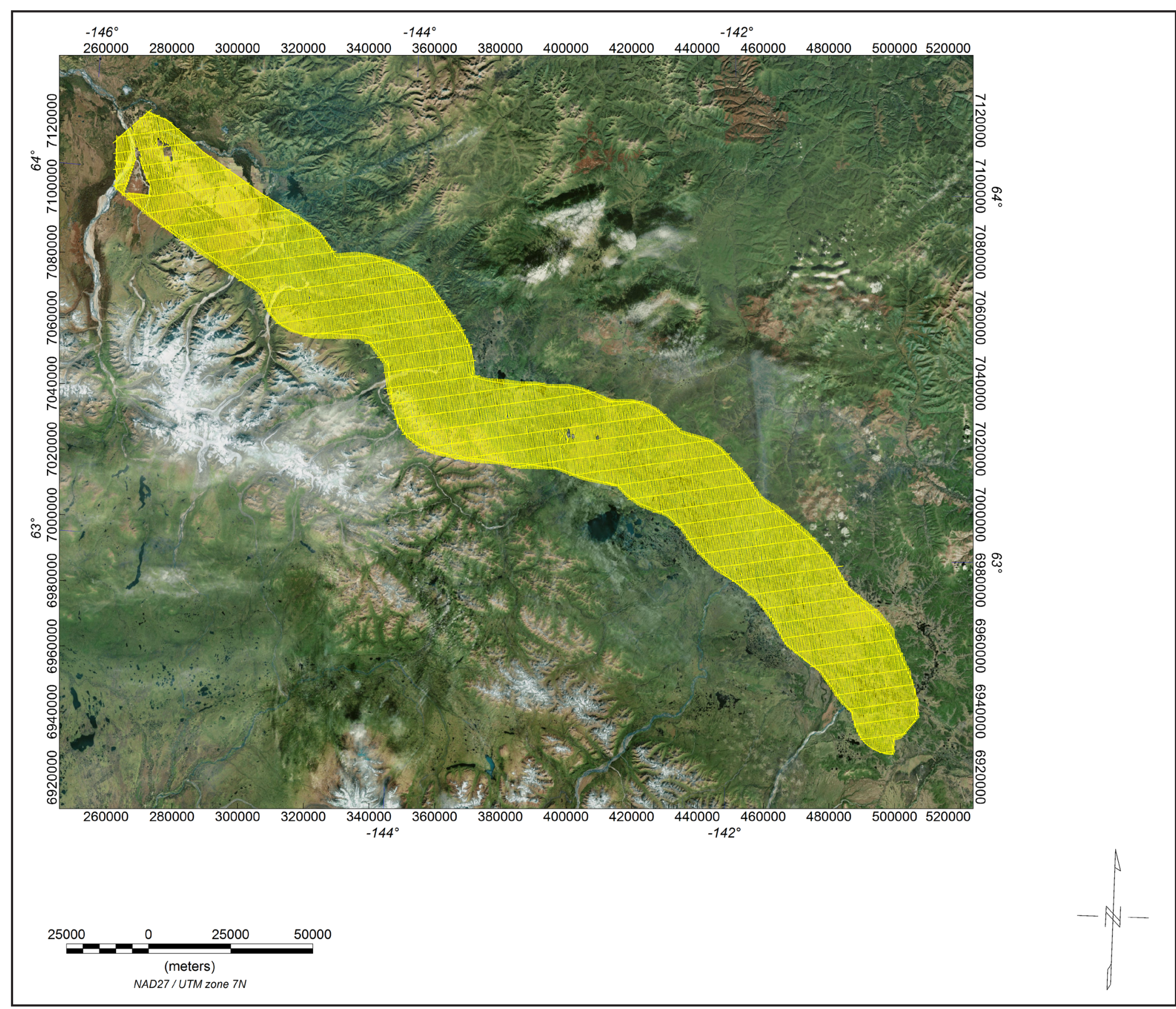

Figure 2. Flight path with orthometric image. 


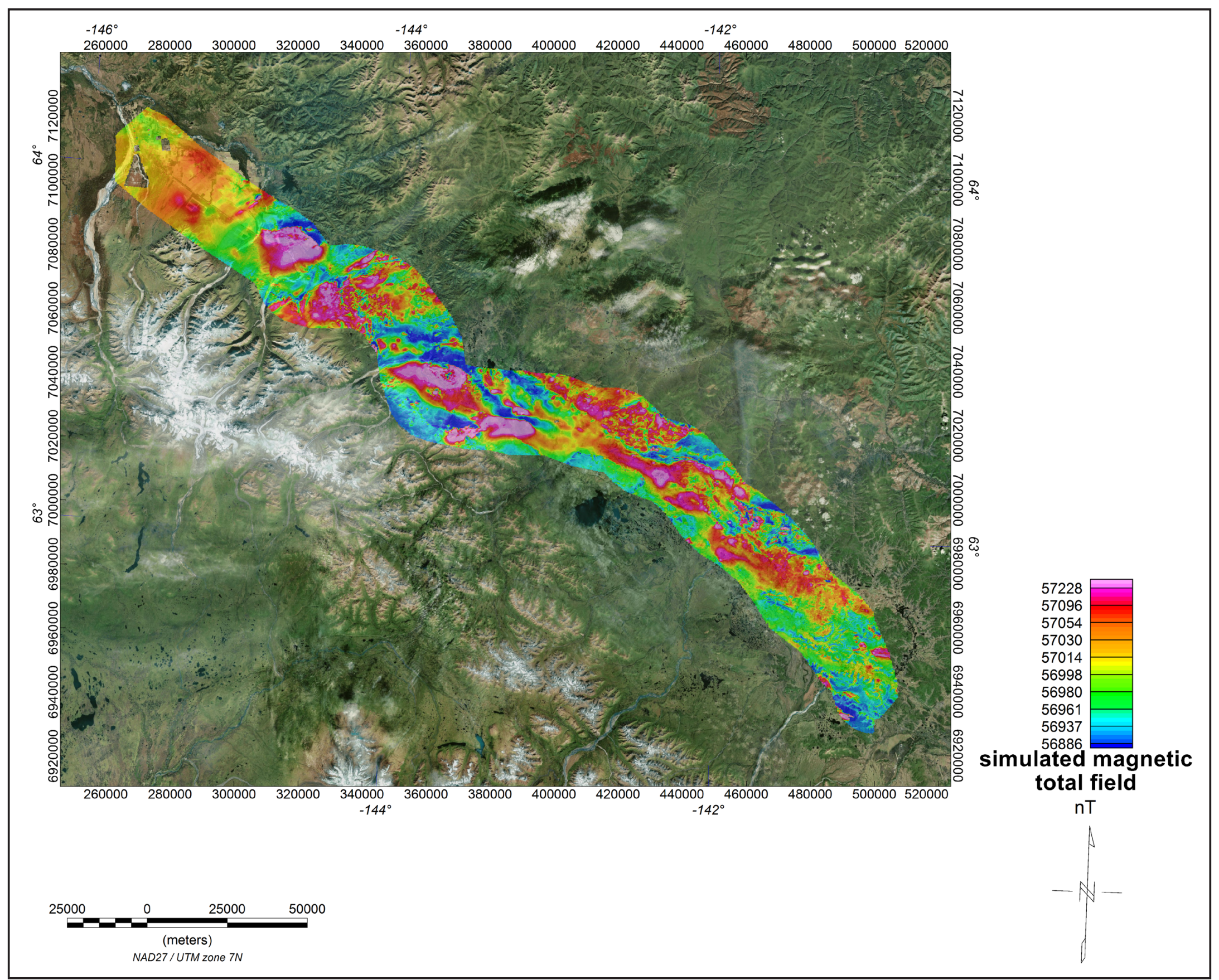

Figure 3. Simulated magnetic total field grid with orthometric image. 


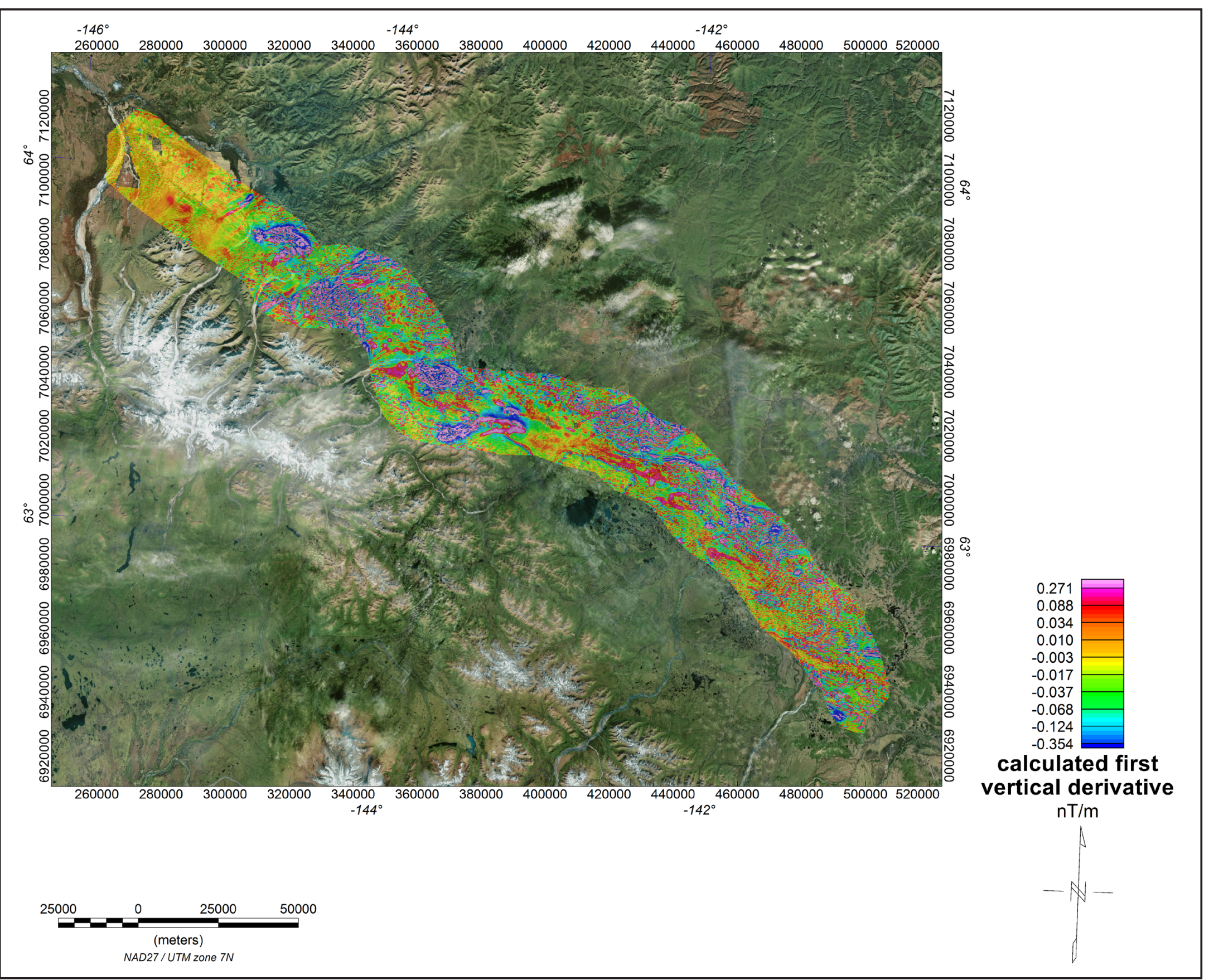

Figure 4. Calculated first vertical derivative grid with orthometric image. The first vertical derivative grid was calculated from the diurnally-corrected, IGRF-corrected total magnetic field grid using a FFT base frequency domain filtering algorithm. The resulting first vertical derivative grid provides better definition and resolution of near- surface magnetic units and helps to identify weak magnetic features that may not be evident on the total field data. 


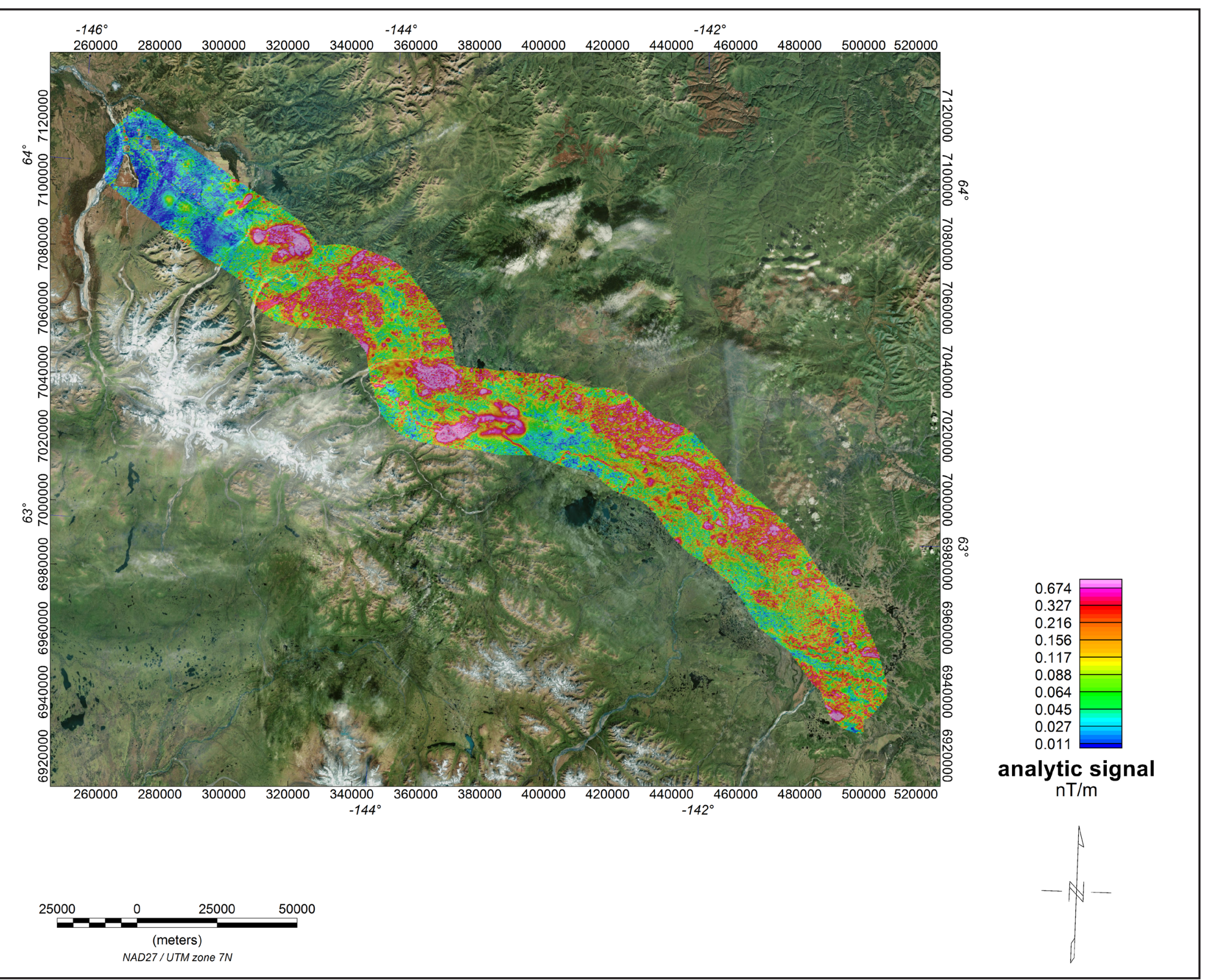

Figure 5. Analytic signal grid with orthometric image. Analytic signal is the total amplitude of all directions of magnetic gradient calculated from the sum of the squares of the three orthogonal gradients. Mapped highs in the calculated analytic signal of magnetic parameter locate the anomalous source body edges and corners (such as contacts, fault/shear zones, etc.). Analytic signal maxima are located directly over faults and contacts, regardless of structural dip, and independent of the direction of the induced and/or remanent magnetizations. 


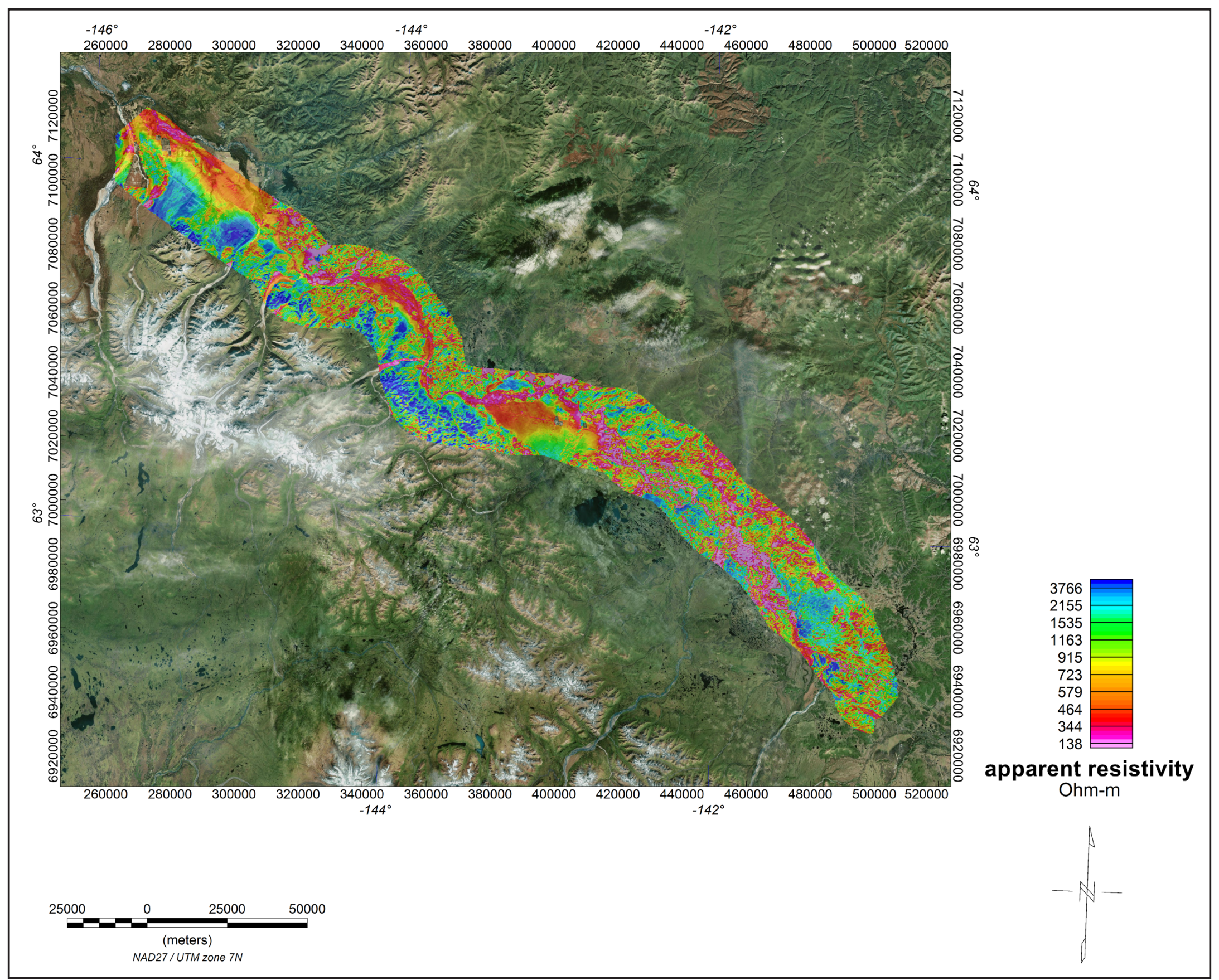

Figure 6. 140,000 Hz apparent resistivity grid with orthometric image. 


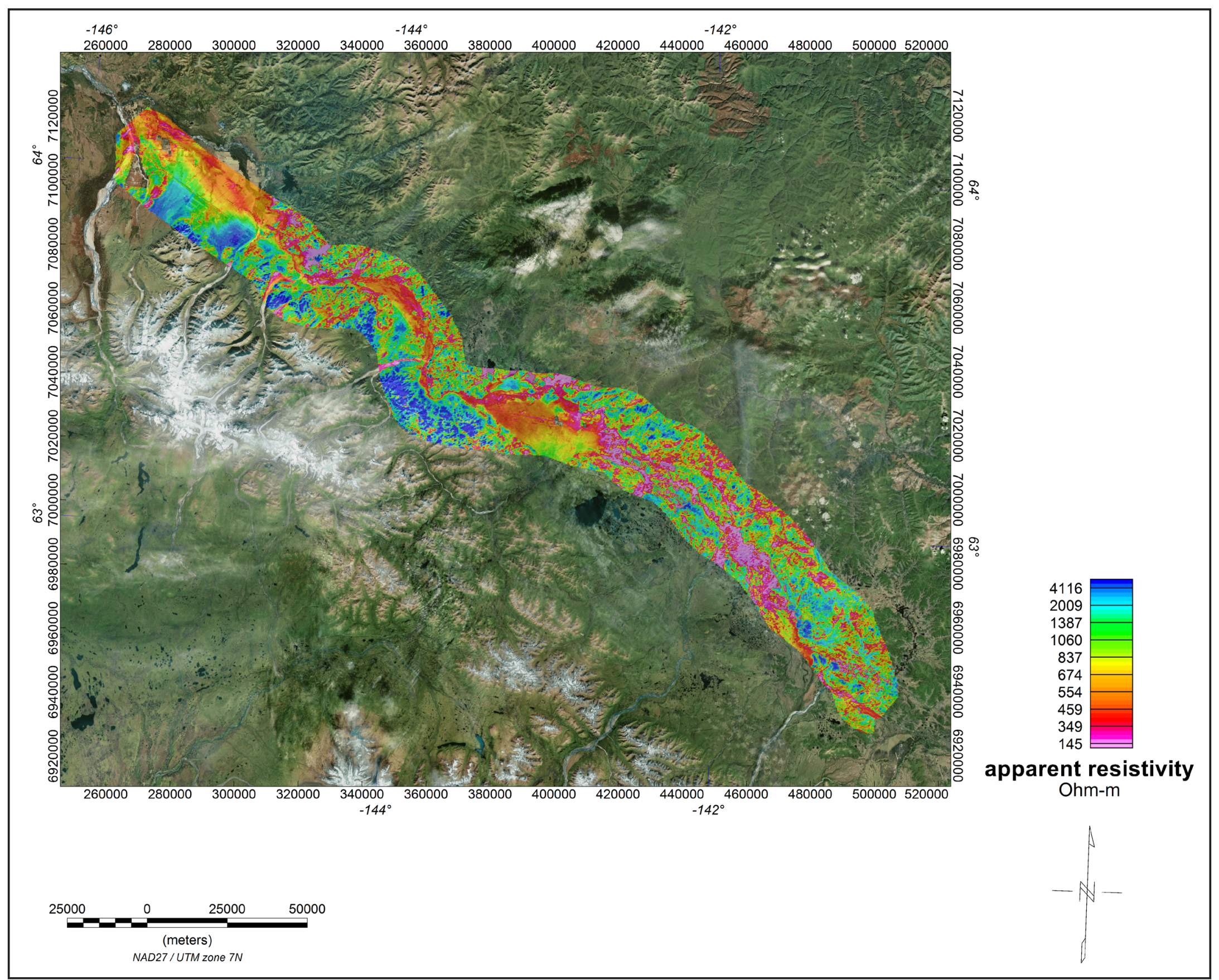

Figure 7. 40,000 Hz apparent resistivity grid with orthometric image. 


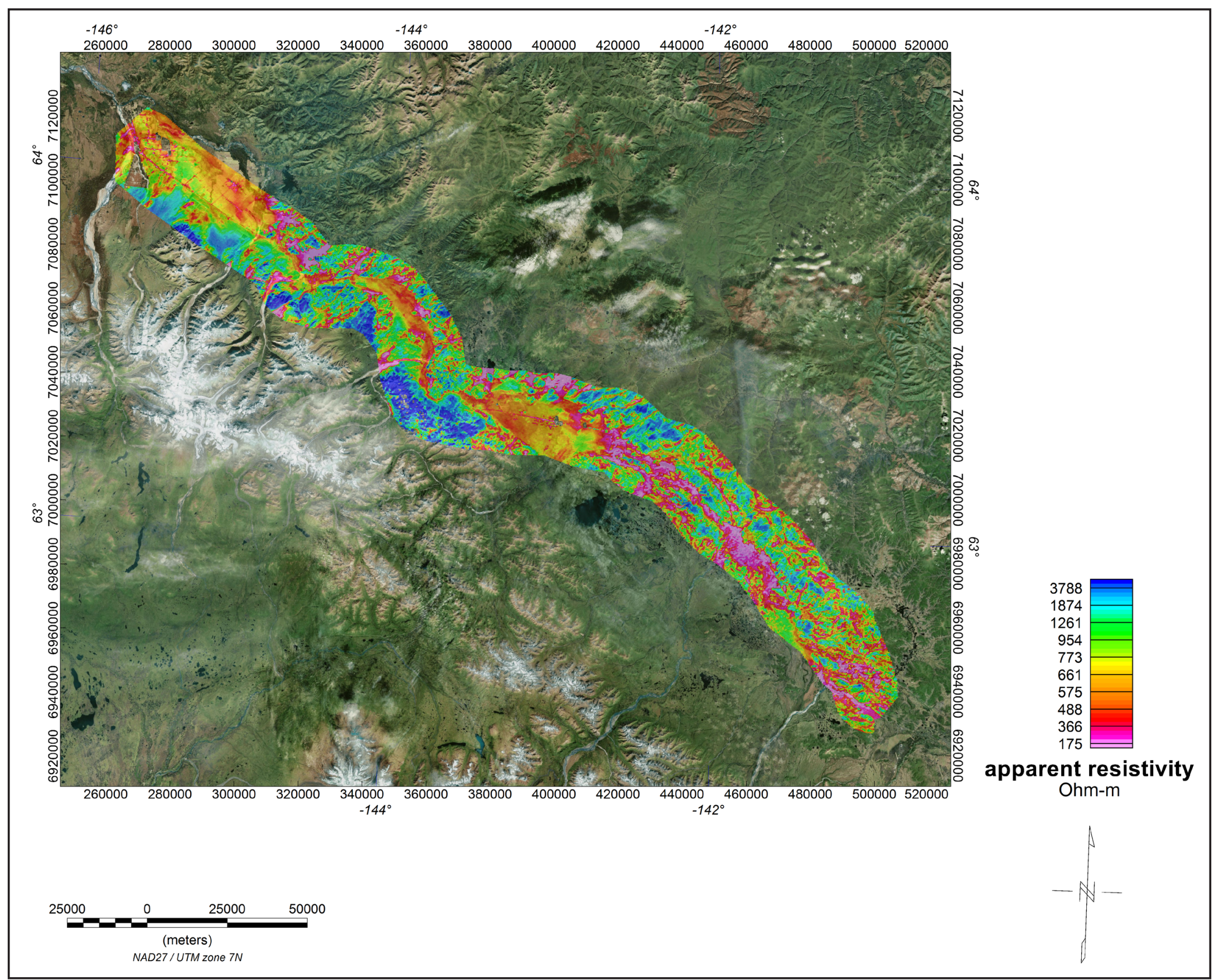

Figure 8. 8,200 Hz apparent resistivity grid with orthometric image. 


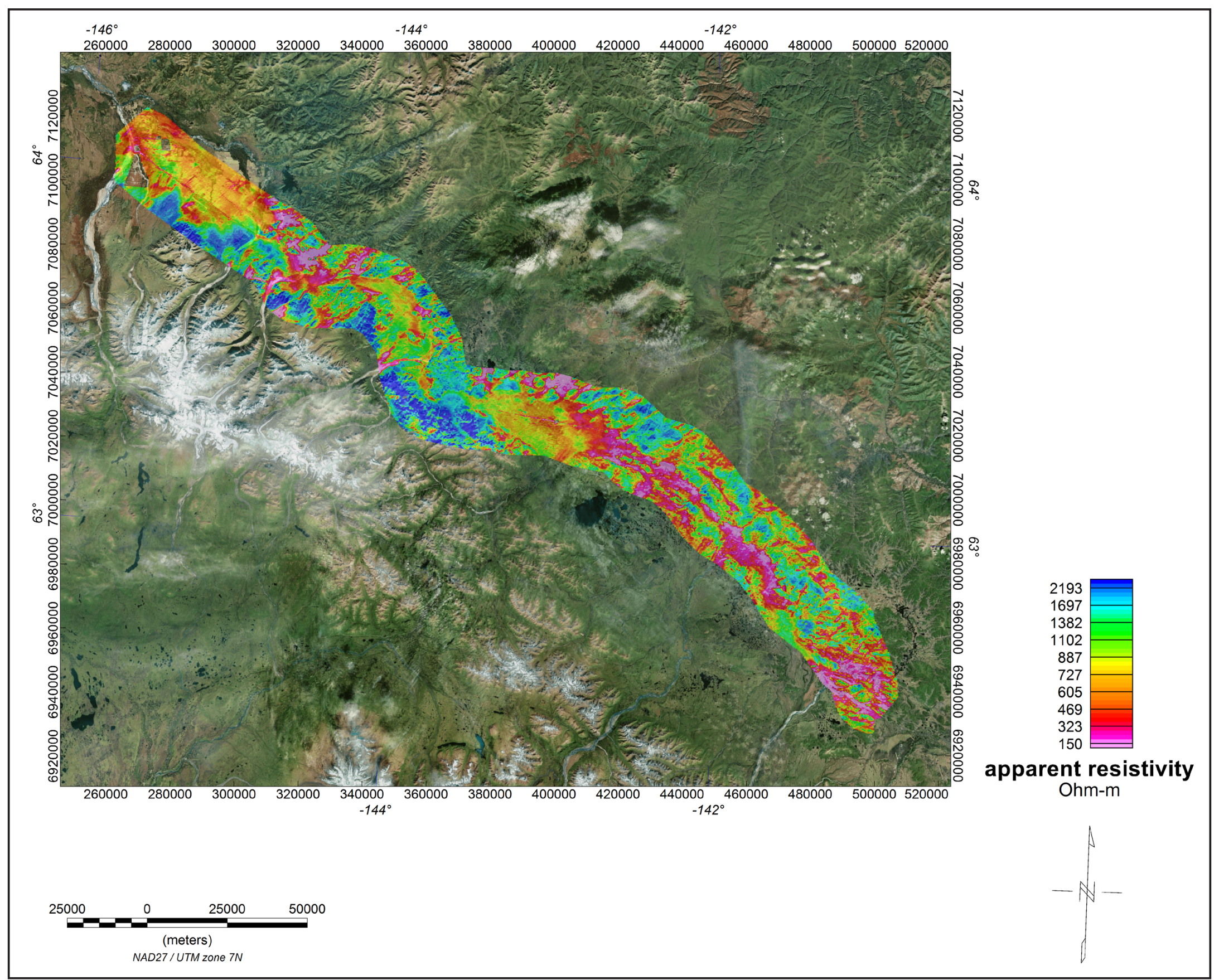

Figure 9.3,300 Hz apparent resistivity grid with orthometric image. 


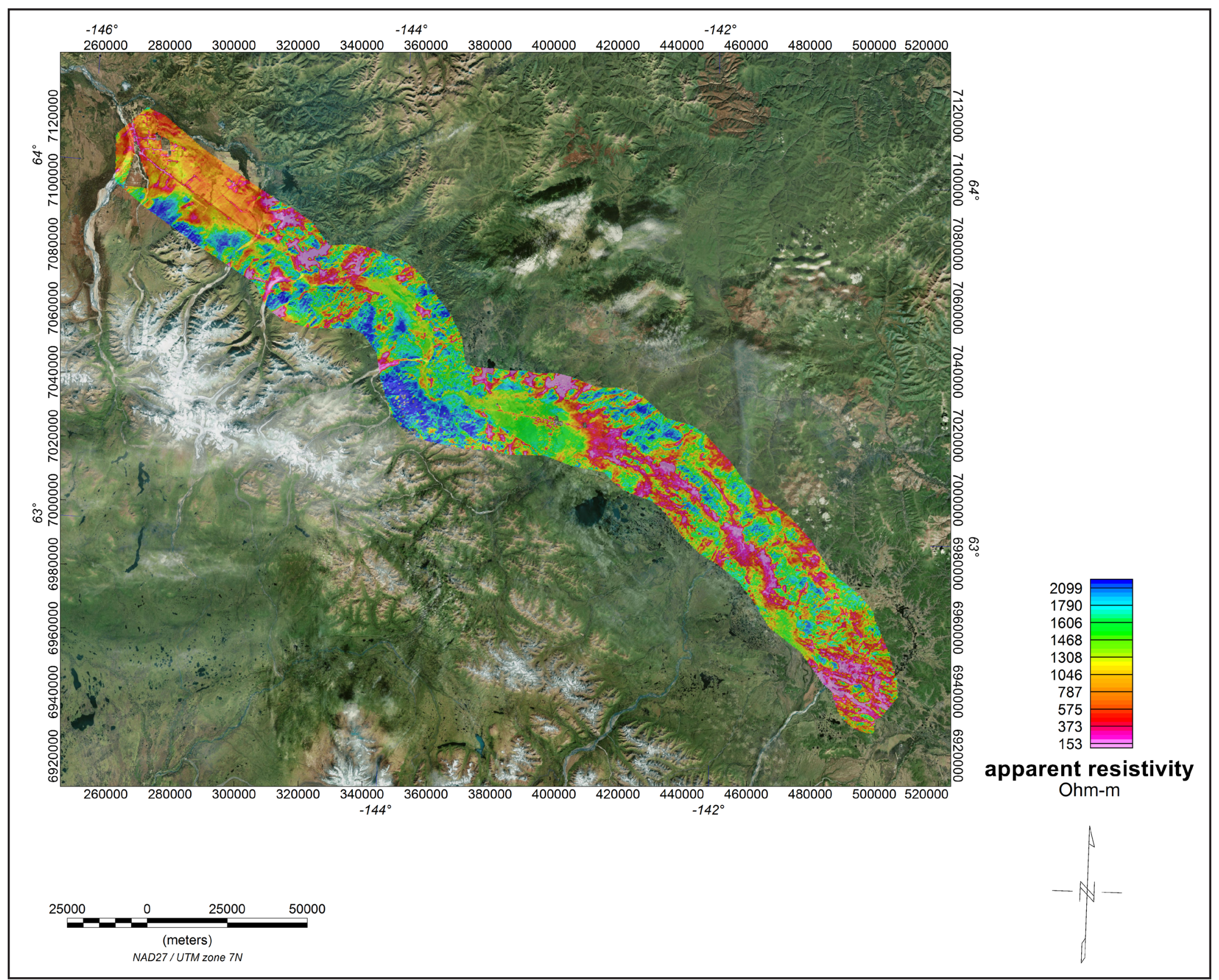

Figure 10. 1,800 Hz apparent resistivity grid with orthometric image. 


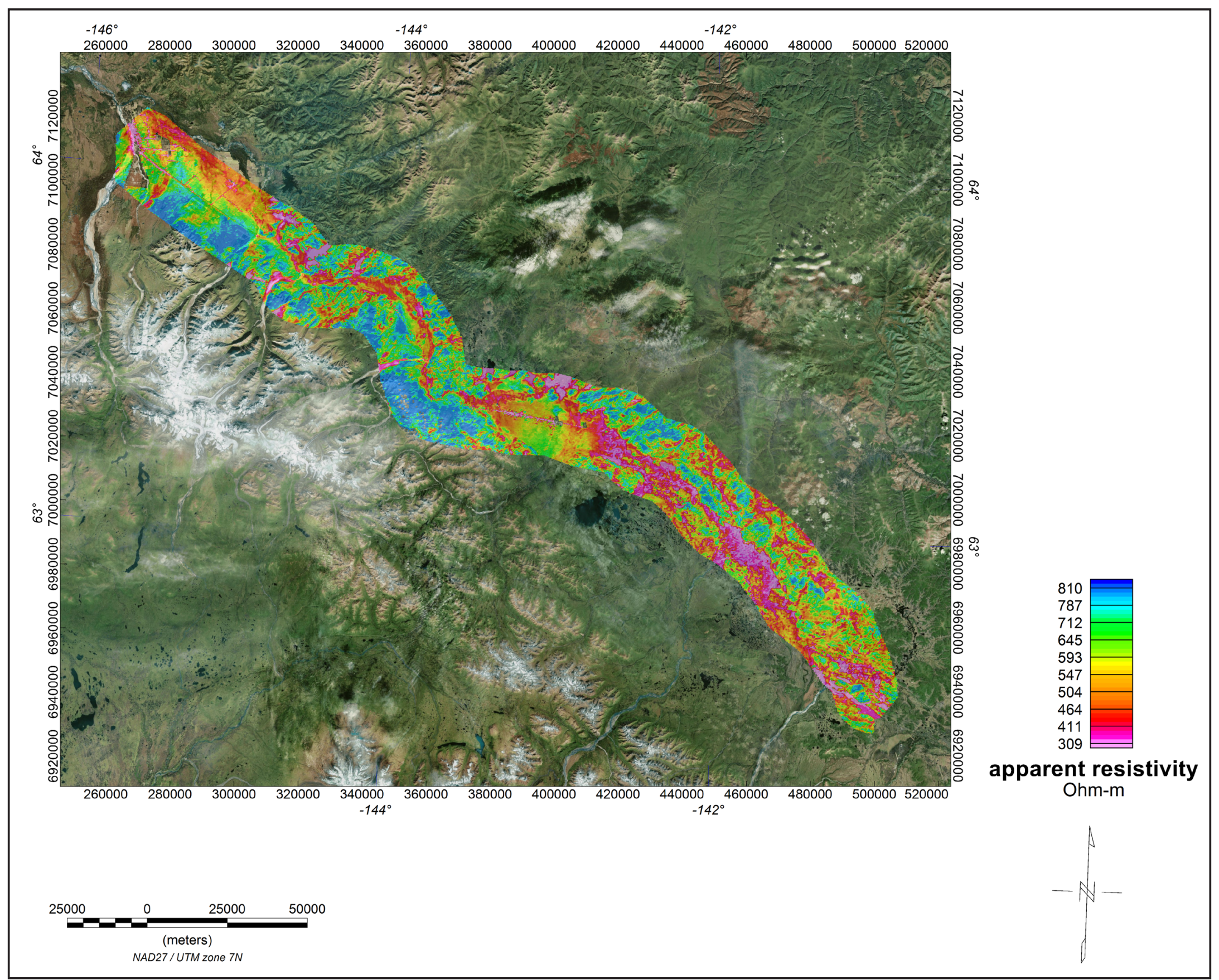

Figure 11. $400 \mathrm{~Hz}$ apparent resistivity grid with orthometric image. 


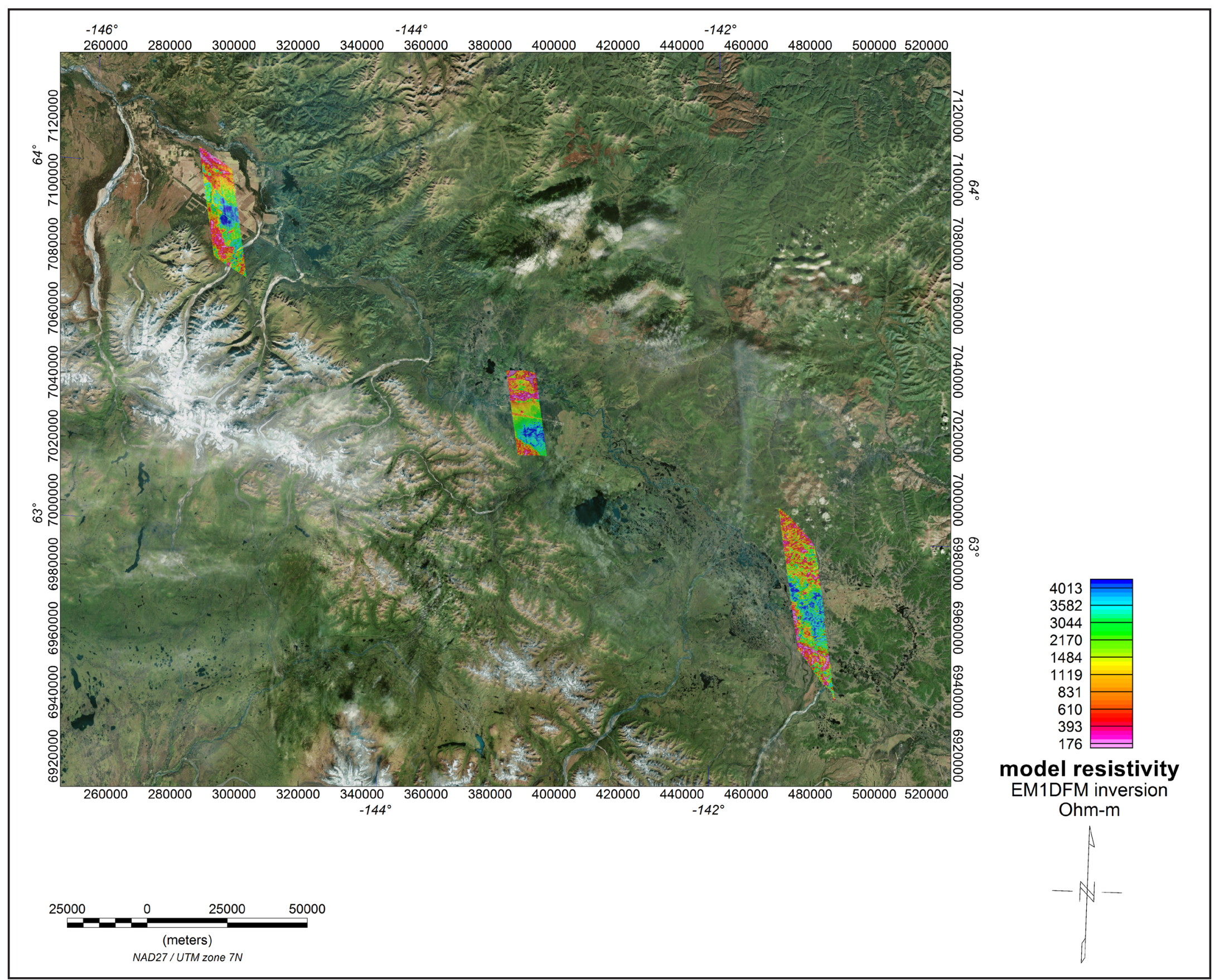

Figure 12. Depth slice grid, EM1DFM inversion model resistivity 4 meters below ground surface with orthometric image. Three resistivity models: Differential, Sengpiel, and EM1DFM were produced for this project. 




Figure 13. Depth slice grid, EM1DFM inversion model resistivity 40 meters below ground surface with orthometric image. Three resistivity models: Differential, Sengpiel, and EM1DFM were produced for this project. 
Table 1. Copies of the following maps are included at the end of this booklet. The low-resolution, page-size maps included in this booklet are intended to be used as a search tool and

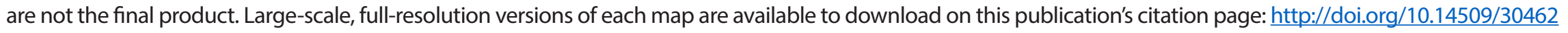

\begin{tabular}{|l|l|}
\hline \multicolumn{1}{|c|}{ Map Title } & \multicolumn{1}{|c|}{ Description } \\
\hline alaska_highway_corridor_res140khz_topo_map & $140,000 \mathrm{~Hz}$ apparent resistivity grid with topographic base map \\
\hline alaska_highway_corridor_res40khz_topo_map & $40,000 \mathrm{~Hz}$ apparent resistivity grid with topographic base map \\
\hline alaska_highway_corridor_res8200hz_topo_map & $8,200 \mathrm{~Hz}$ apparent resistivity grid with topographic base map \\
\hline alaska_highway_corridor_res3300hz_topo_map & $3,300 \mathrm{~Hz}$ apparent resistivity grid with topographic base map \\
\hline alaska_highway_corridor_res1800hz_topo_map & $1,800 \mathrm{~Hz}$ apparent resistivity grid with topographic base map \\
\hline alaska_highway_corridor_res400hz_topo_map & $400 \mathrm{~Hz}$ apparent resistivity grid with topographic base map \\
\hline alaska_highway_corridor_magtf_topo_map & total magnetic total field grid with topographic base map \\
\hline alaska_highway_corridor_calculated1vd_topo_map & calculated first vertical derivative of the magnetic field grid with topographic base map \\
\hline alaska_highway_corridor_interpretation_map & interpretation based on geophysical data \\
\hline
\end{tabular}




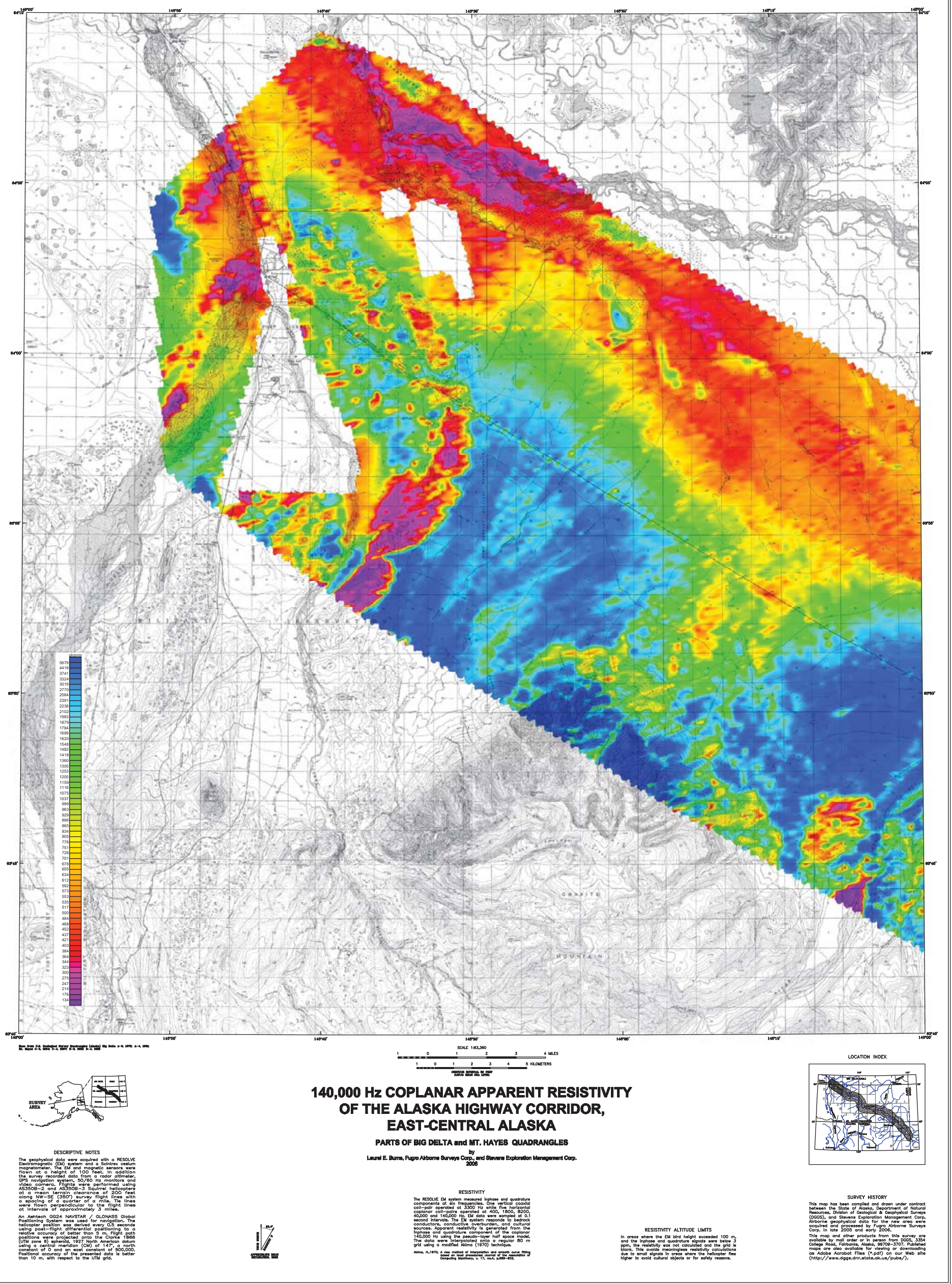




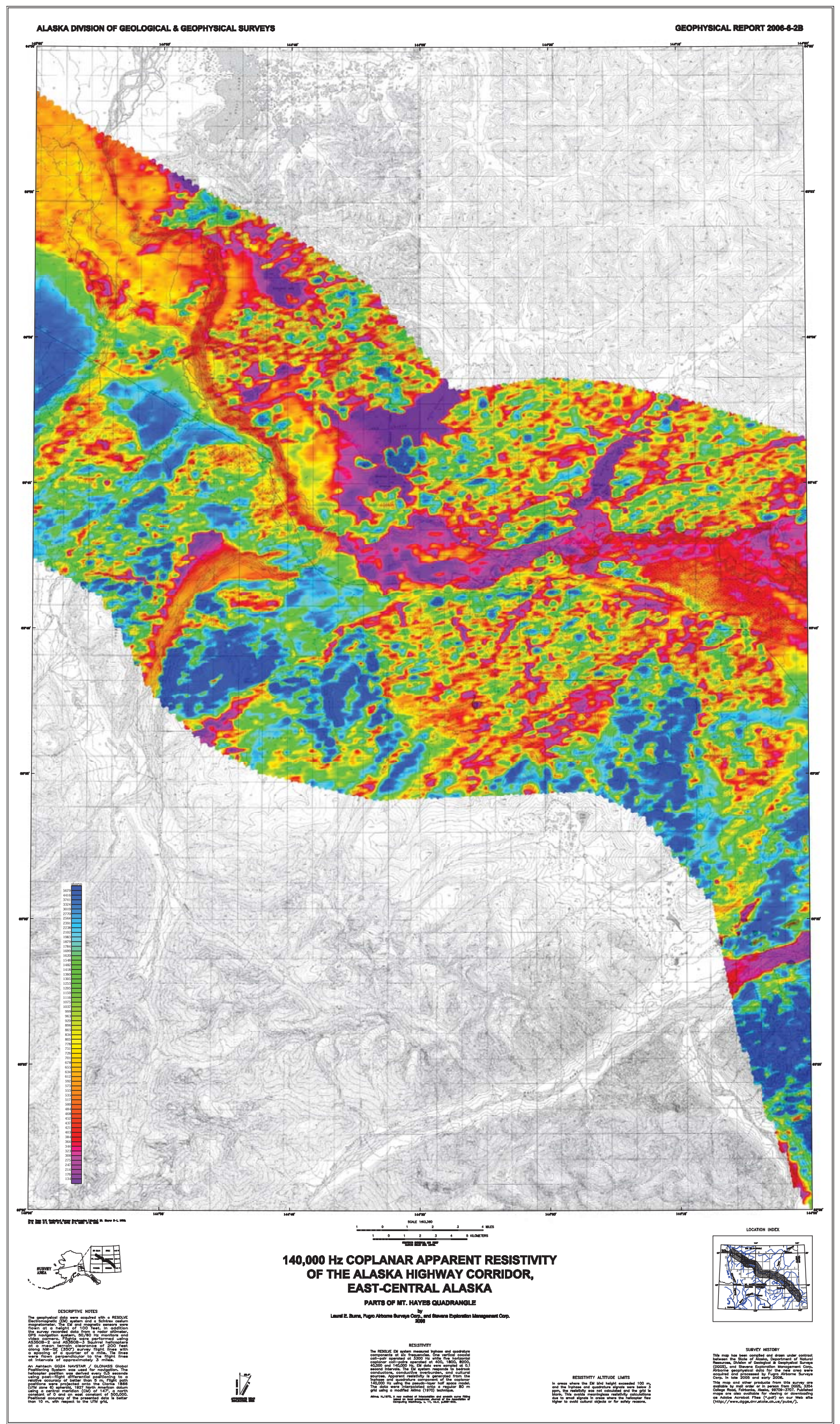




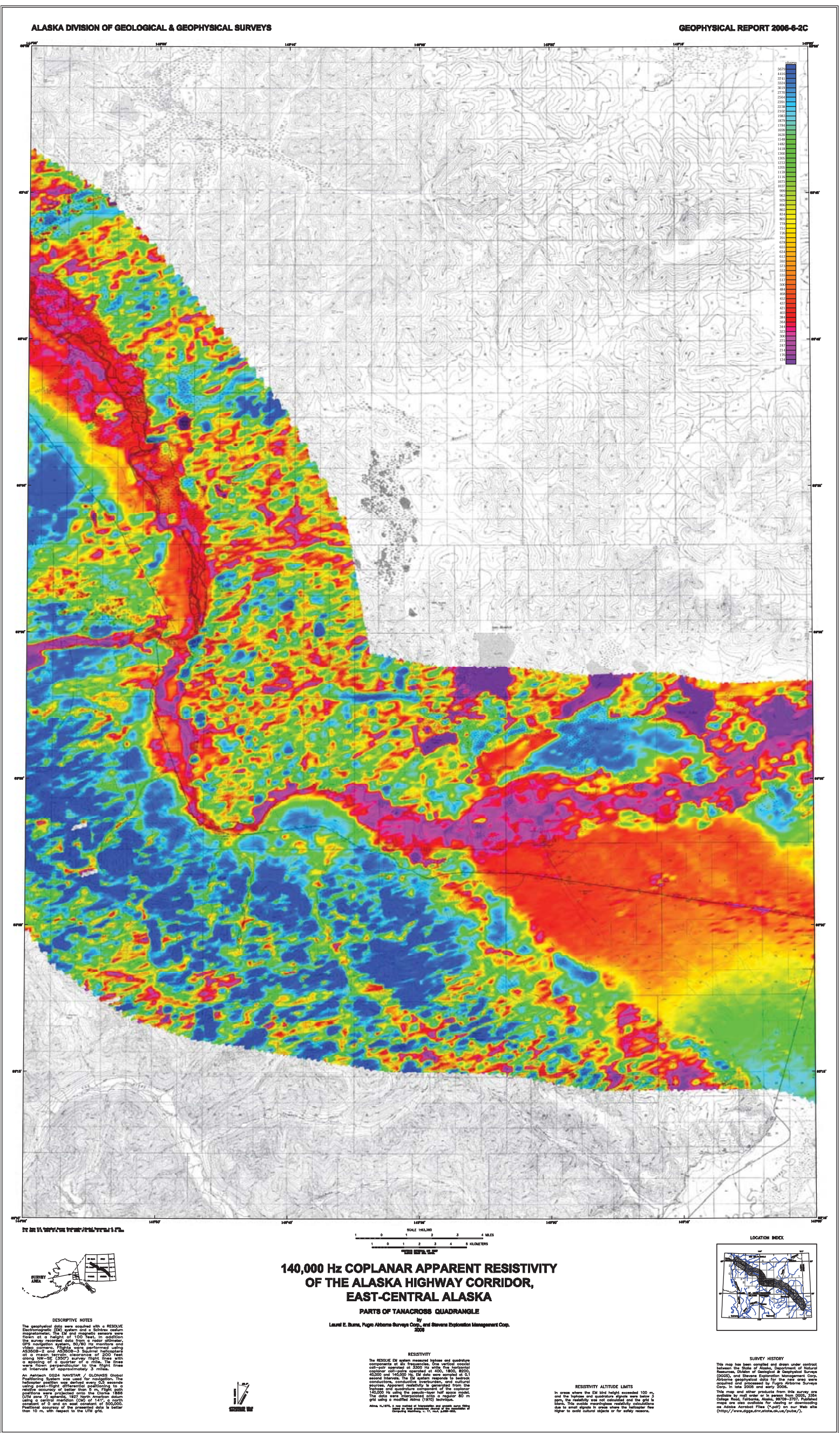




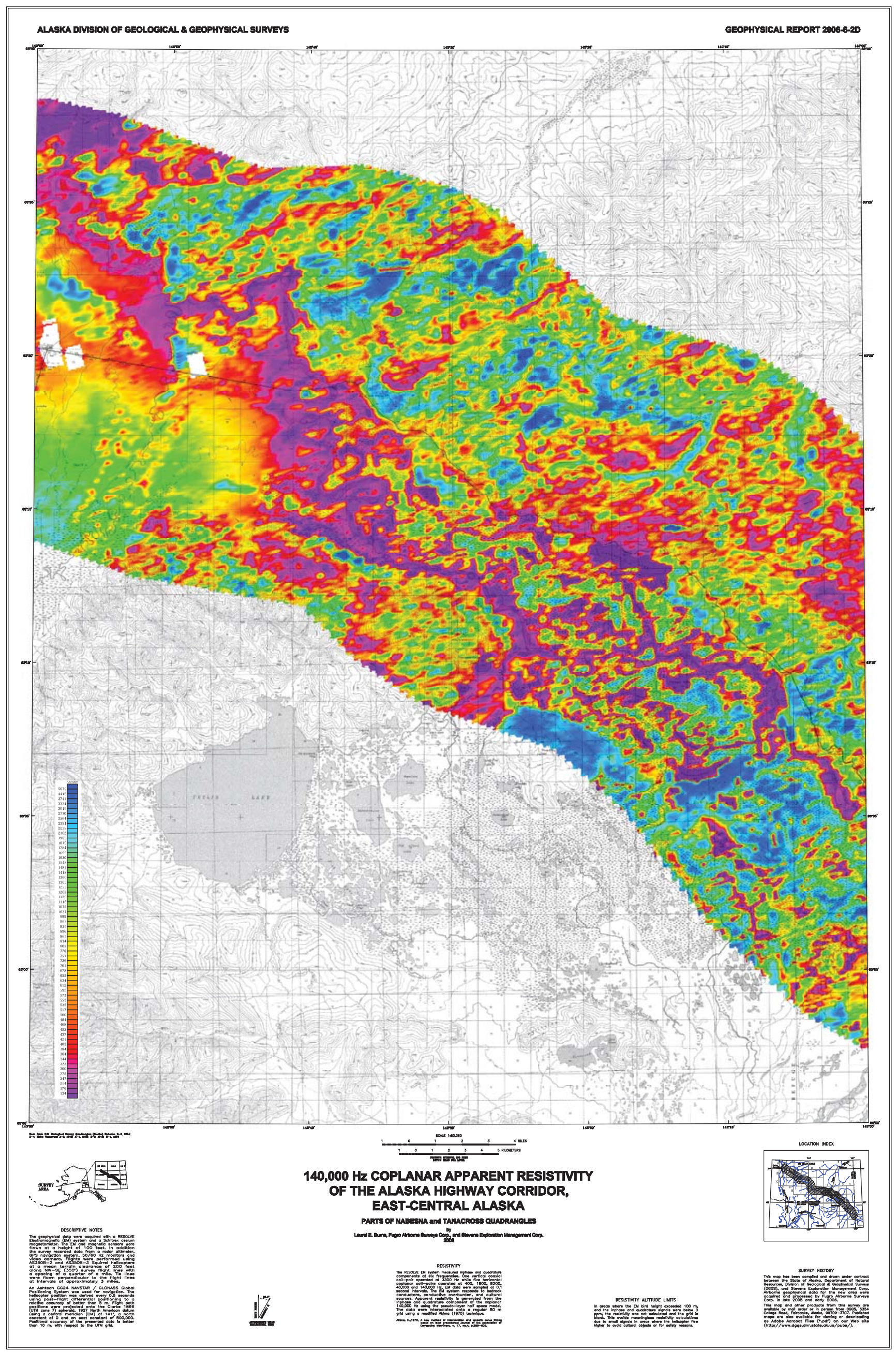




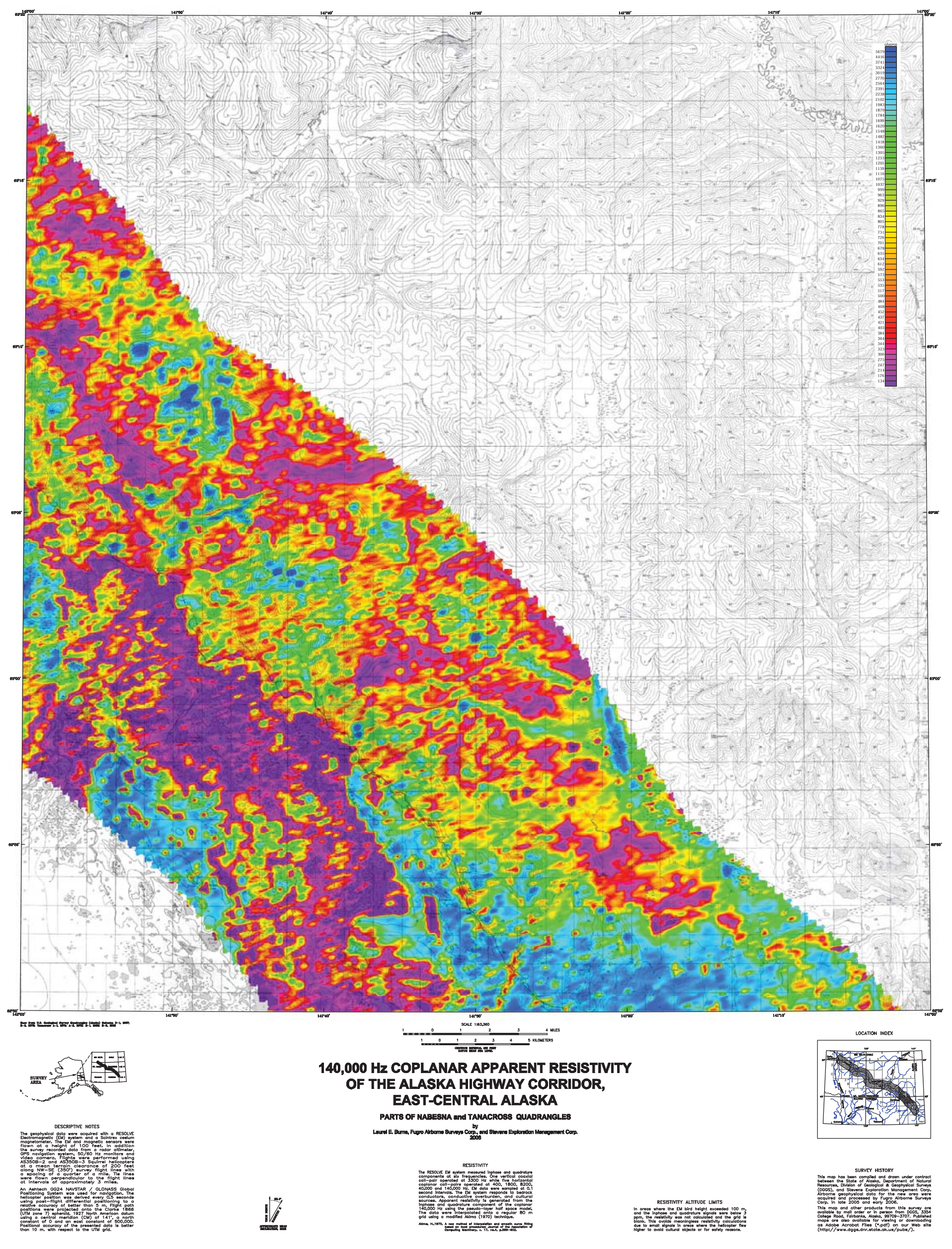




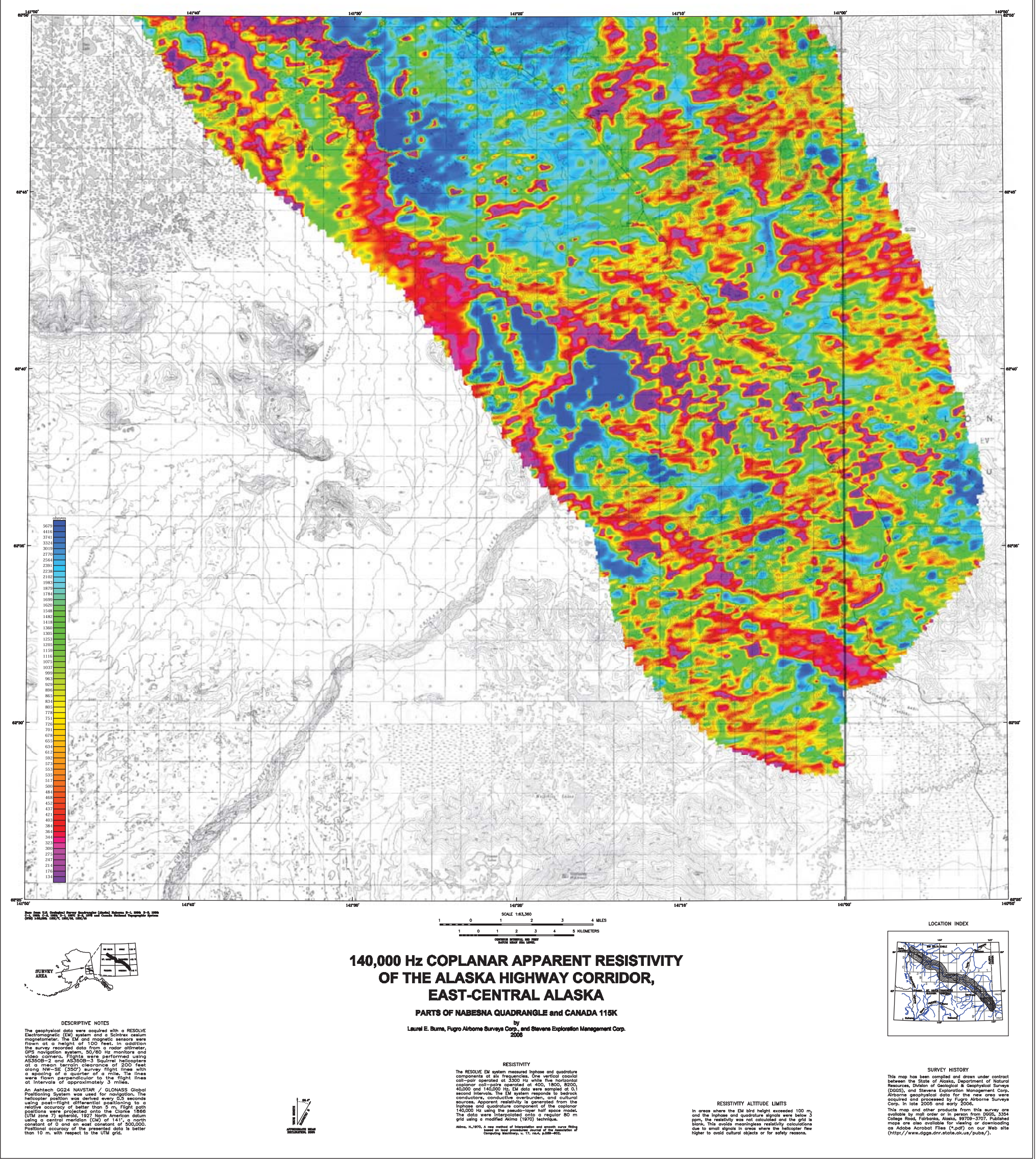




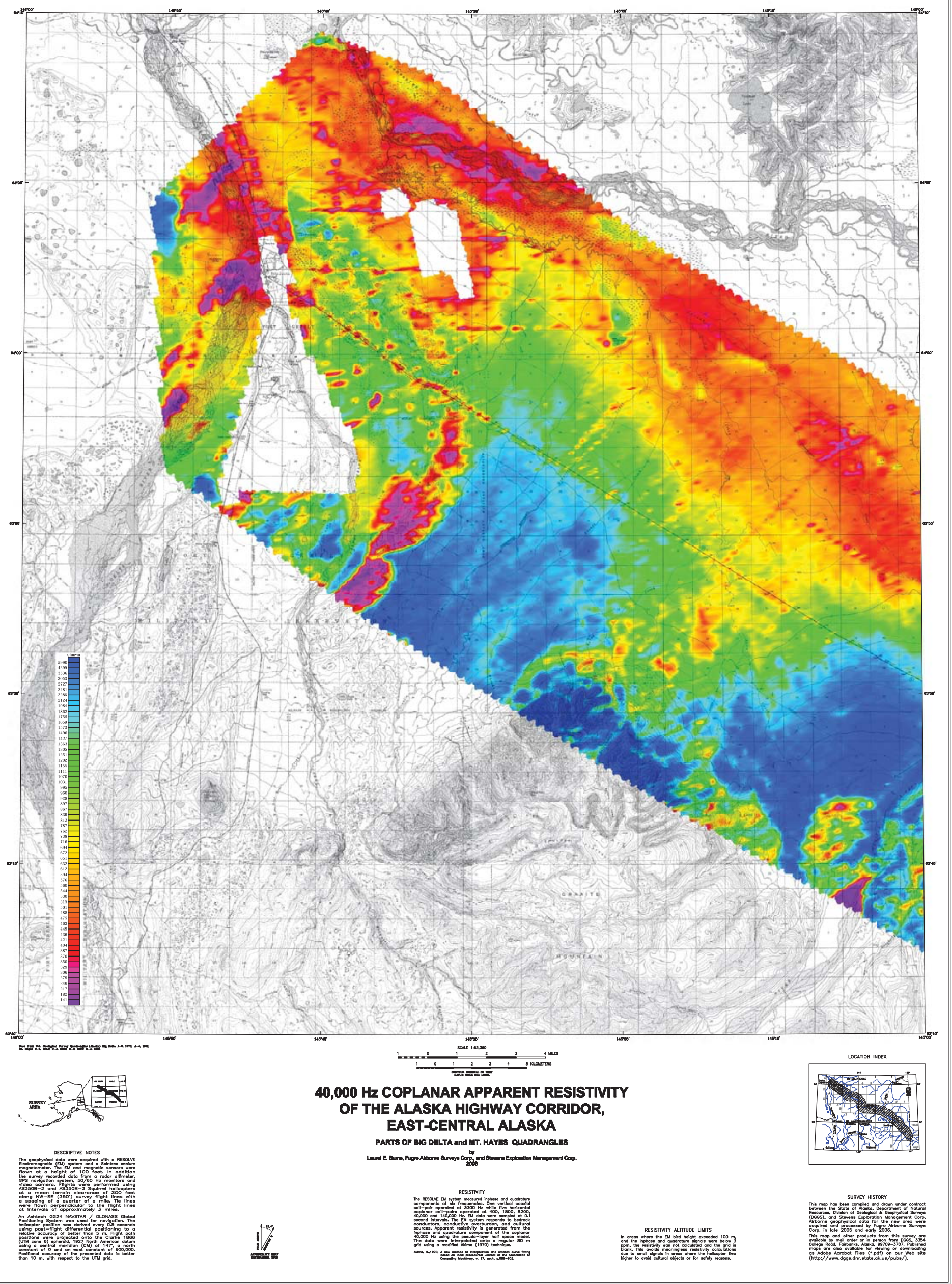




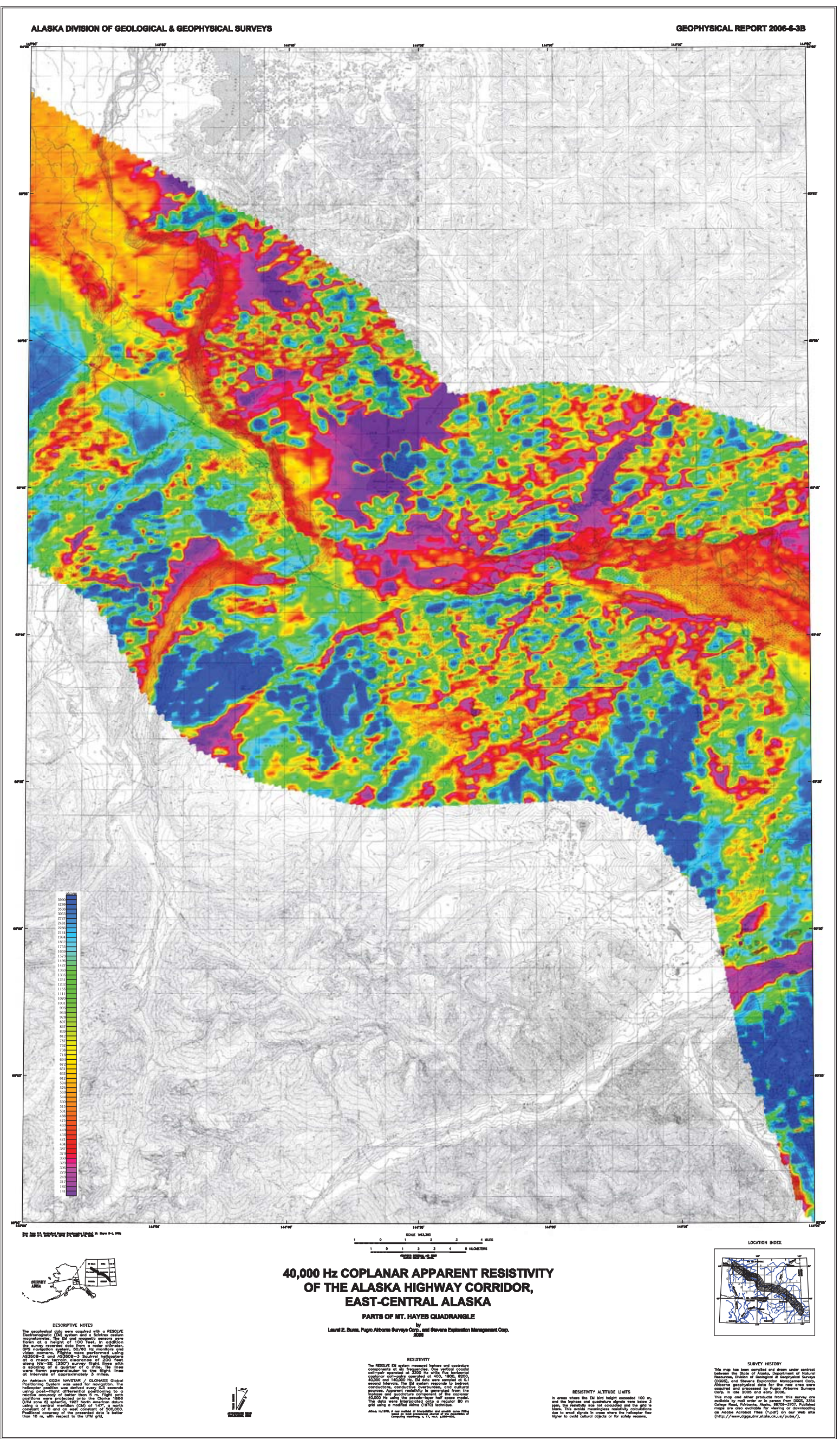




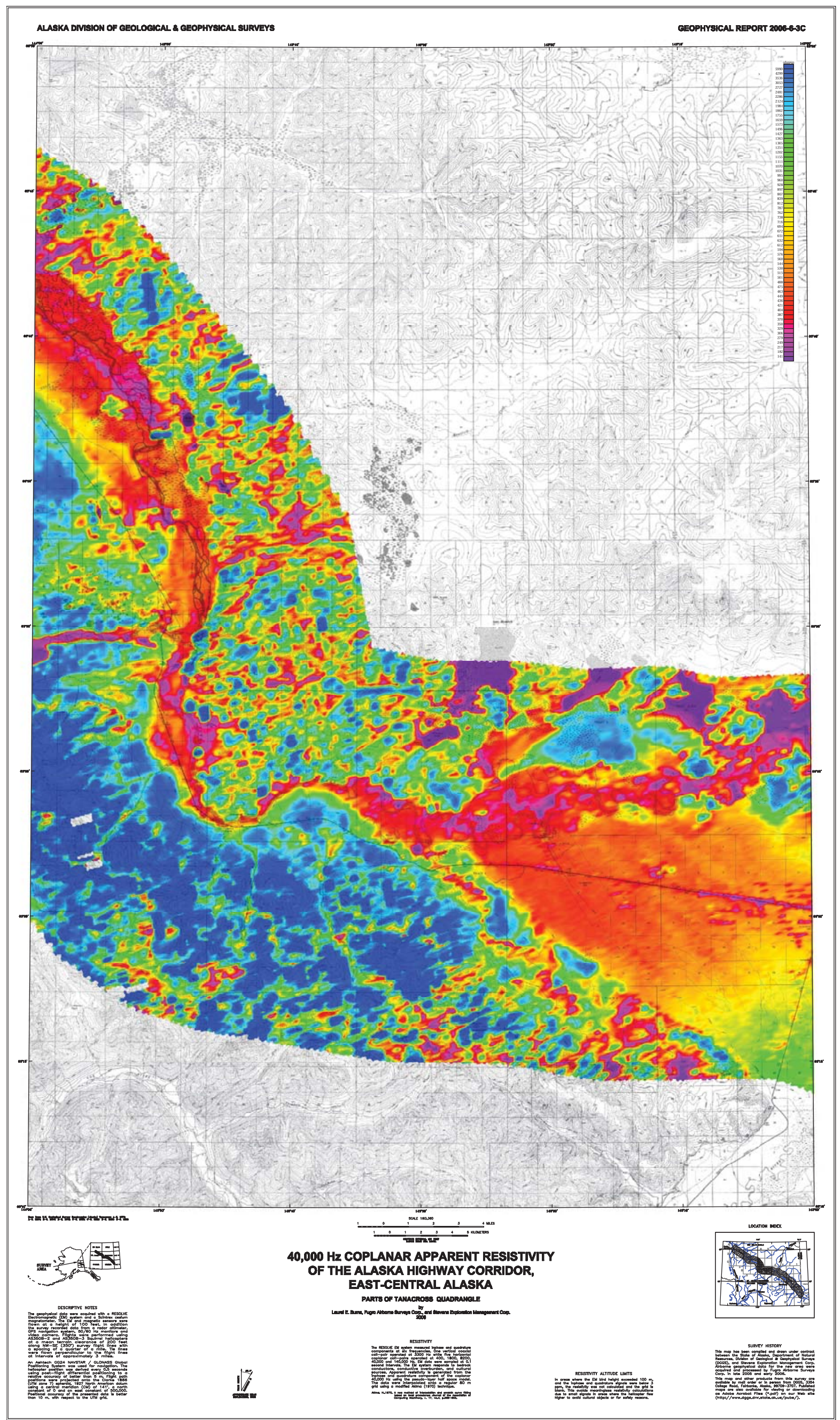




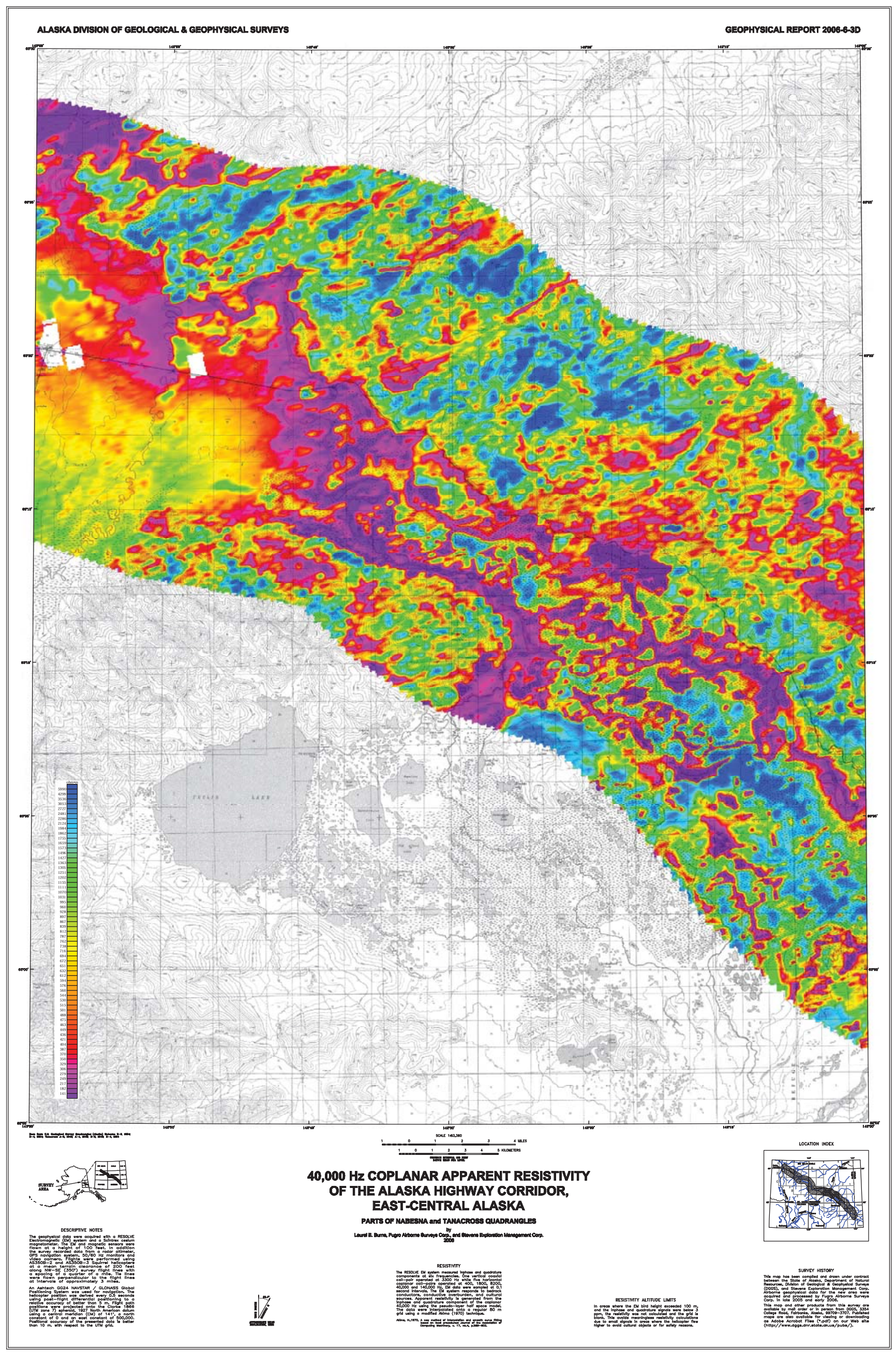




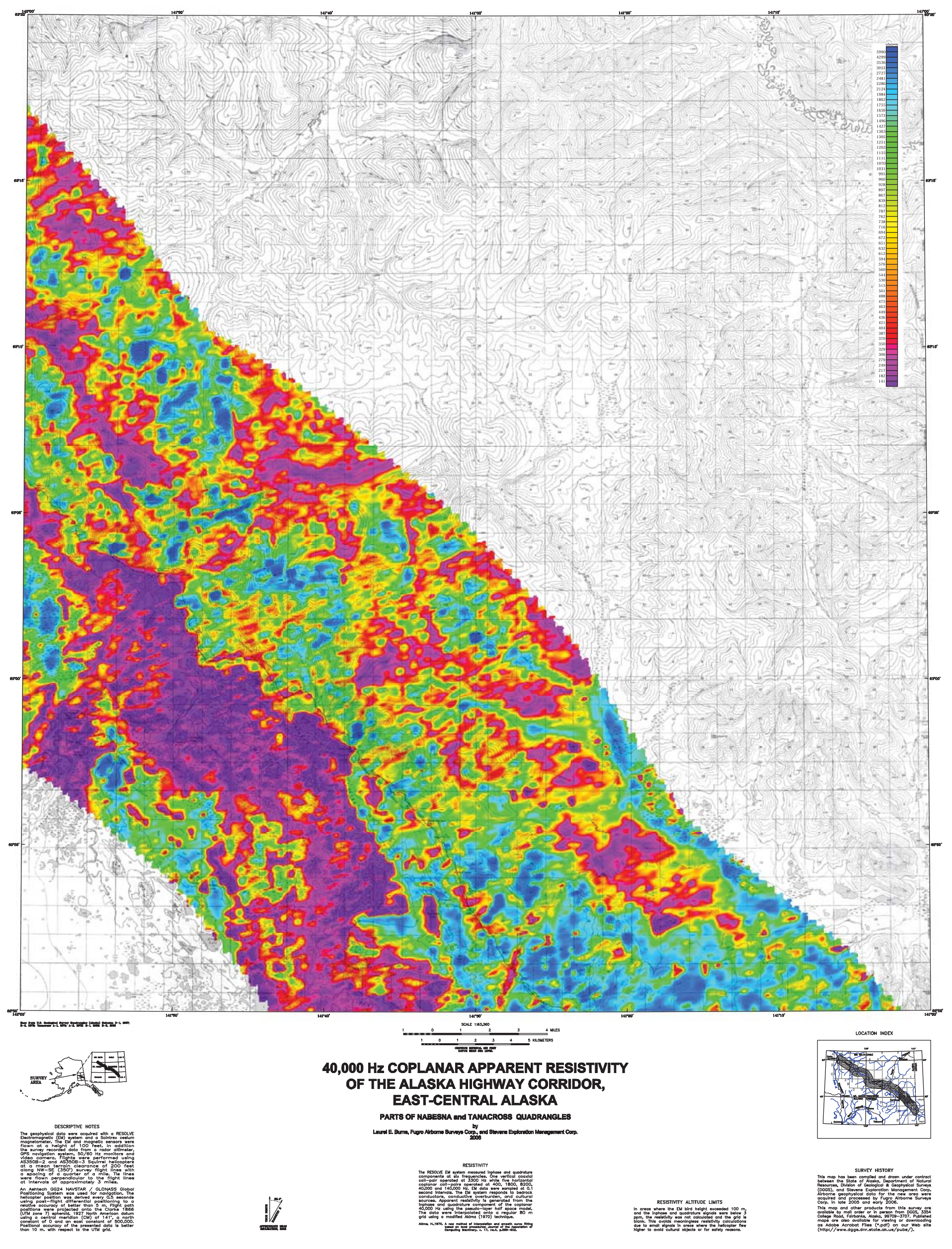




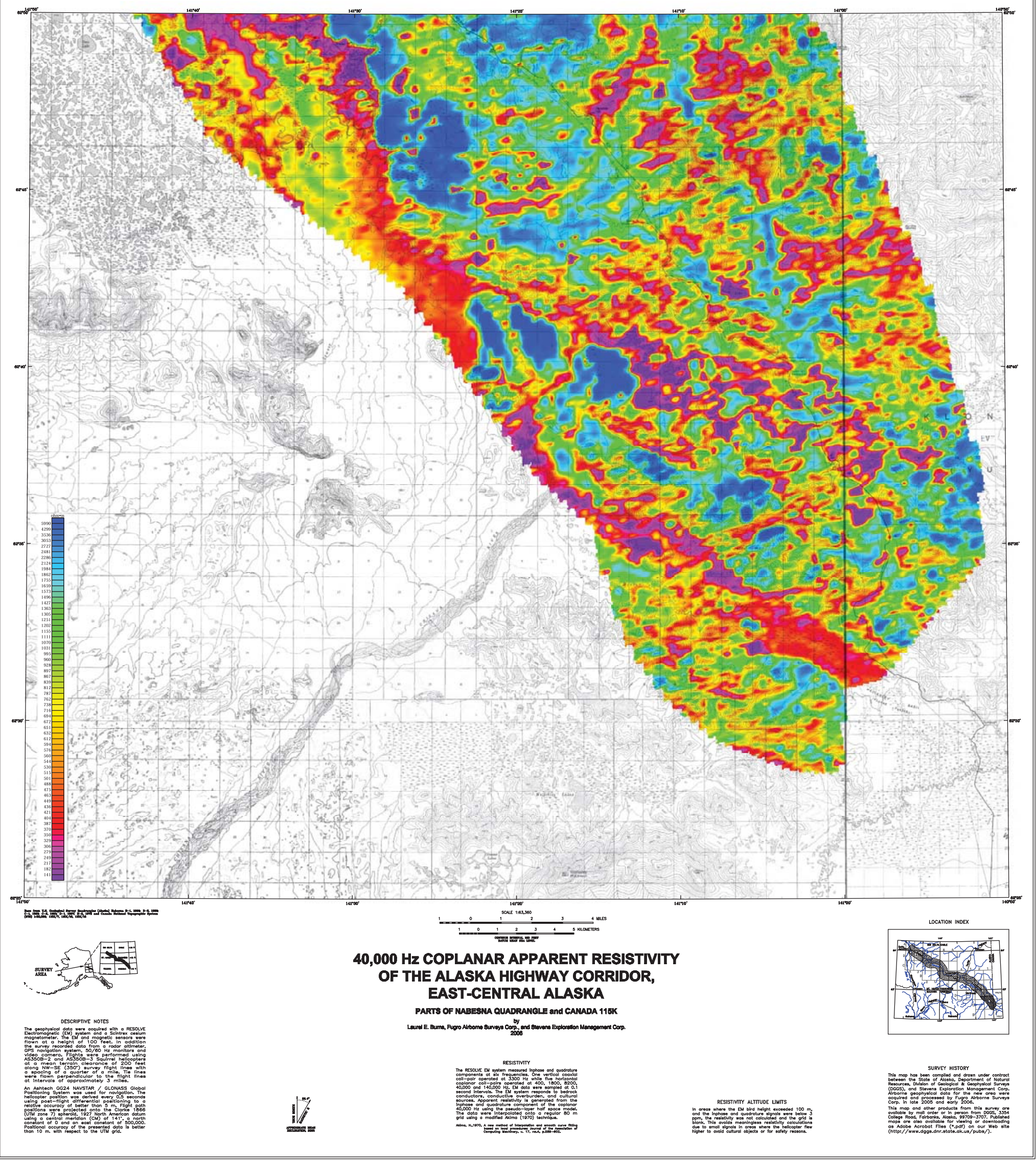




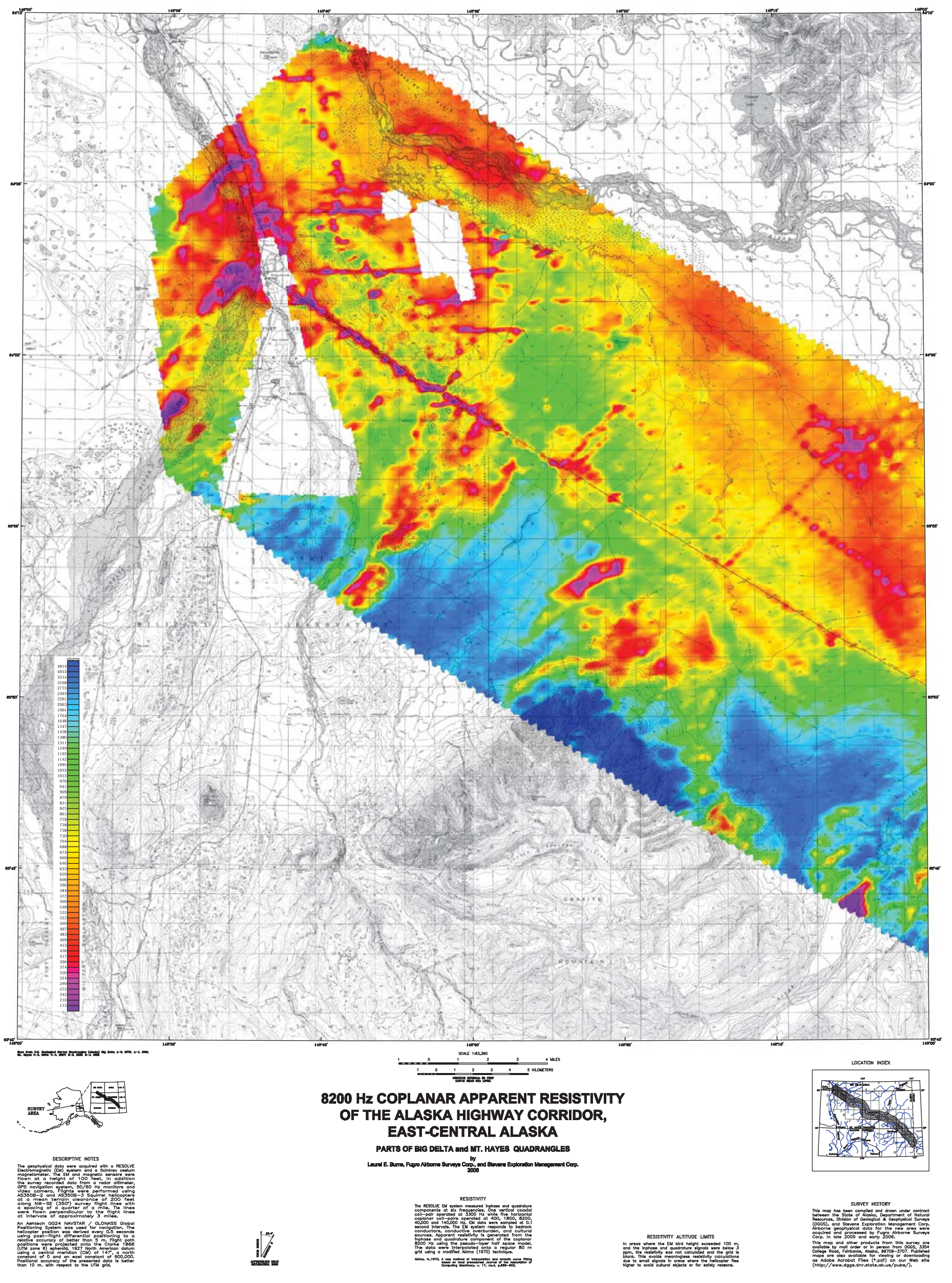




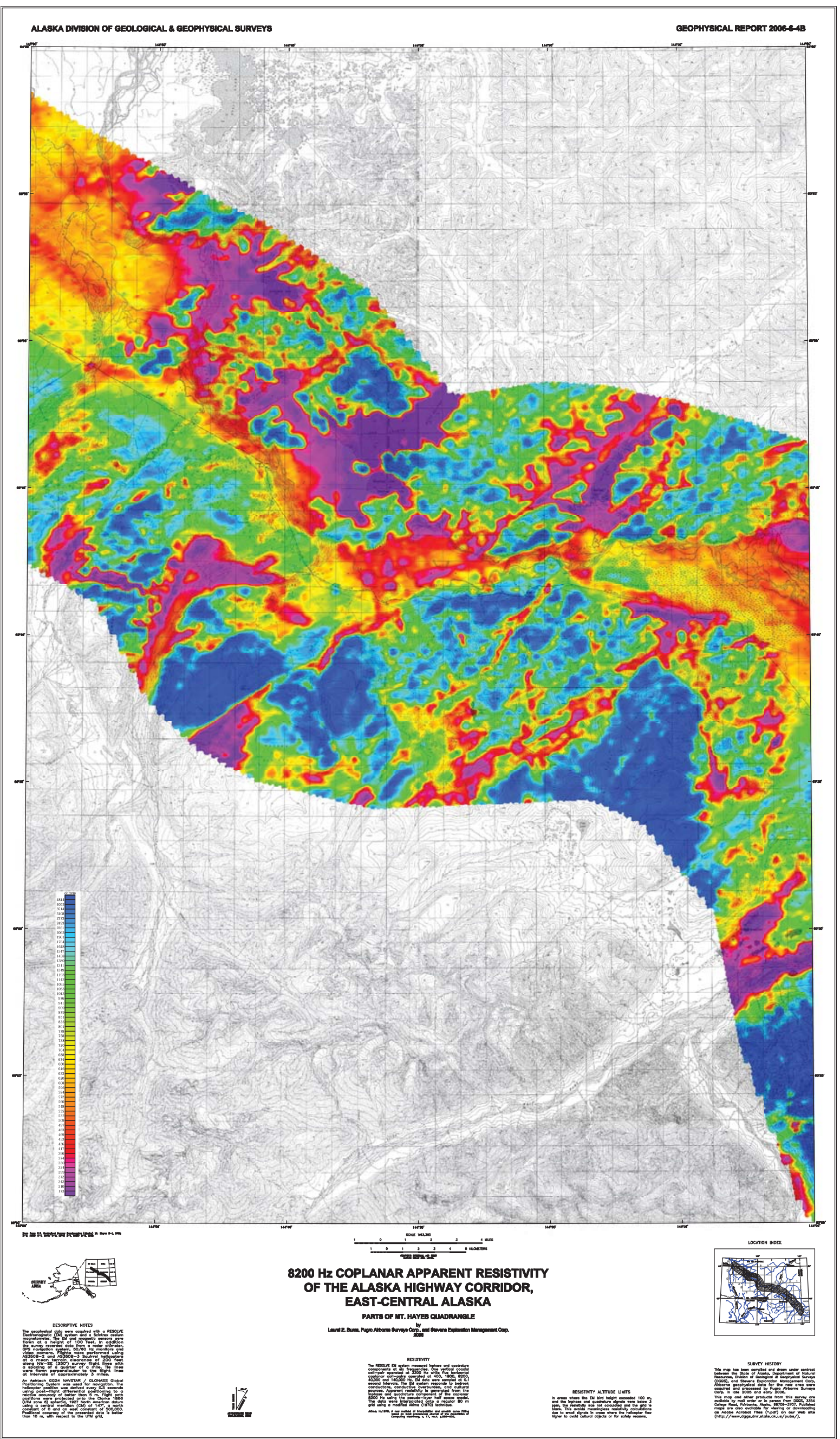




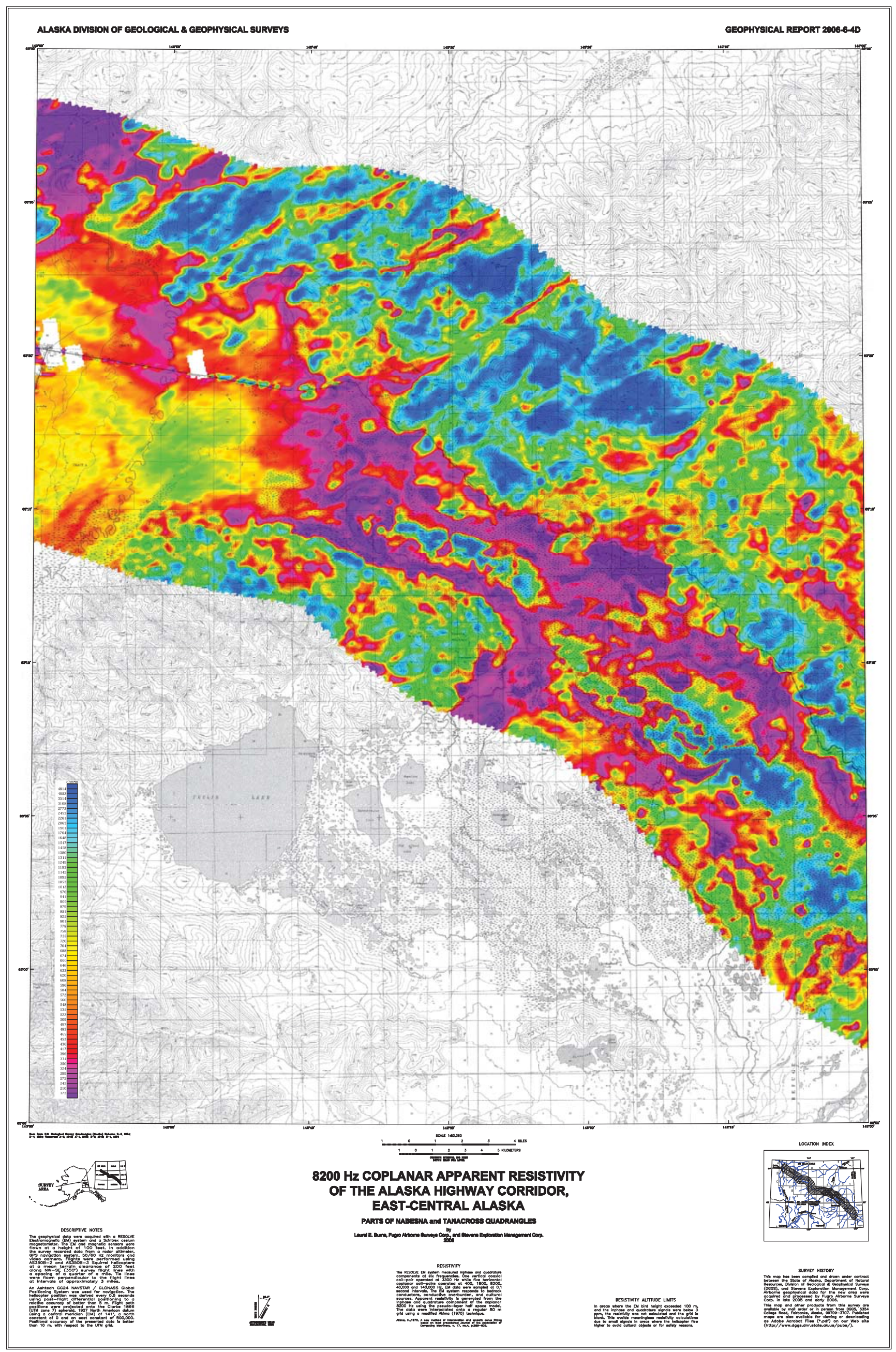




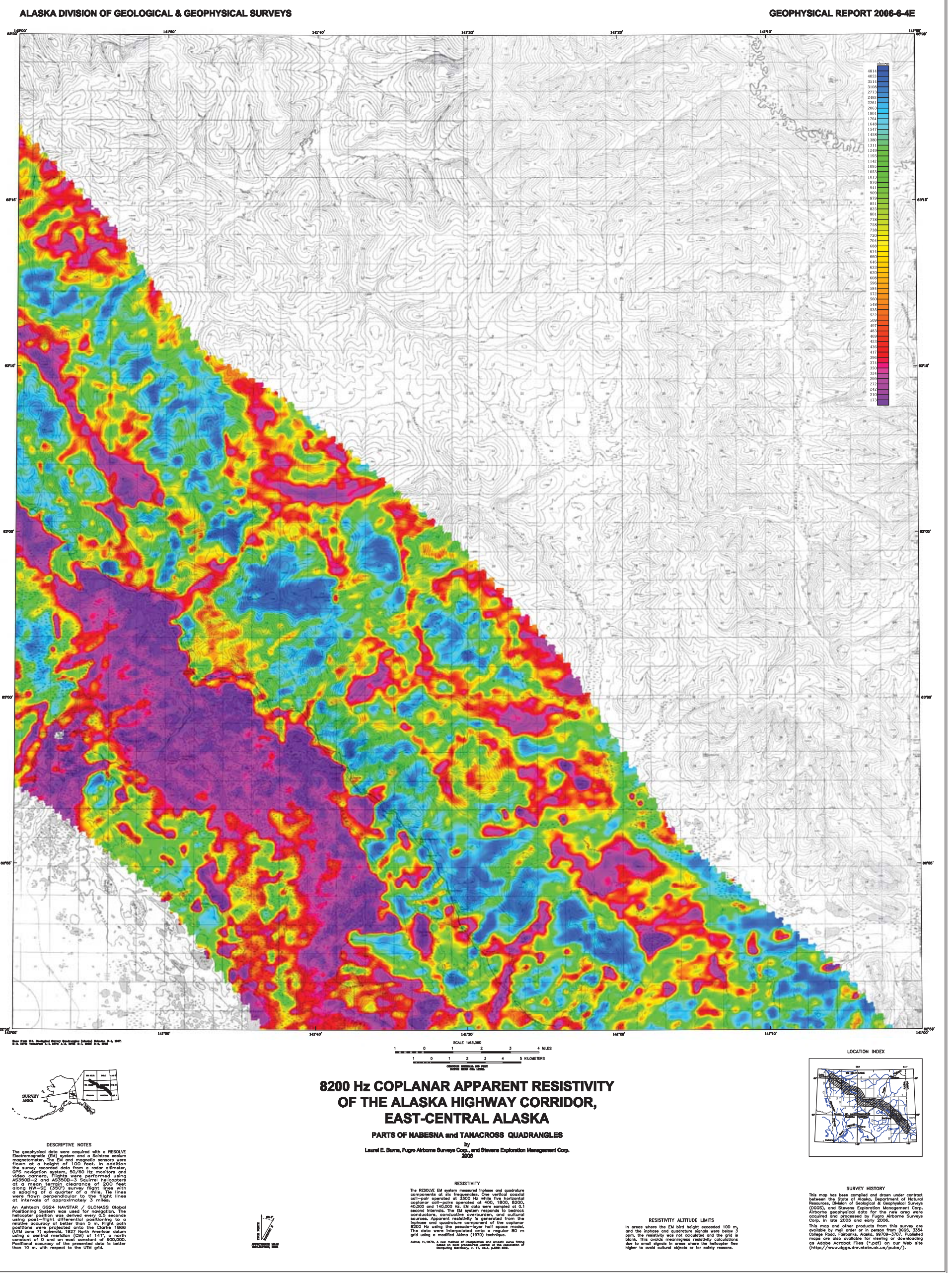




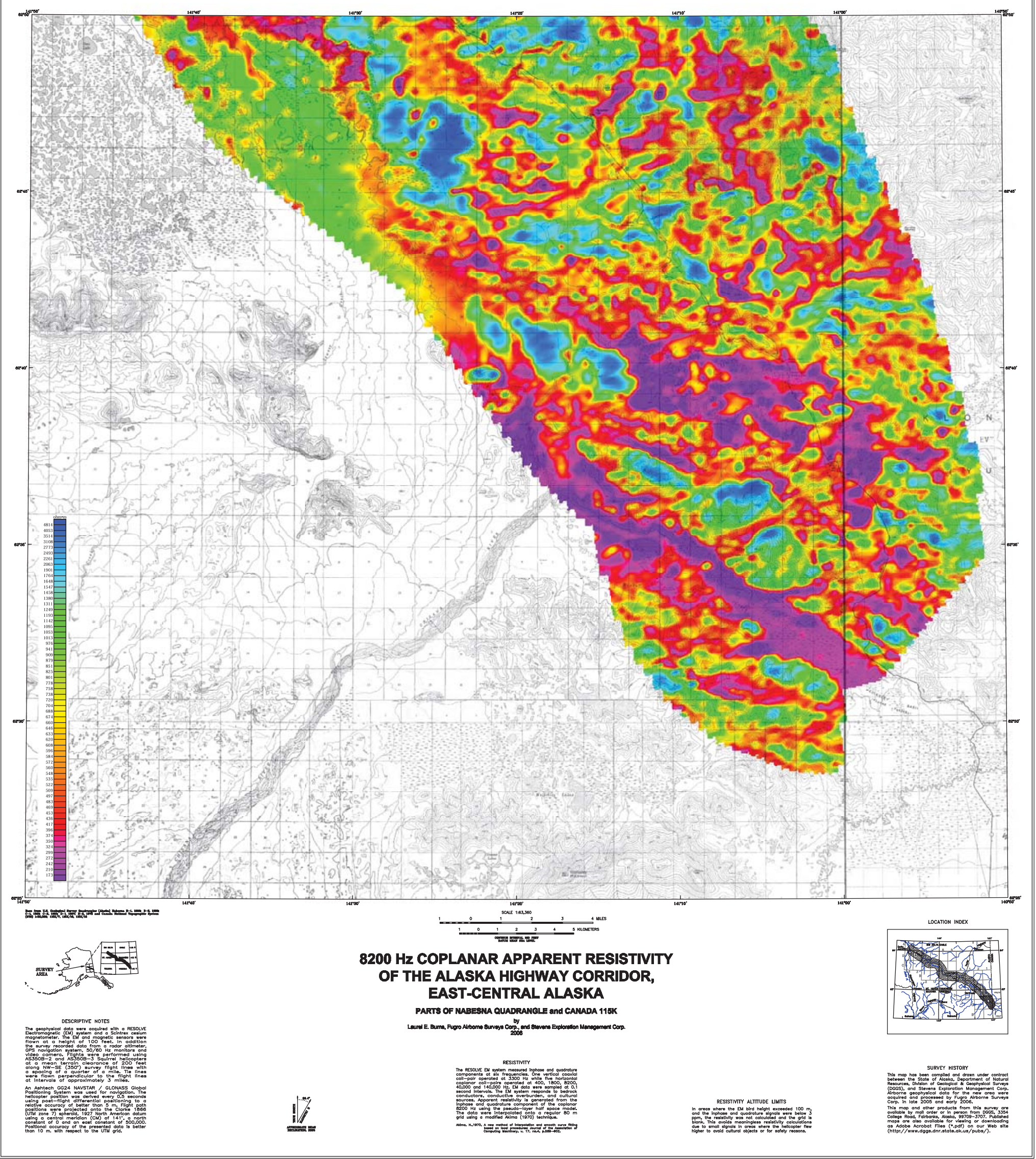




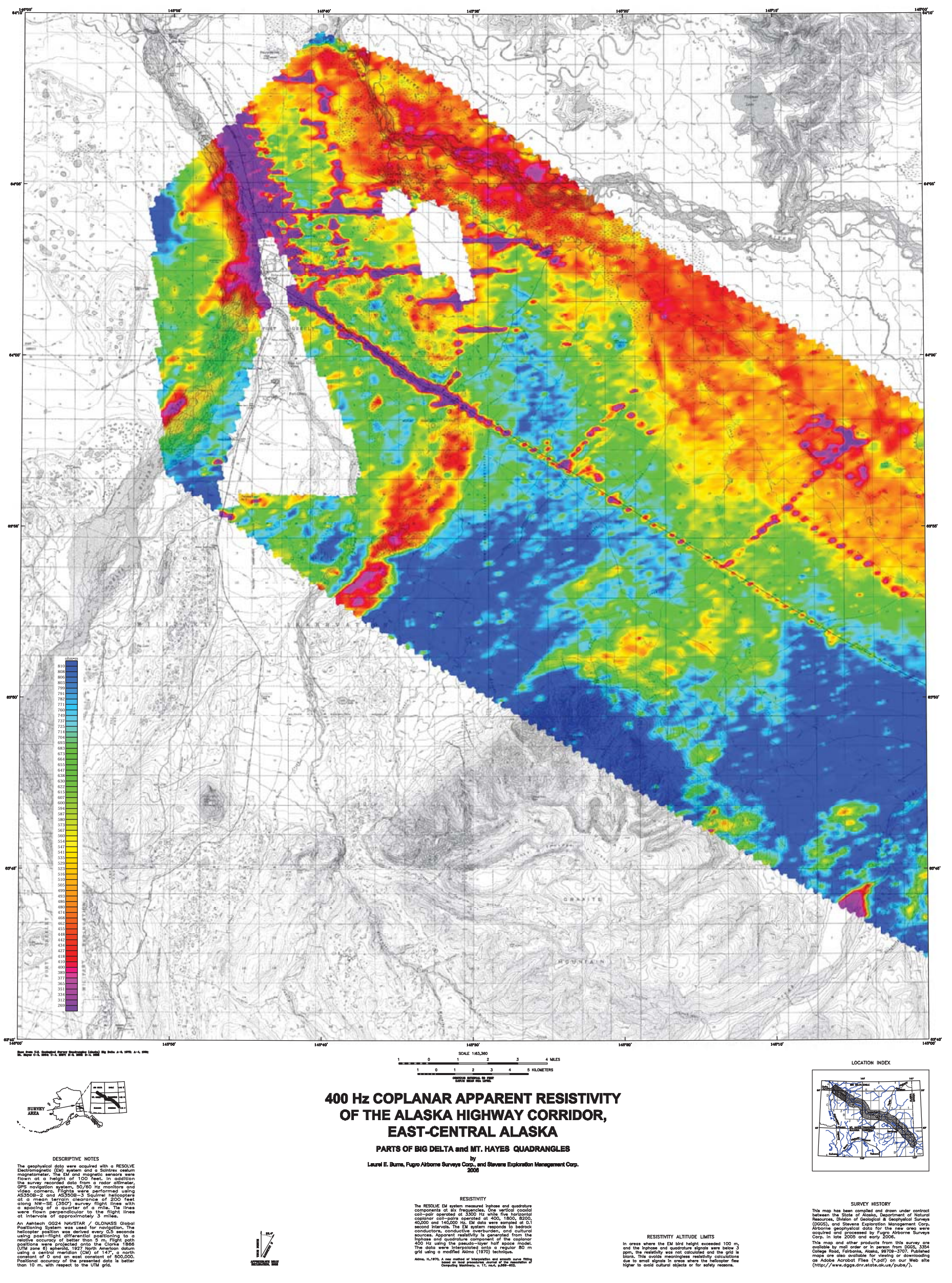




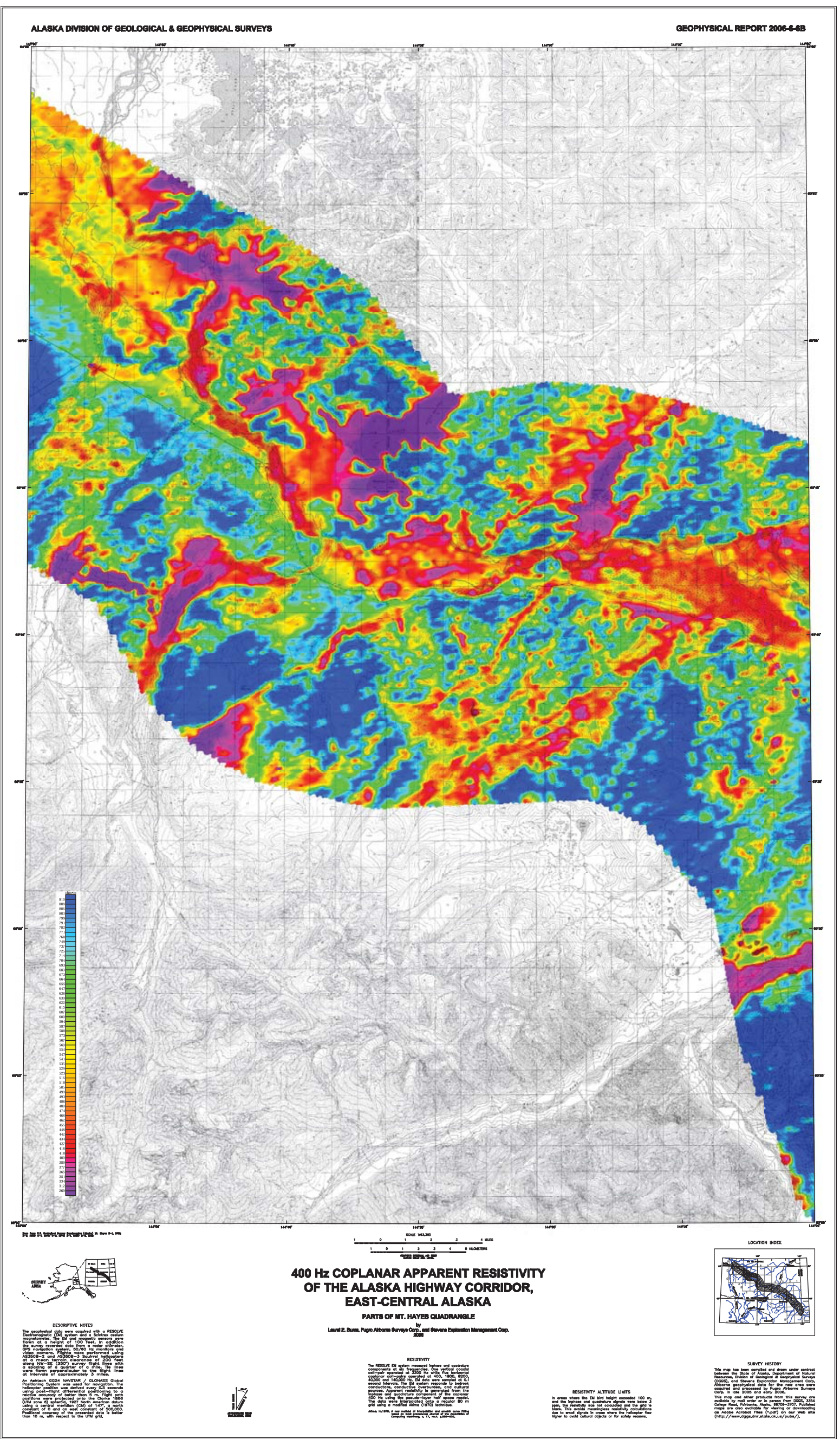




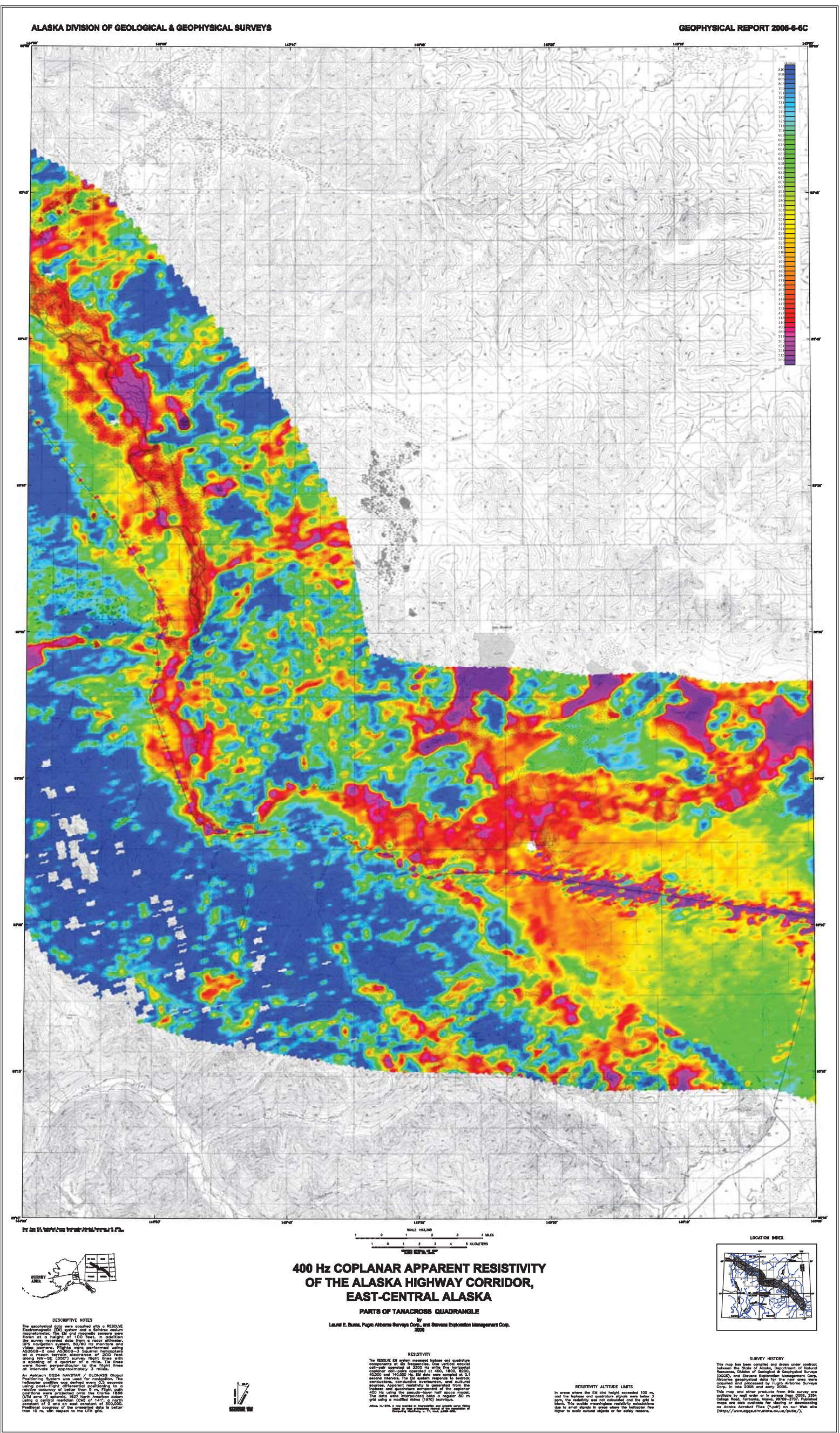




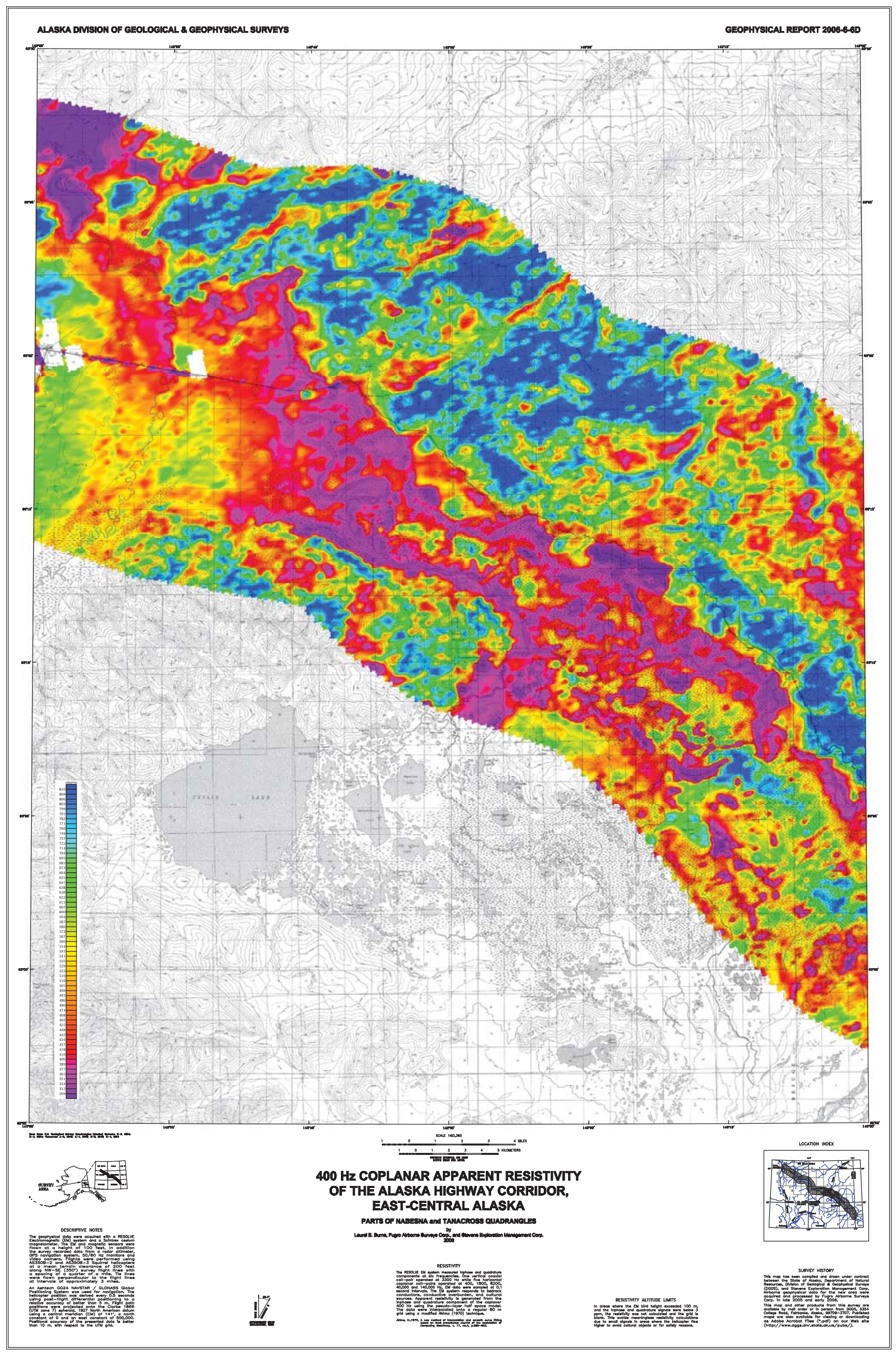




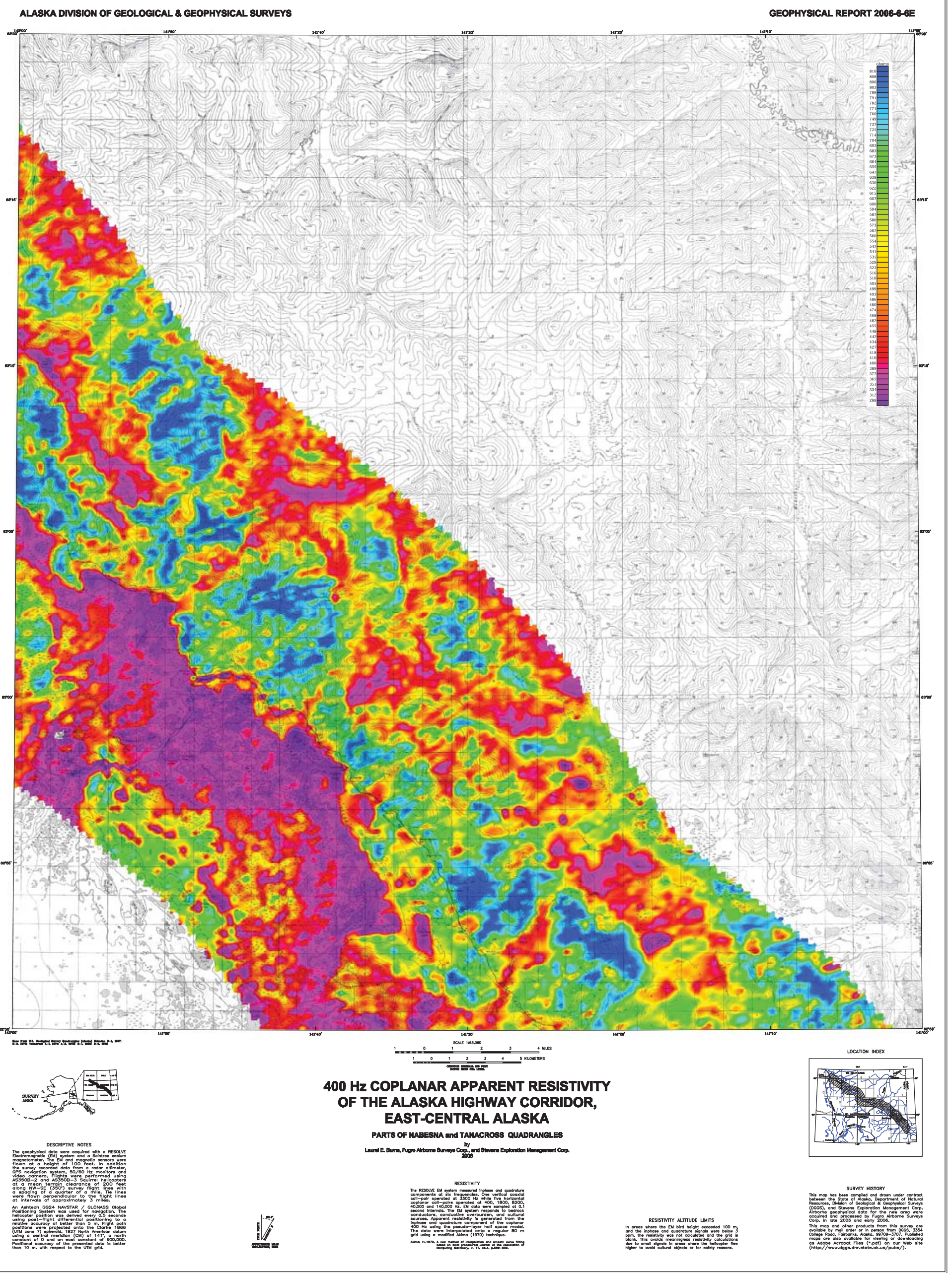




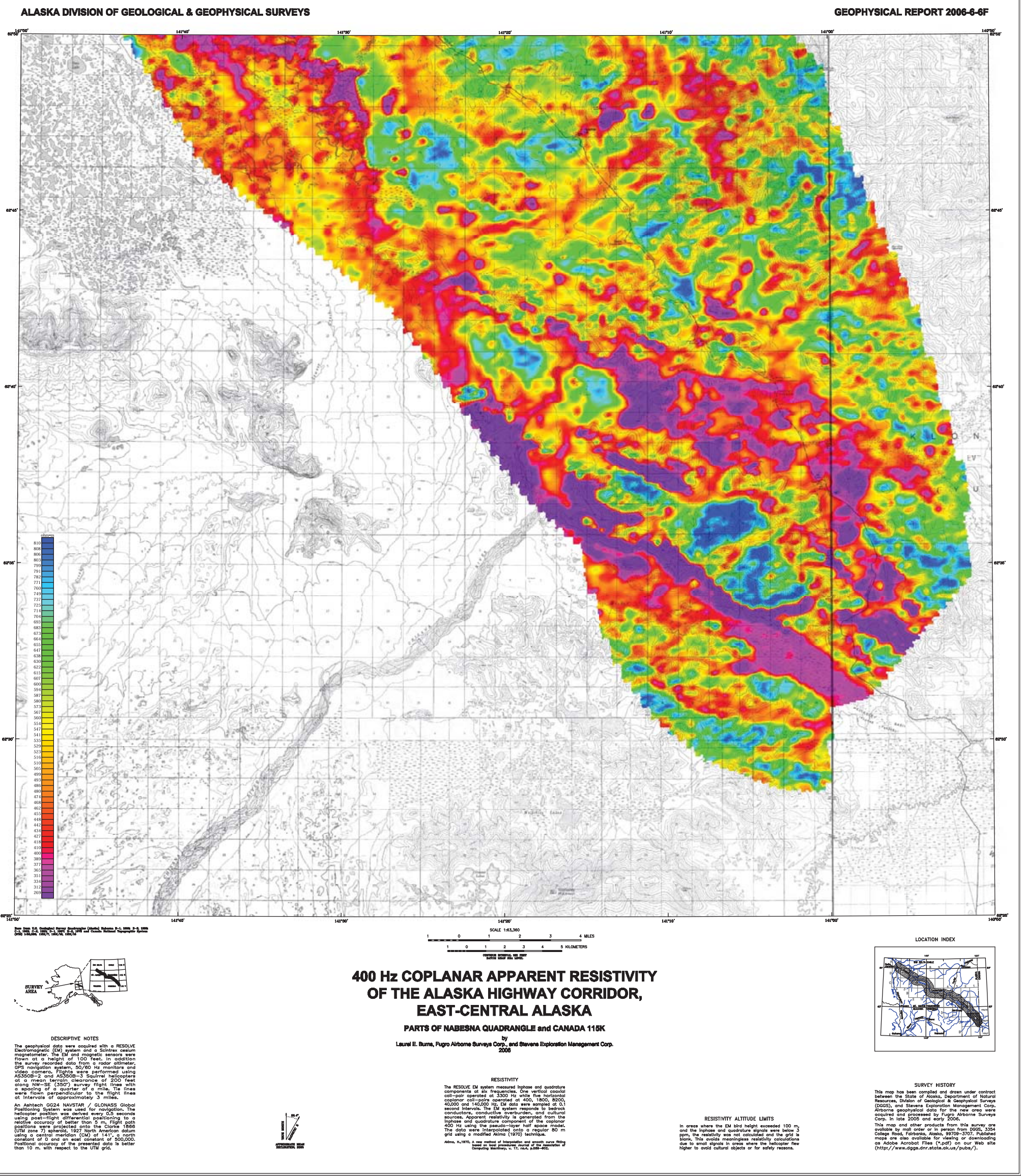




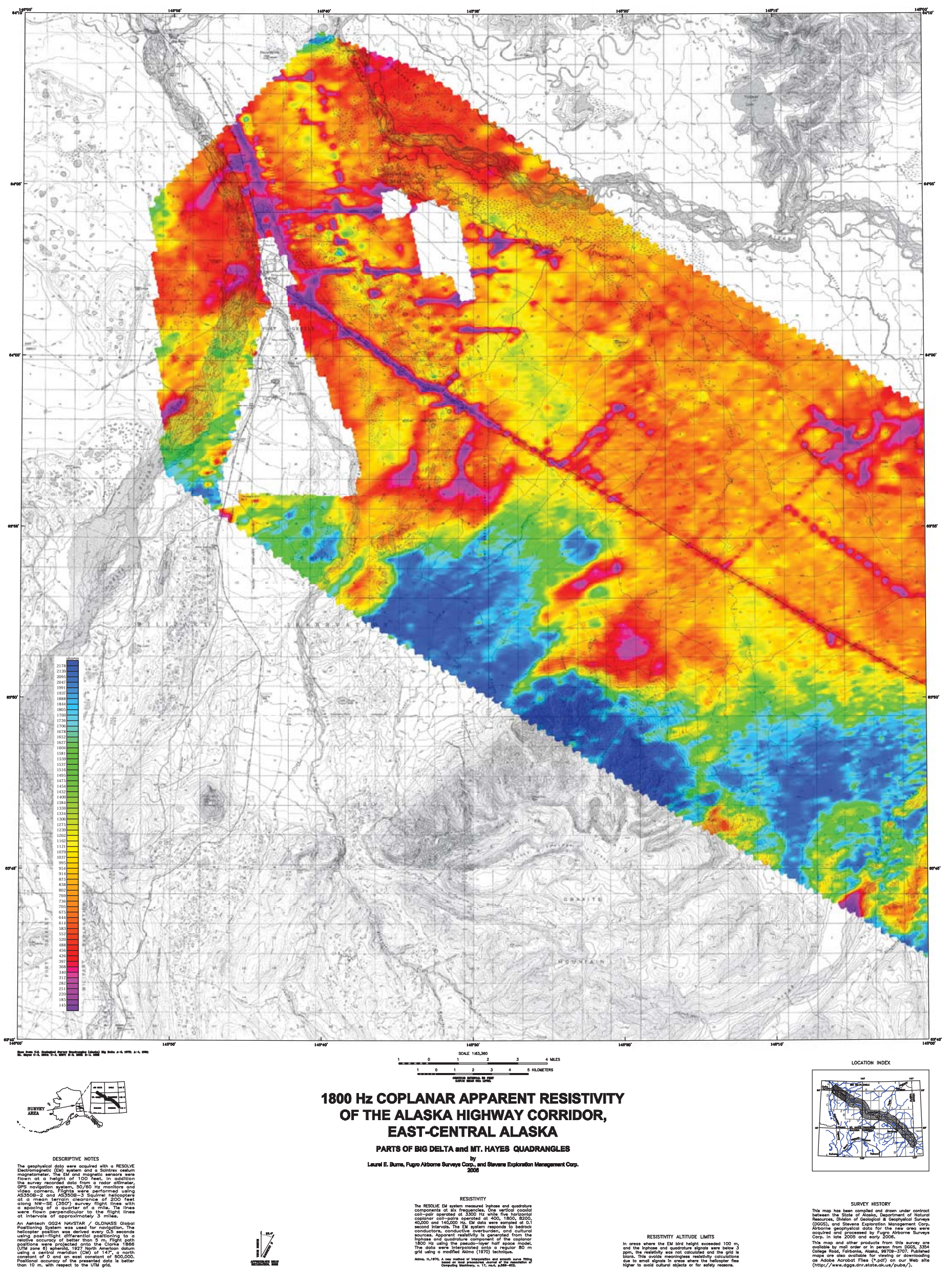




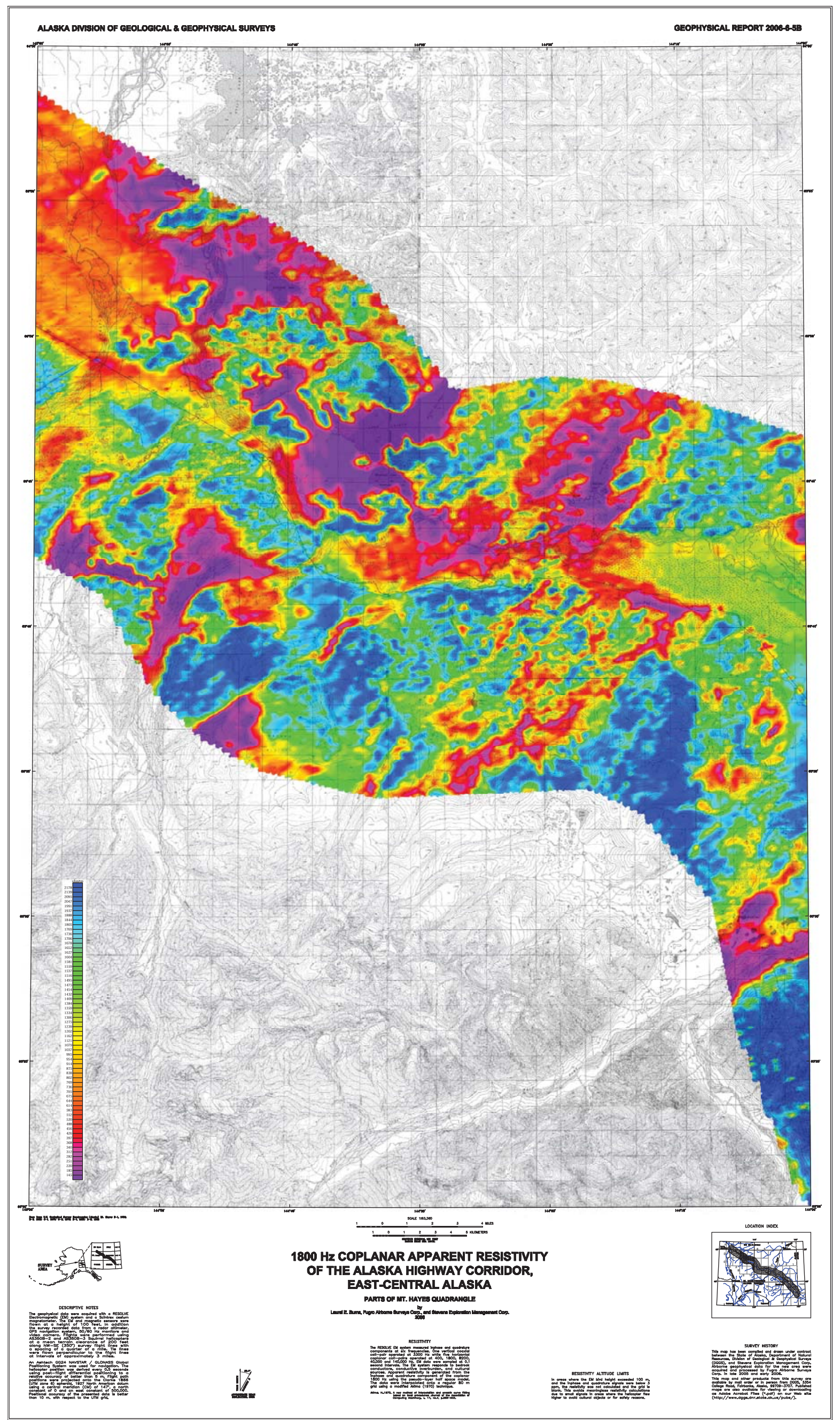




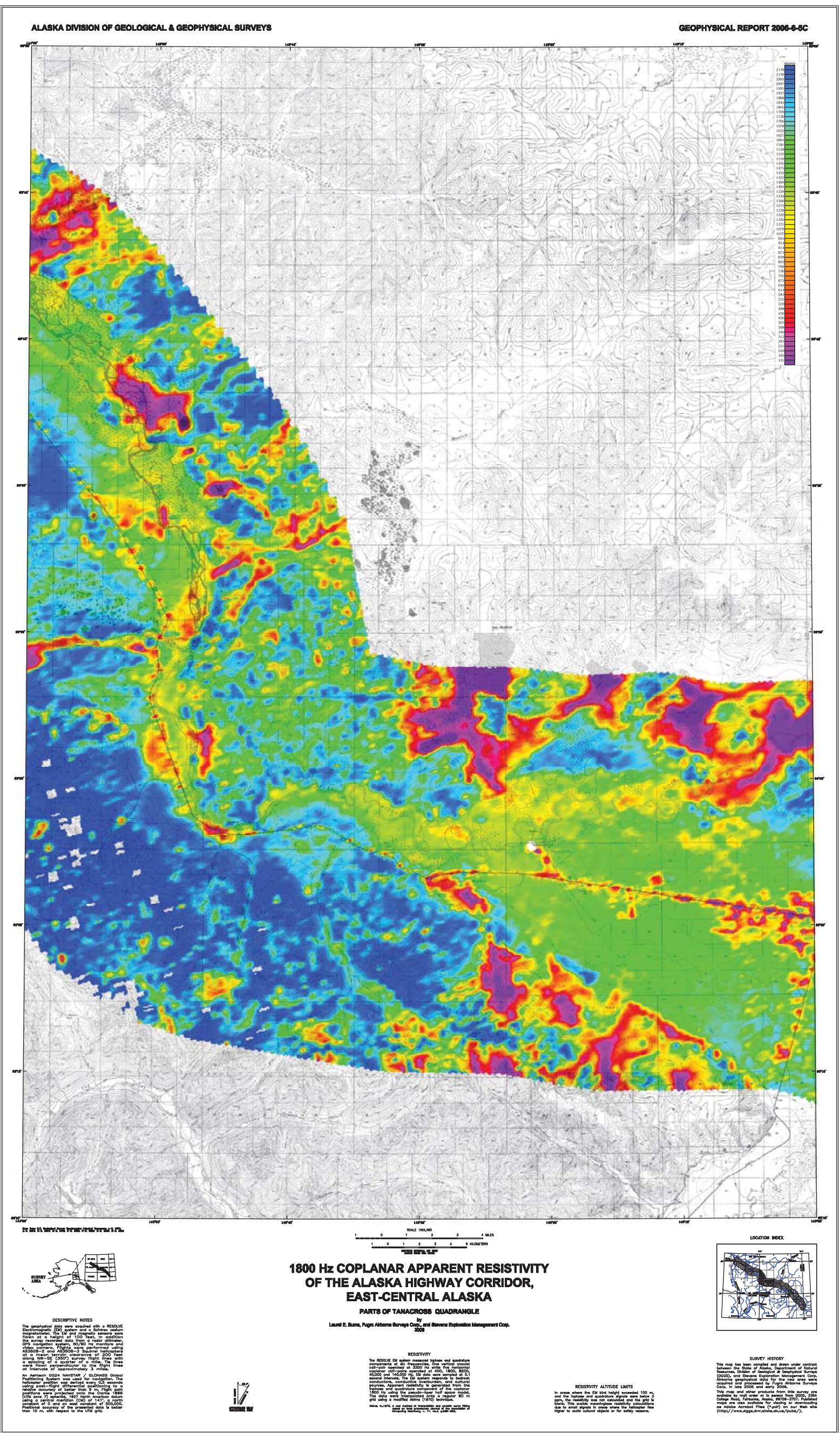




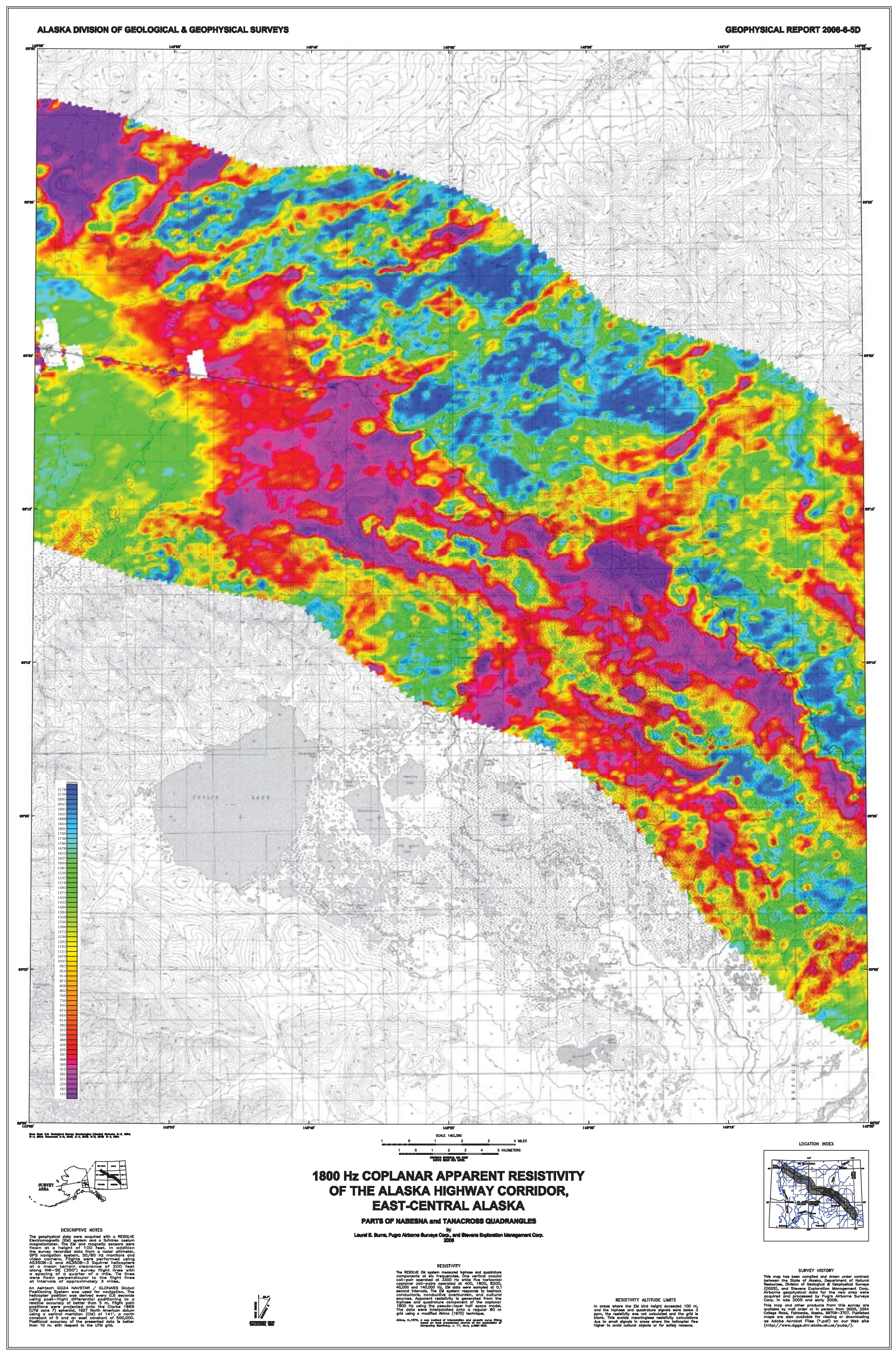




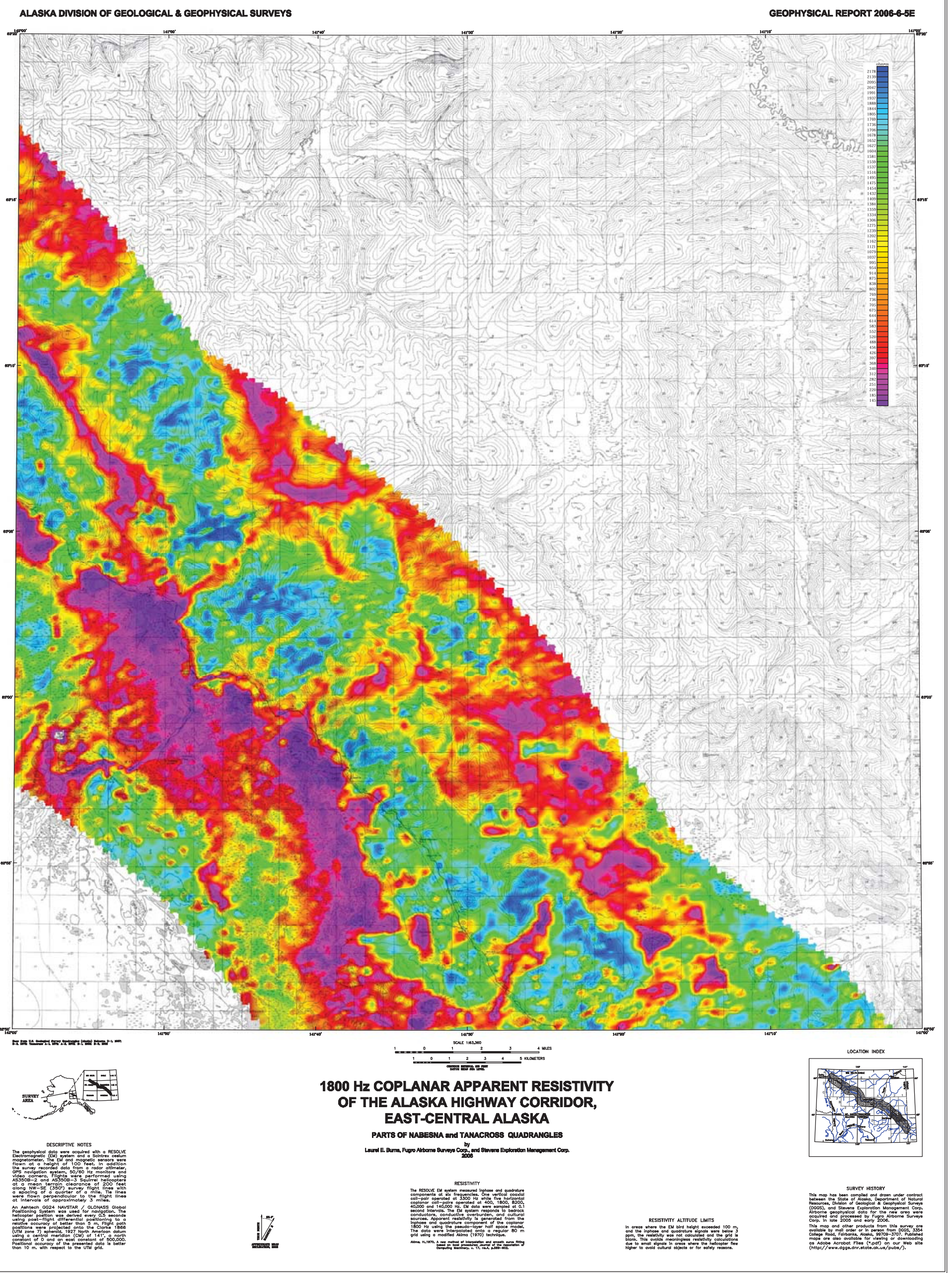




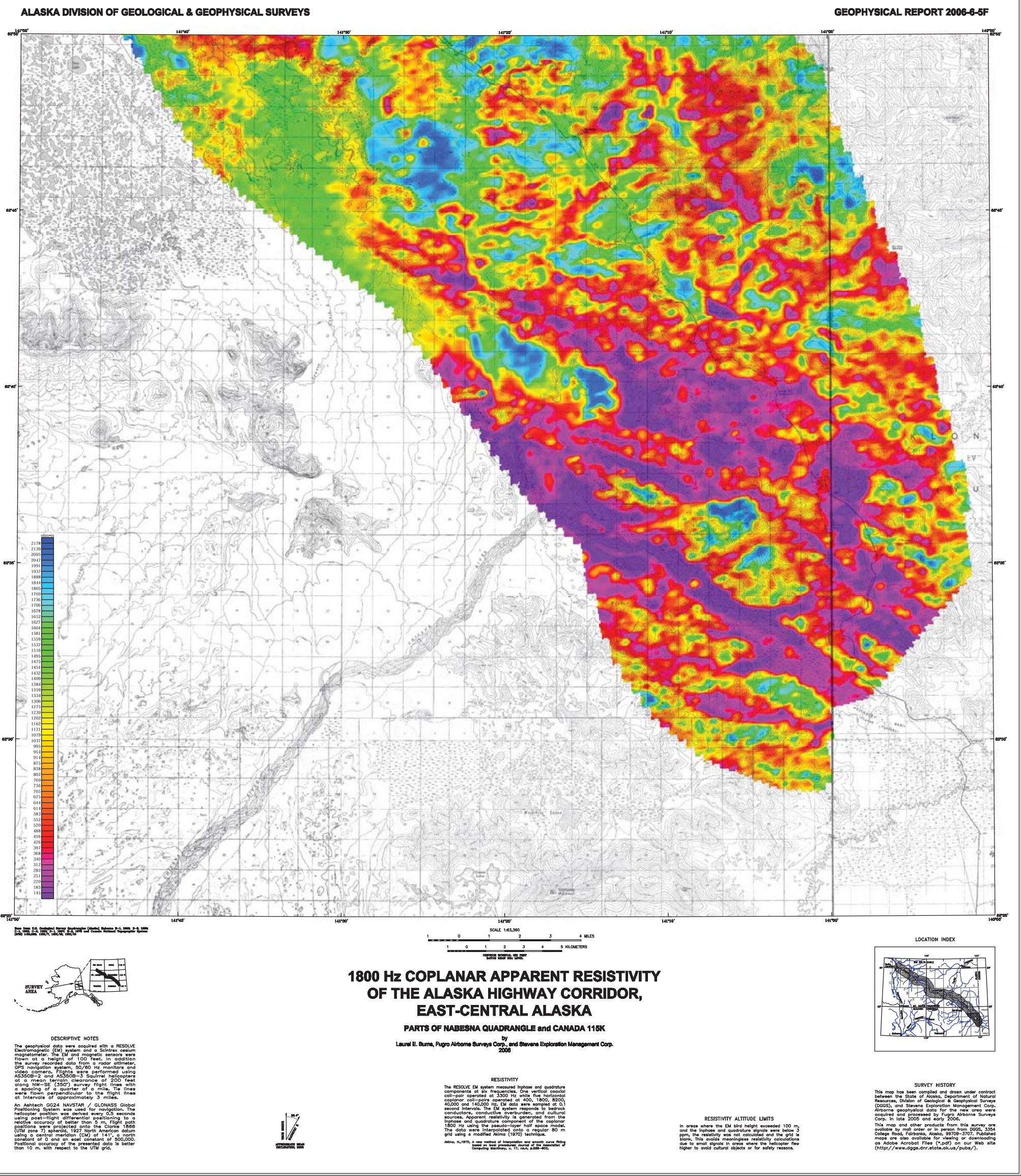




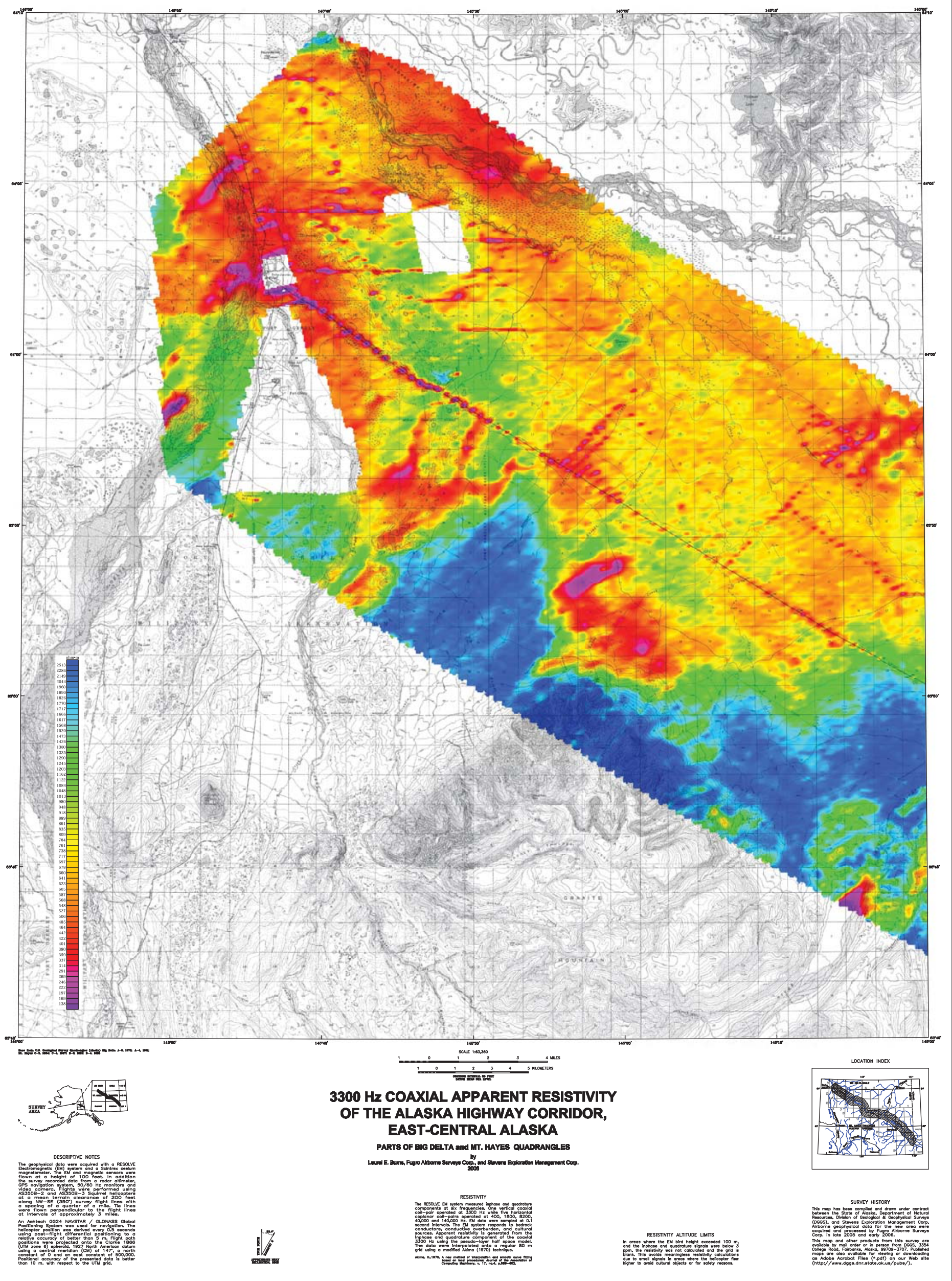




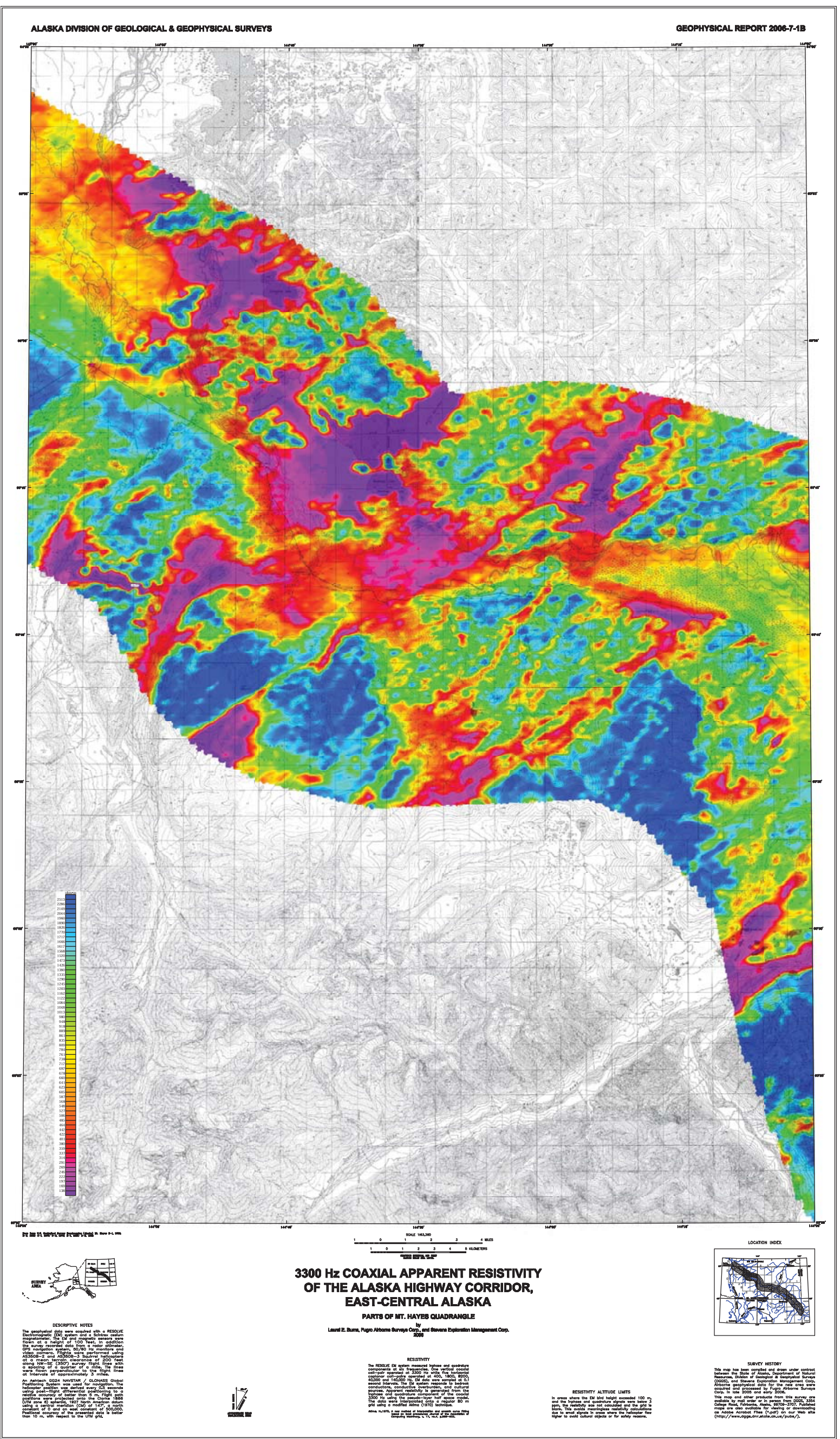














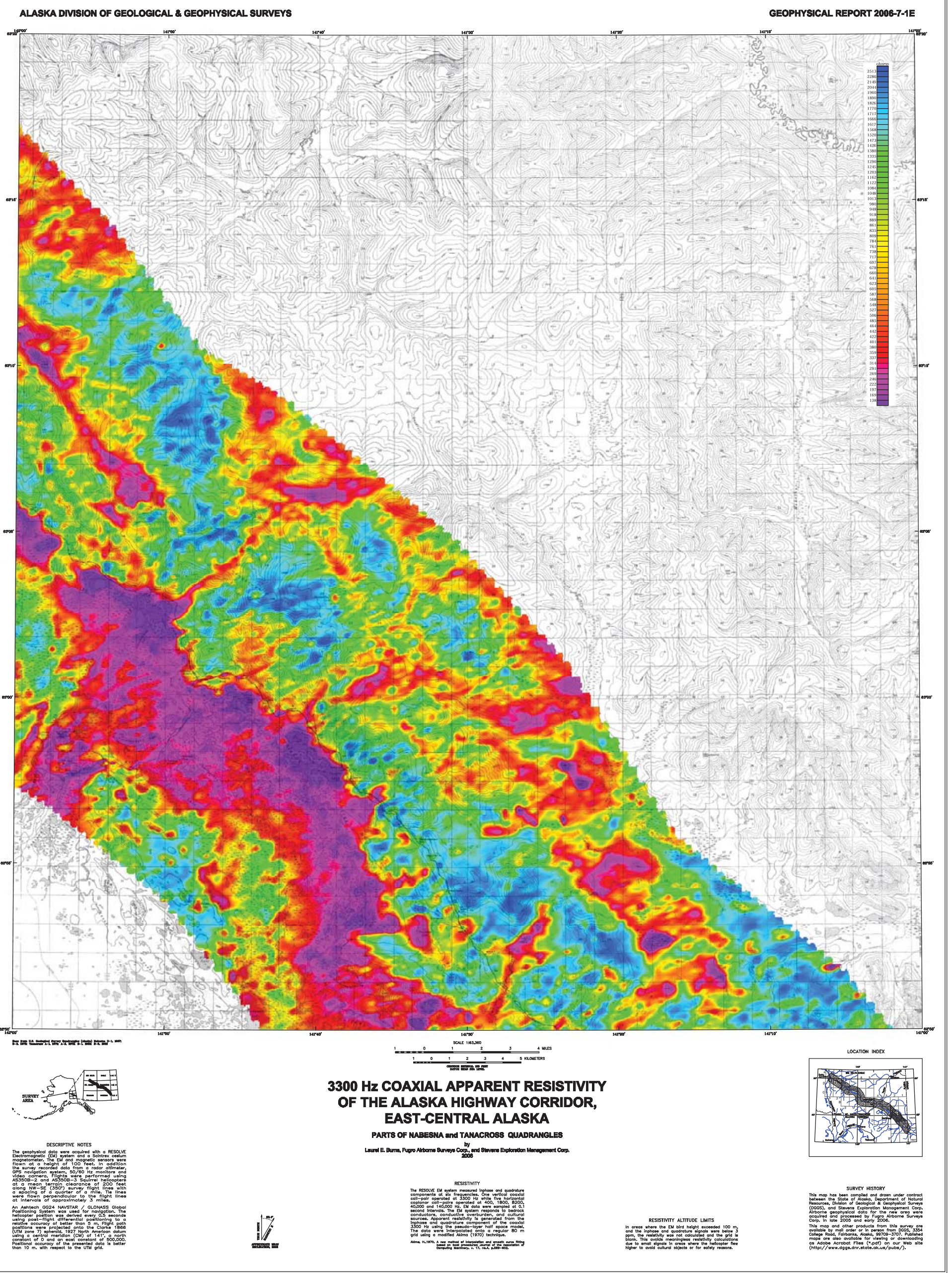




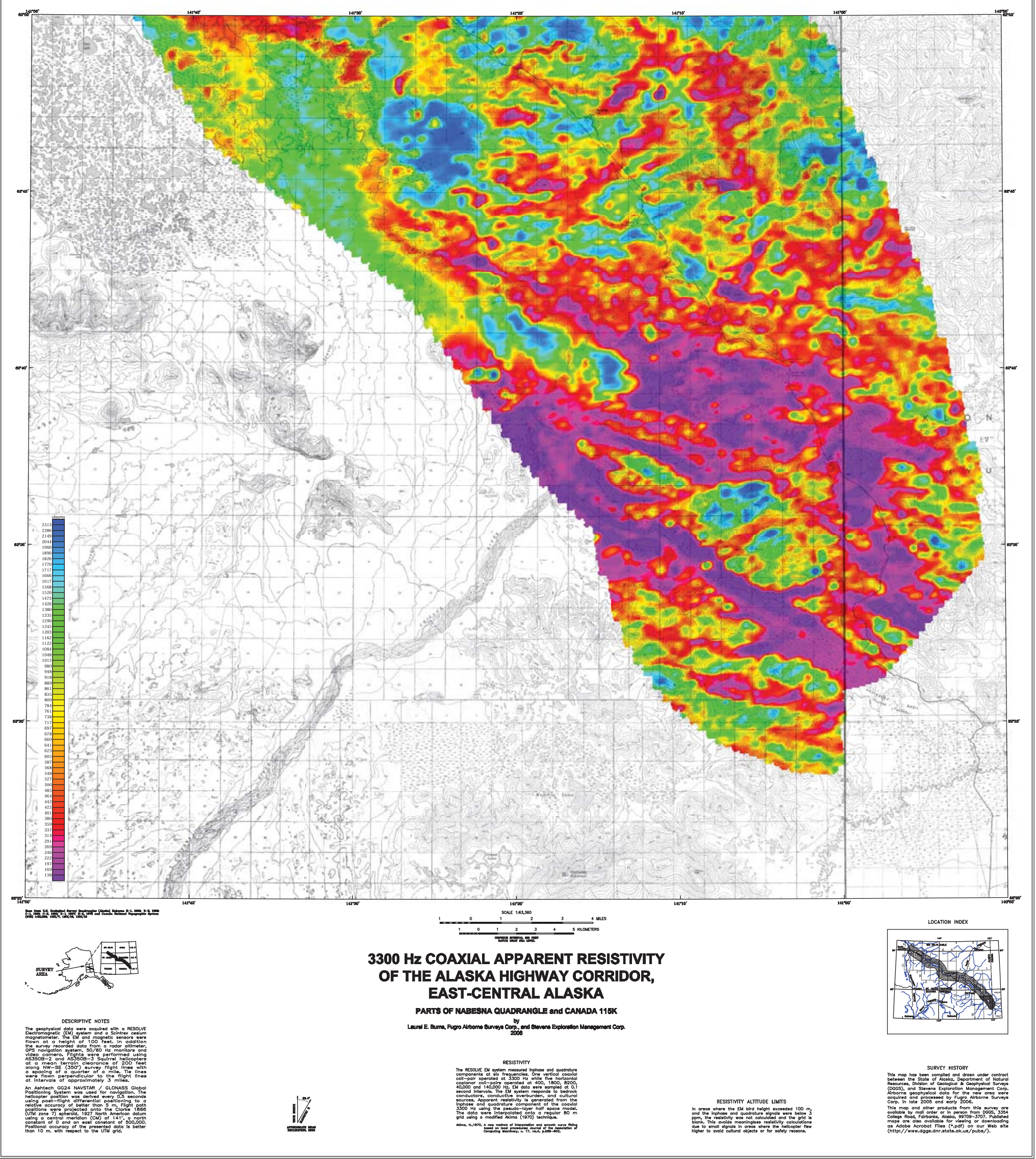




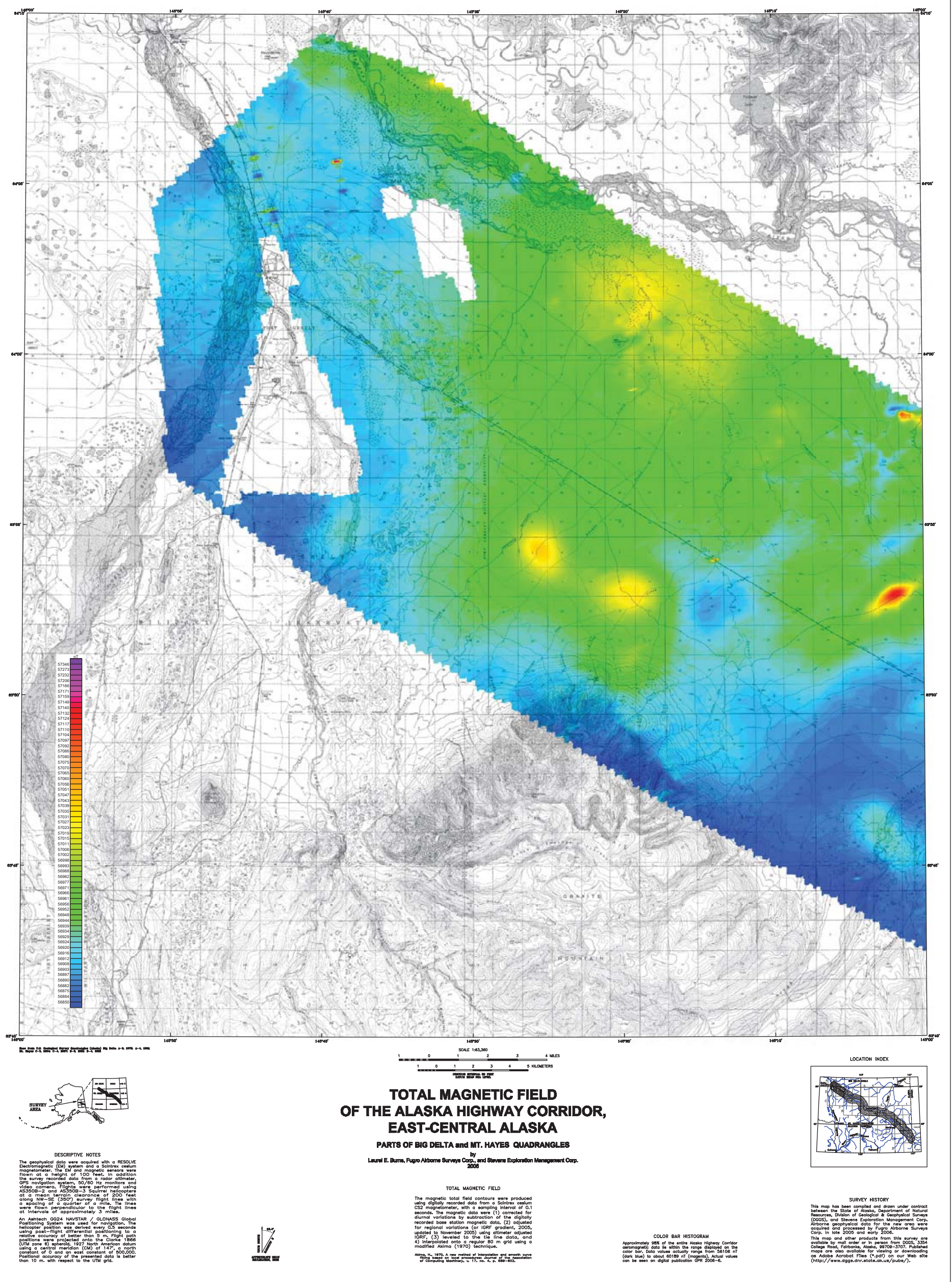




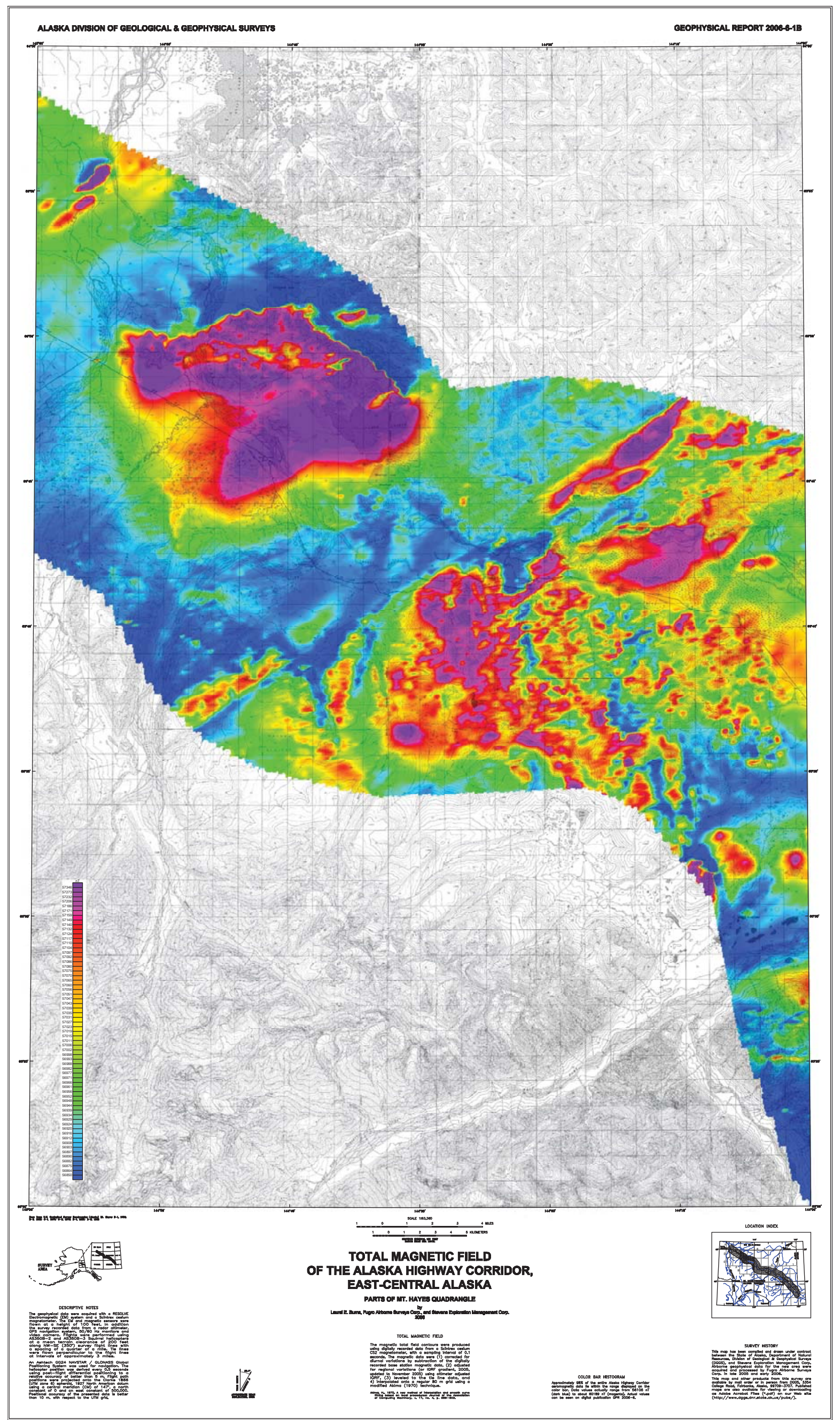




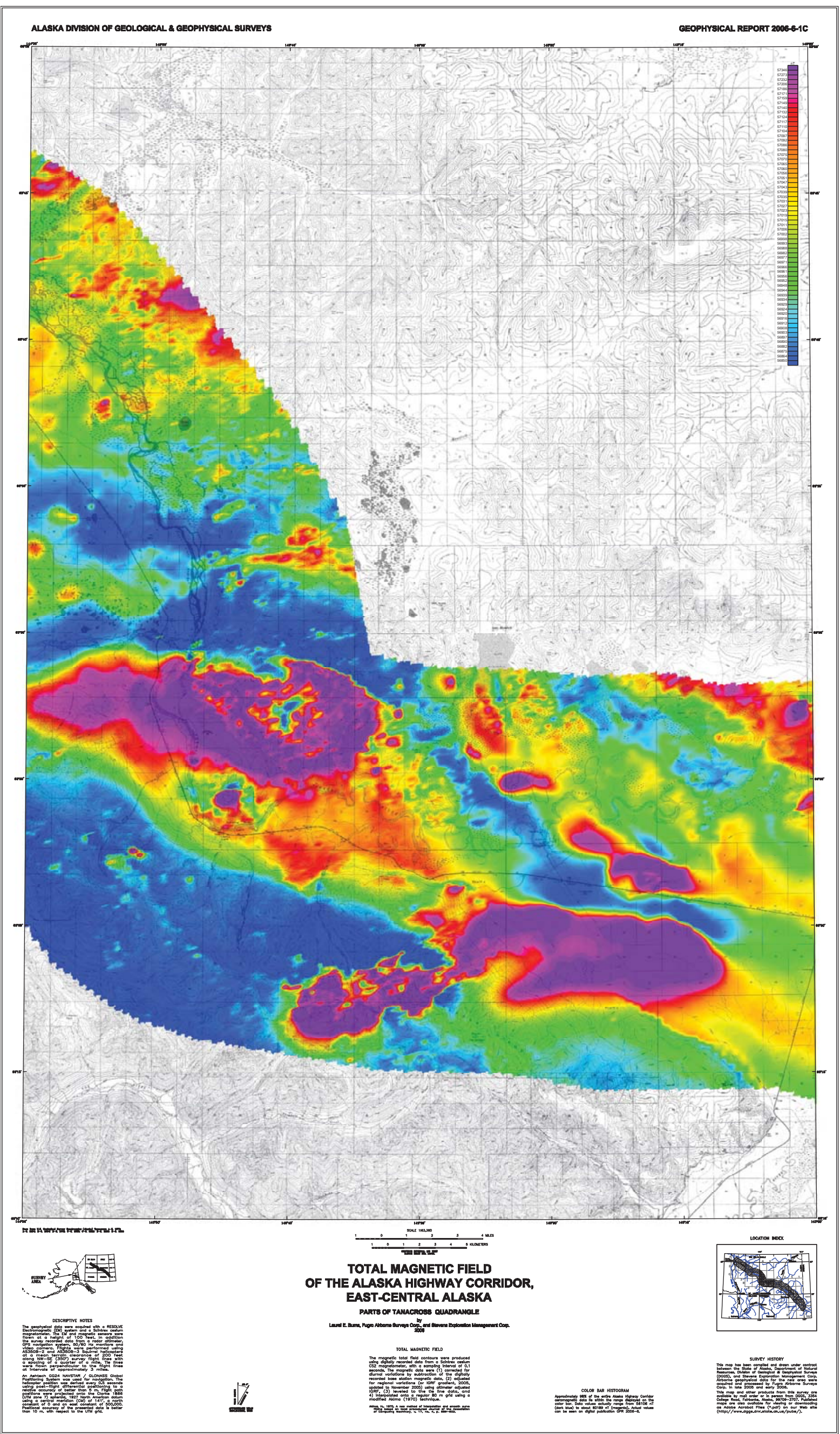




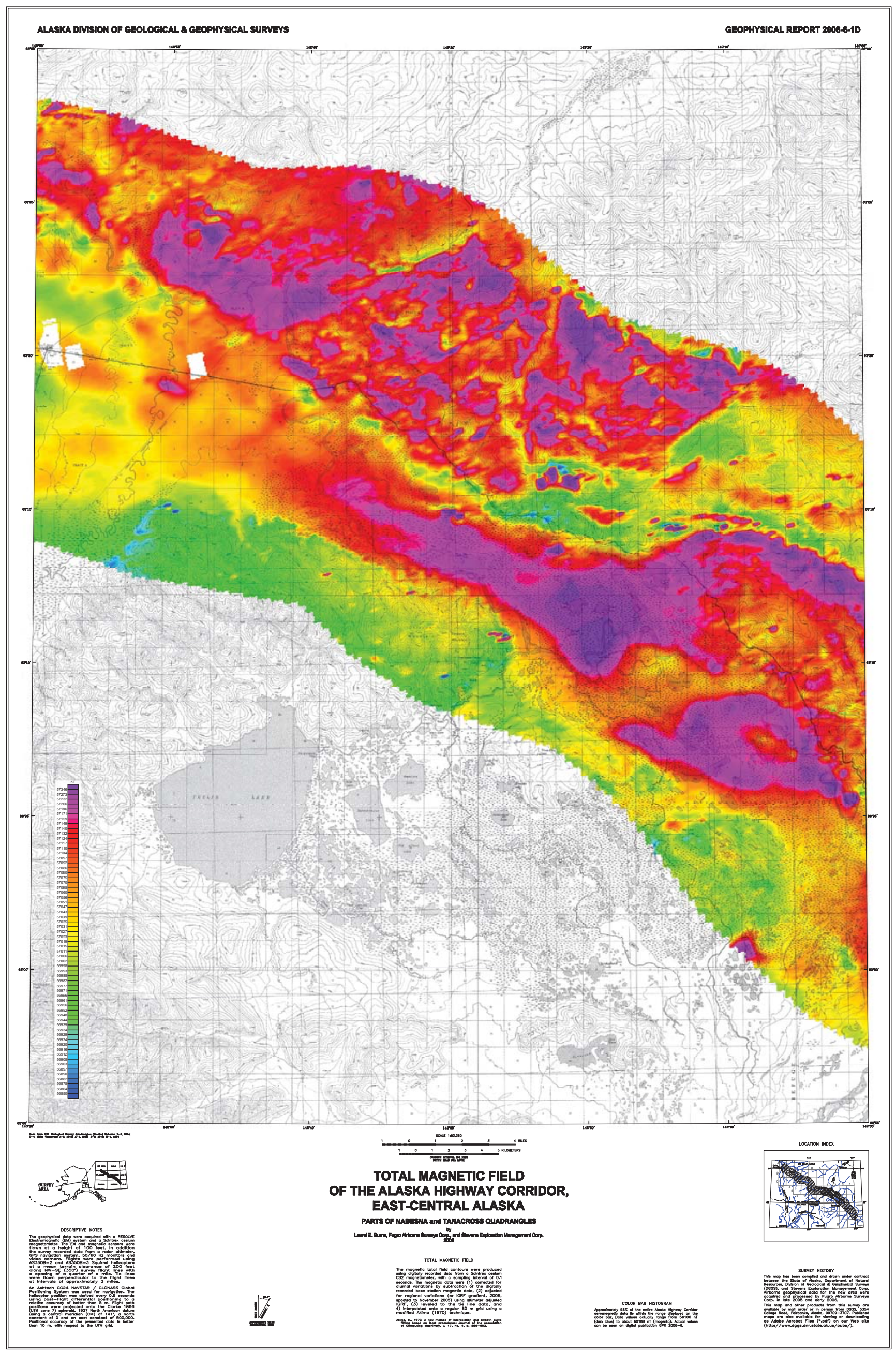




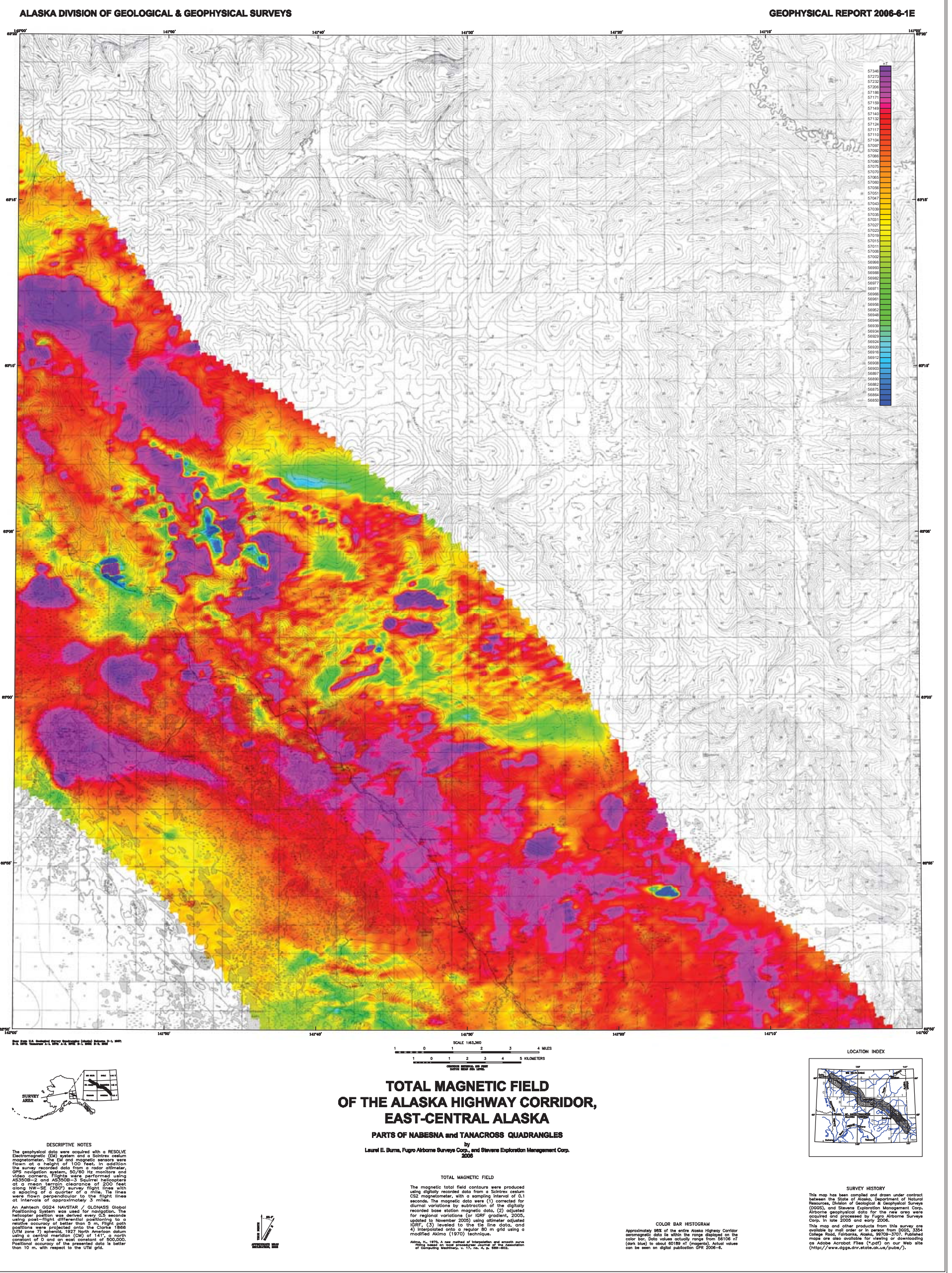




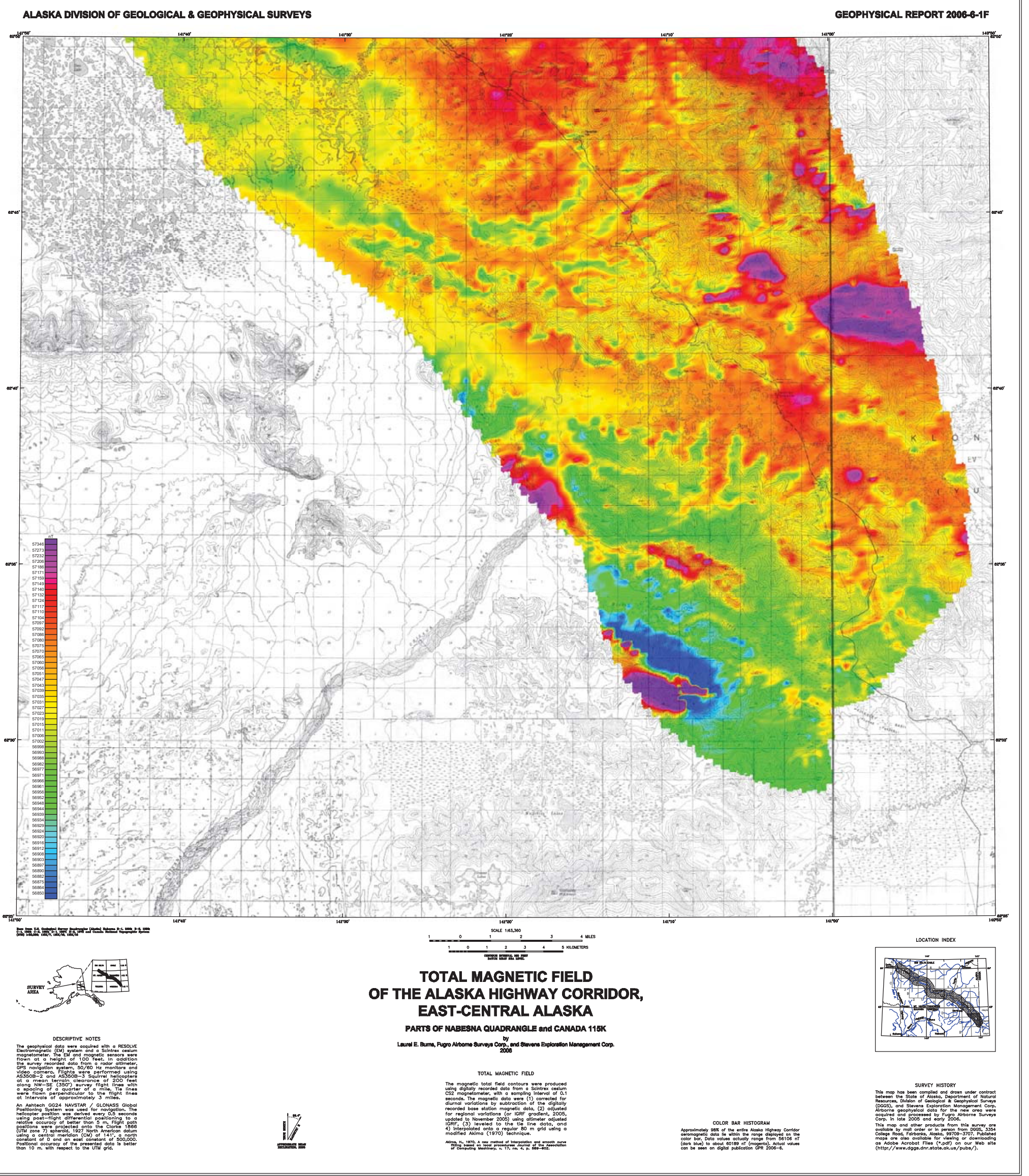




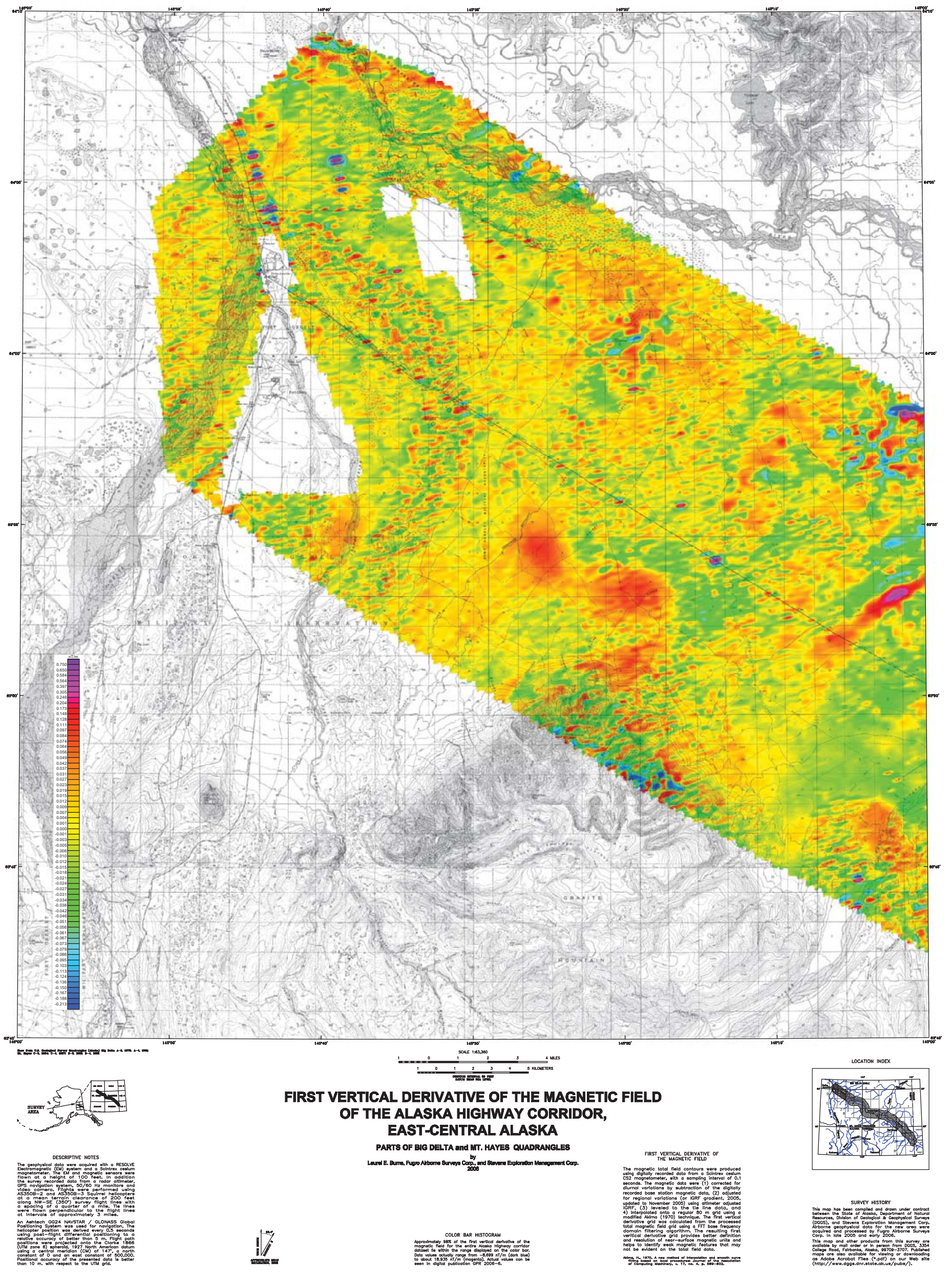









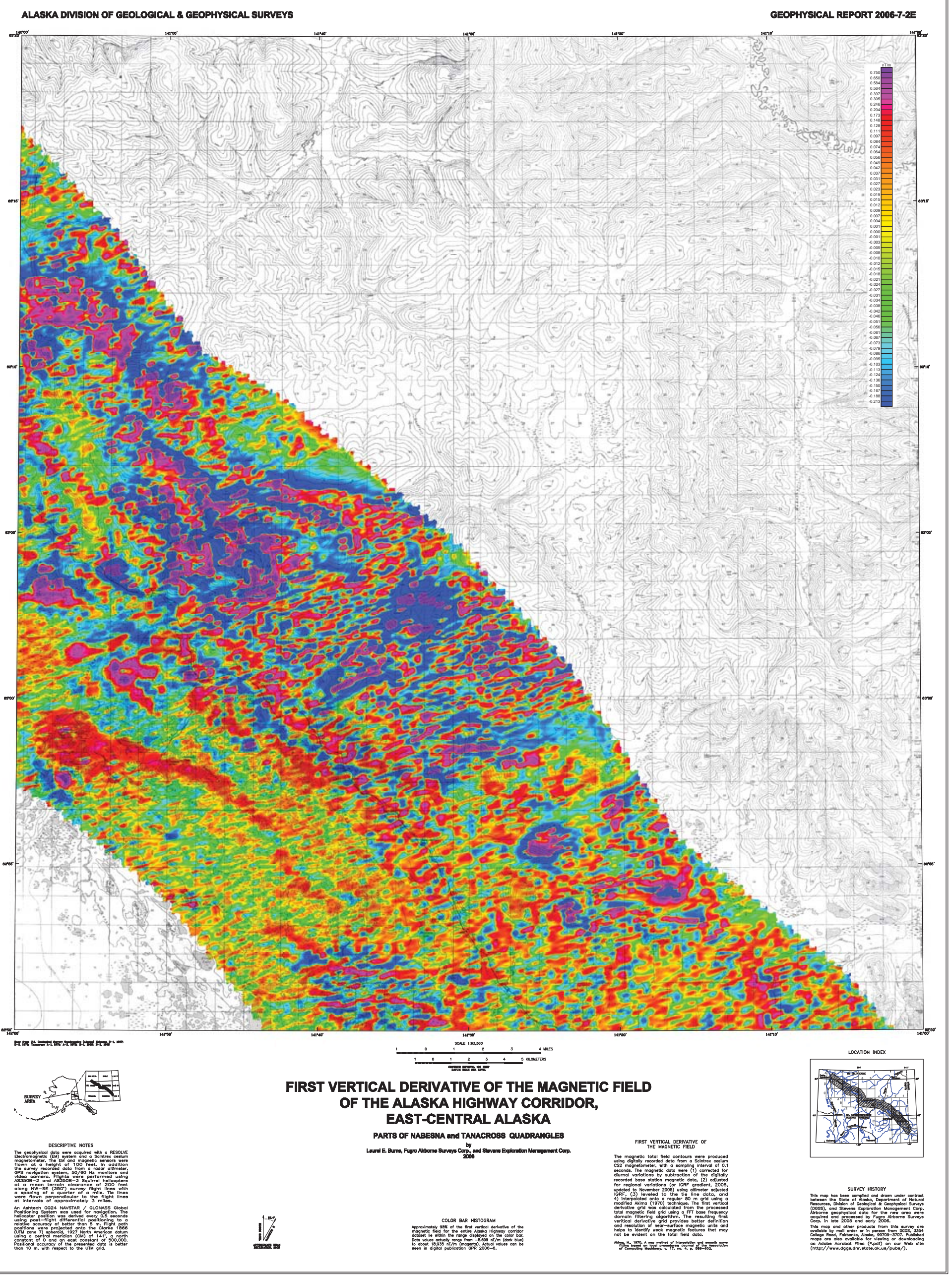




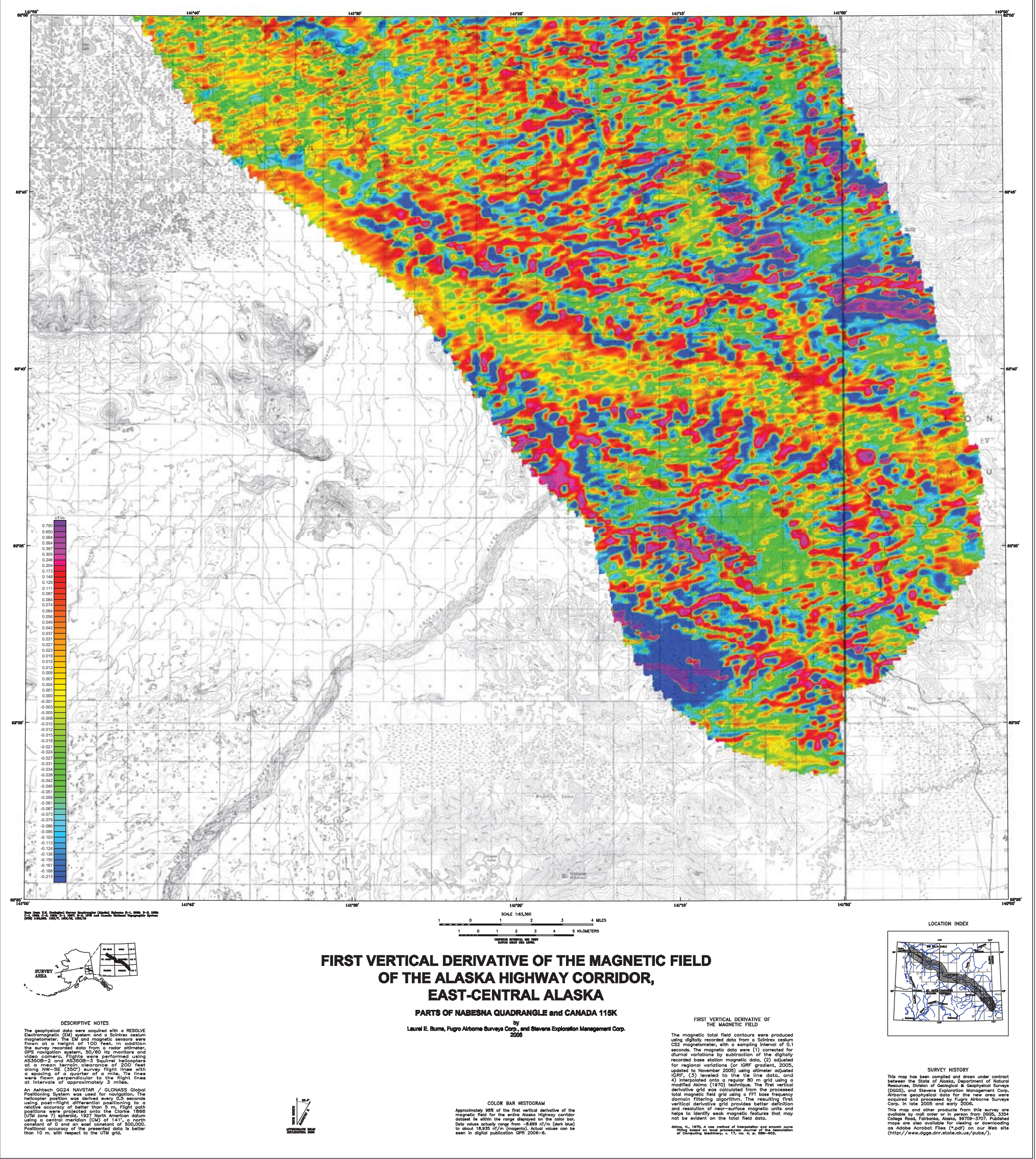




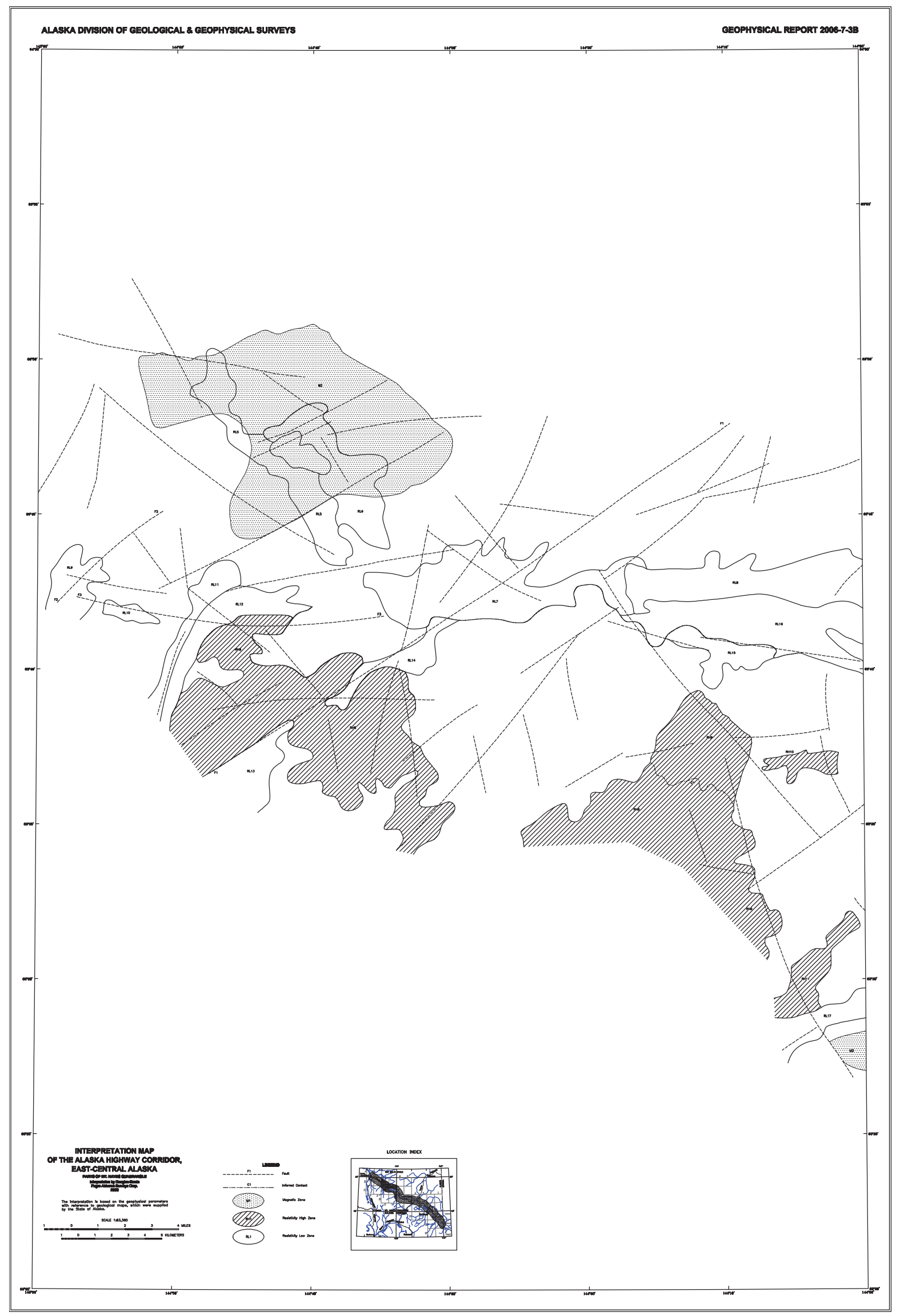









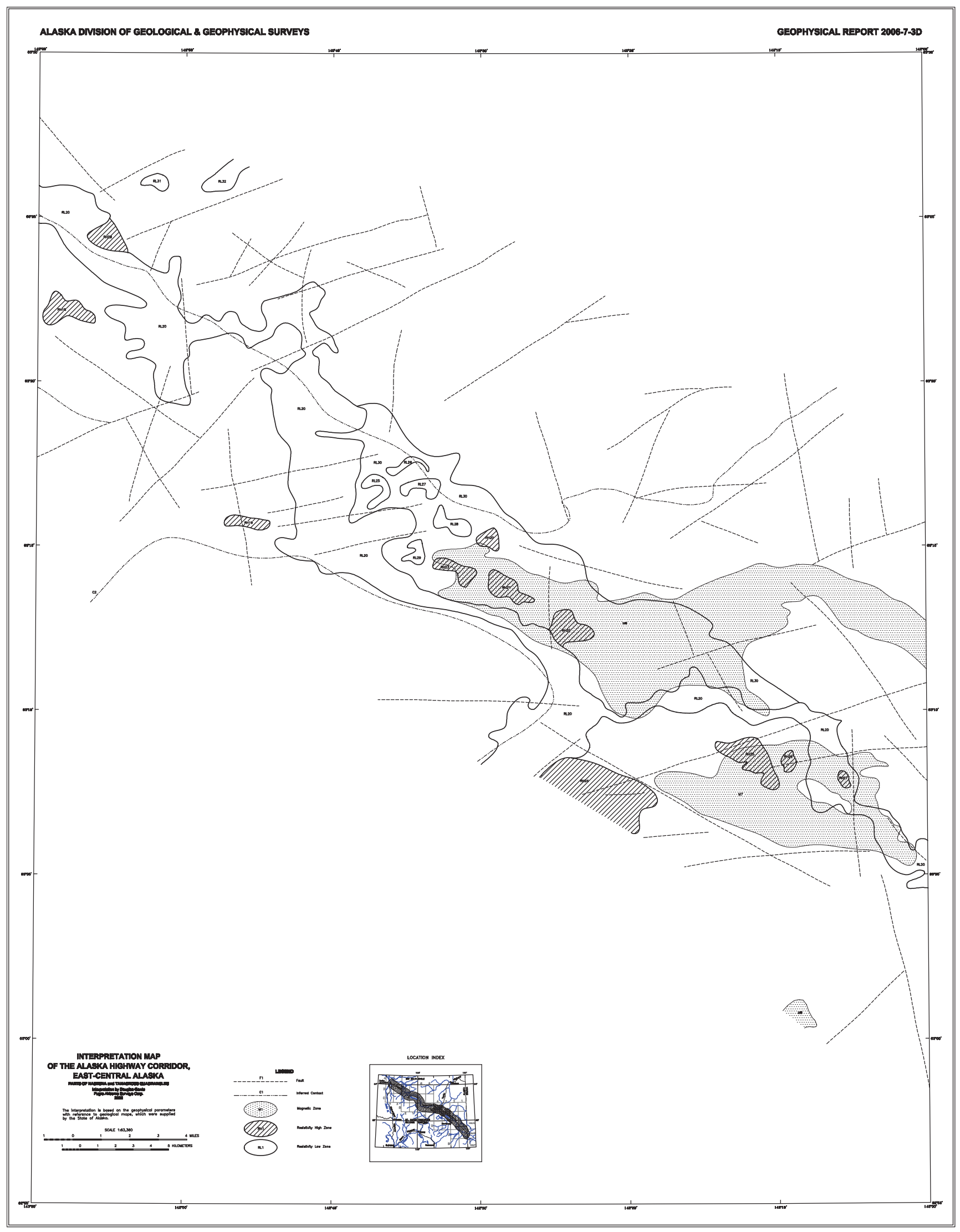




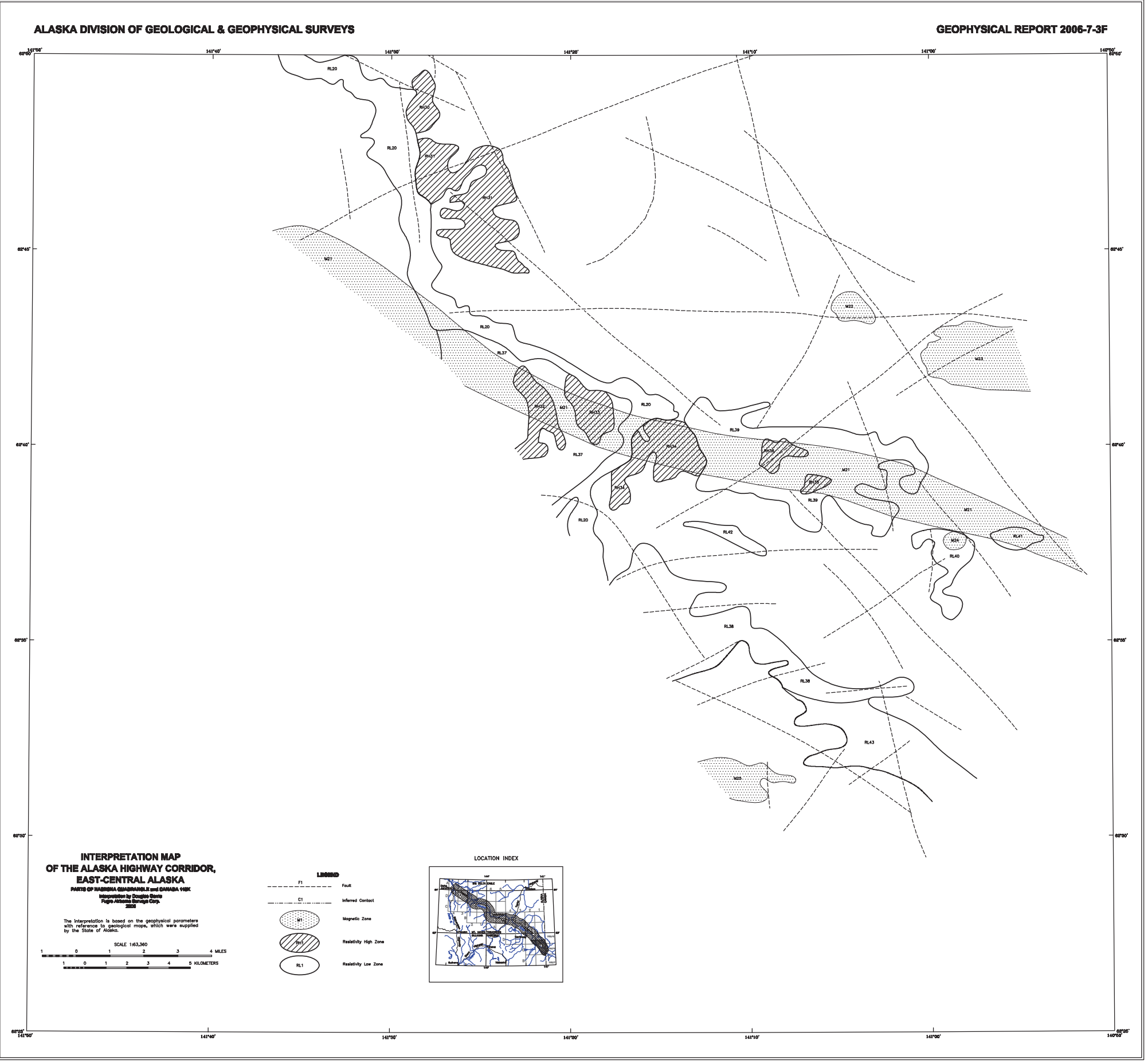

